\title{
CONCEPÇÕES E PRÁTICAS MATERNAS RELACIONADAS À CRIANÇA COM PNEUMONIA: ESTUDO REALIZADO NO MUNICÍPIO DE SÃO PAULO
}

Tese de Doutorado apresentada ao

Departamento de Saúde Materno-Infantil da Faculdade de Saúde Pública da Universidade de São Paulo para obtenção do Grau de Doutor.

Área de concentração: Saúde Materno-Infantil ORIENTADOR: PROF. DR. ALBERTO OLAVO ADVÍNCULA REIS

São Paulo

2003

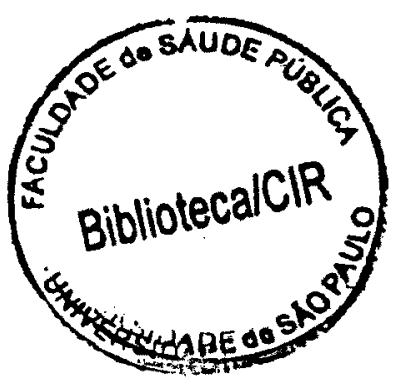




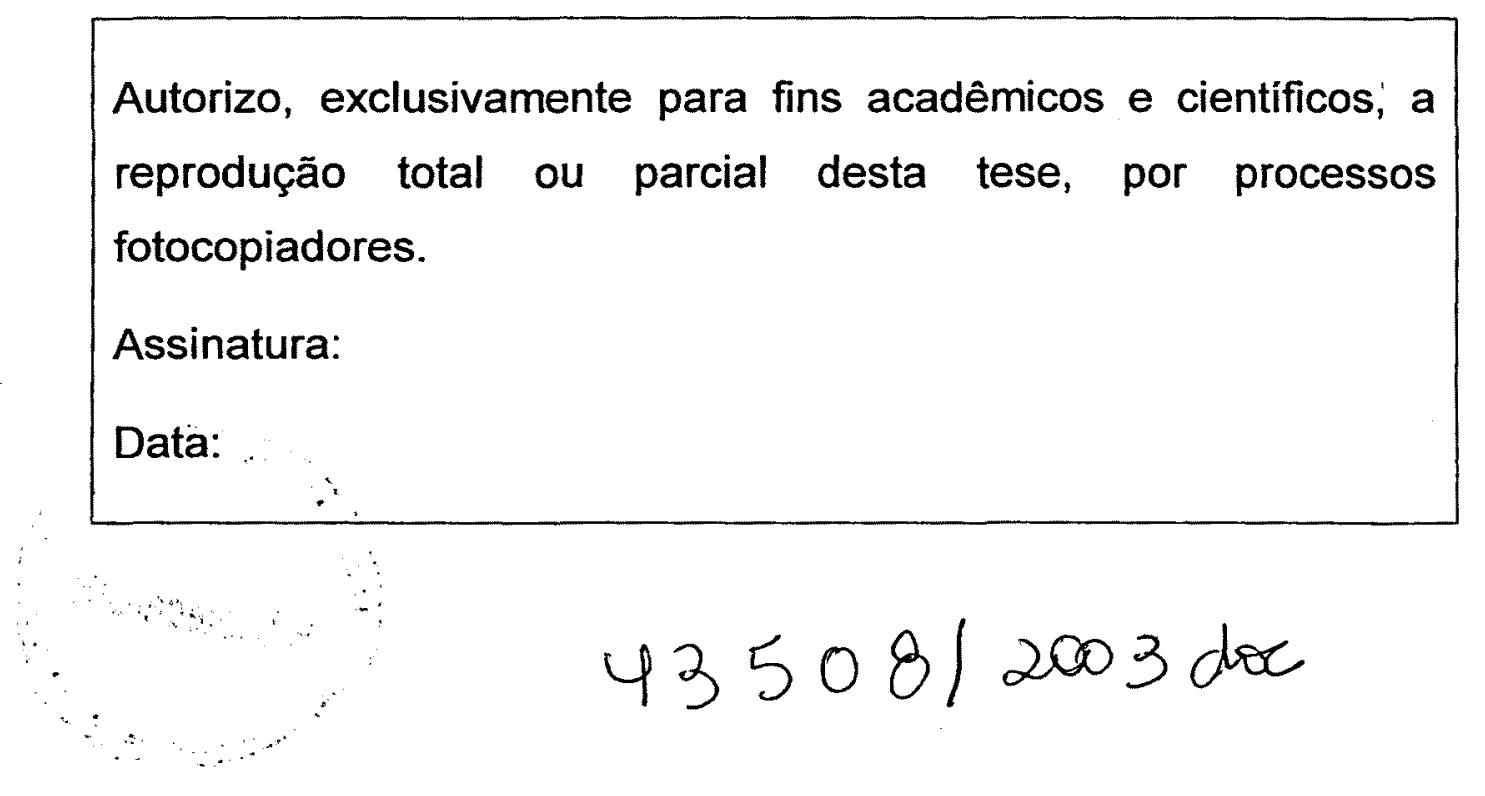


Aos queridos Juvenal, Camila e Eduardo, meu marido e nossos dois filhos, agradeço o imenso carinho a mim dedicado, por meio de apoio, estímulo e compreensão. 


\section{AGRADECIMENTOS}

No decorrer da elaboração deste trabalho, recebemos apoio e compreensão da parte de diversas pessoas, às quais retribuímos com sincera gratidão neste momento.

Ao Prof. Dr. Alberto Olavo Advíncula Reis, orientador e amigo, por suas fundamentais contribuições e, acima de tudo, pelo seu apoio e confiança.

Às mães, que confiaram a nós seus pensamentos e sentimentos por vezes intimos, por sua participação, sem a qual não seria possivel levar a cabo esta investigação.

Ao Centro de Saúde Escola "Prof. Samuel Barnsley Pessoa" da Faculdade de Medicina da Universidade de São Paulo, pela acolhida no desenvolvimento desta pesquisa.

À minha querida mãe, Helena, pelo estímulo e, principalmente, pelas horas de trabalho que passamos juntas.

Às queridas amigas e companheiras de trabalho, Magda Andrade Rezende, Maria De La Ó Ramallo Verissimo, Moneda Oliveira Ribeiro, Anna Maria Chiesa e Maria Rita Bertolozzi, pelas constantes manifestaçōes de apoio, compreensão e cooperação.

Às estudantes de enfermagem, Roberta Cristiane Pascarelli Alves e Acácia Hosotani Prado, pela disponibilidade e valiosa ajuda dispensada no decorrer deste trabalho. 
Aos funcionários do Departamento de Enfermagem MaternoInfantil e Psiquiátrico e do Departamento de Enfermagem em Saúde Coletiva da Escola de Enfermagem da USP e do Departamento de Saúde Materno-Infantil da Faculdade de Saúde Pública da USP, pelo apoio e colaboração.

Às bibliotecárias e demais funcionários da Biblioteca da Faculdade de Saúde Pública da USP e da Biblioteca da Escola de Enfermagem da USP, pela cooperação e solicitude. 


\section{RESUMO}

Sigaud CHS. Concepções e práticas maternas relacionadas à criança com pneumonia. São Paulo; 2003. [Tese de Doutorado - Faculdade de Saúde Pública da USP].

As infecções respiratórias agudas (IRA), em particular a pneumonia, ocupam posição de destaque no perfil de morbi-mortalidade infantil em nosso meio. Considerando que a maioria dos casos de IRA, exceto os severos, são tratados em casa e que as crenças e o cuidado domiciliar são vitais para o manejo da criança, esta tese teve como objetivo compreender as concepções e práticas maternas relativas à criança com pneumonia. Para tanto, realizou-se estudo de natureza qualitativa e constituíram-se sujeitos 20 mães cujos filhos recebiam atendimento de saúde em unidade básica situada no município de São Paulo. O material estudado foi obtido por entrevistas individuais e semi-estruturadas, realizadas pela pesquisadora. Para o tratamento dos dados, empregou-se o método de análise de conteúdo, segundo a técnica de análise temática. Os resultados evidenciaram uma compreensão materna limitada, confusa e vaga acerca da pneumonia, reunindo elementos provenientes do atual modelo biomédico de assistência à saúde ao lado de outros oriundos do senso comum. Com base nessa percepção, as práticas de saúde são orientadas para os aspectos biológicos da doença e de cunho curativo, embora sejam pouco efetivas muitas vezes. Em se tratando de usuários de serviço de saúde, a conduta materna revelou-se fortemente influenciada pelas práticas médicas, observando-se desvalorização das práticas populares por elas conhecidas. Diante desses resultados, ressalta-se a importância dos profissionais de saúde conscientizarem-se da estreita relação entre as concepções acerca da pneumonia e as práticas maternas dirigidas à criança doente. Nesse sentido, a presente investigação oferece contribuições que subsidiam a atuação dos trabalhadores de saúde para melhor compreender e intervir na realidade, transformando-a se possivel. 
Descritores: Saúde Infantil. Pneumonia. Infecções Respiratórias. Conhecimentos, Atitudes e Prática. 


\section{SUMMARY}

Sigaud CHS. Concepções e práticas maternas relacionadas à criança com pneumonia [Conceptions and maternal practices related to child with pneumonia]. São Paulo (BR); 2003. [Tese de Doutorado - Faculdade de Saúde Pública da Universidade de São Paulo].

Acute respiratory infections (ARI), especially pneumonia, have a distinguished position in infantile morbidity and mortality profile in our world. Considering that most of ARI cases, except for severe ones, are treated at home and that beliefs and family care are vital to deal with the child, this thesis had the objective to understand conceptions and maternal practices related to child with pneumonia. Thus, a qualitative study was conducted with 20 mothers whose children received health assistance in a basic unit located in the city of São Paulo. The studied material was obtained by means of individual and semi-structured interviews performed by the researcher. For analysis of data, the method of content analysis was used according to the thematic analysis technique. The results showed a limited, confused and vague maternal understanding of the pneumonia, gathering elements from the biomedical actual model of health assistance and others from common sense. Based on this perception, health practices are oriented towards biological and treatment aspects of the disease although many times not much effective. Regarding users of the health service, the maternal behavior denoted to be strongly influenced by medical practices, showing devaluation of popular practices known by them. In face of these results, the importance of health professionals in acknowledging the straight relationship between conceptions on pneumonia and maternal practices for the sick children is then emphasized. Based on this statement, the present investigation offers contributions which aid health professionals in their acting to better understand and intervene in the reality transforming it whenever possible. 
Descriptors: Child Health. Pneumonia. Respiratory Tract Infections. Knowledge, Attitudes, Practice. 


\section{ÍNDICE}

1 INTRODUÇÃO

1.1 As infecções respiratórias agudas no panorama de atenção à 1 saúde infantil no Brasil

1.2 A pneumonia infantil à luz das ciências biomédicas

1.3 Conhecimentos maternos e práticas de cuidado domiciliar no controle das infecções respiratórias agudas na infância e a educação em saúde

2 OBJETIVOS 16

2.1 Objetivo geral 16

2.2 Objetivos específicos 16

3 PERCURSO METODOLÓGICO 17

$\begin{array}{ll}3.1 \text { Tipo de estudo } & 17\end{array}$

3.2 Sujeitos e local do estudo 20

3.3 Obtenção dos discursos das mães 23

3.4 Procedimento de análise do material obtido 28

4 COMPREENDENDO OS DIRCURSOS MATERNOS 31

4.1 Cenário do estudo 32

4.1.1 A região do Butantã 32

4.1.2 O Centro de Saúde Escola "Prof. Samuel Barnsley Pessôa" $\quad 35$

4.2 Caracterização dos sujeitos do estudo 39

4.3 Categorias de análise $\quad 52$

4.3.1 Concepções da pneumonia em crianças 53

4.3.2 Práticas de cuidado materno relacionadas à criança com 97 pneumonia

6 REFERÊNCIAS BIBLIOGRÁFICAS 147 ANEXOS

Anexo 1 - Roteiro da Entrevista

Anexo 2 - Termo de Consentimento Livre e Esclarecido 


\section{INTRODUÇÃO}

\subsection{As infecções respiratórias agudas no panorama de atenção à saúde infantil no Brasil}

As infecçōes respiratórias agudas (IRA) têm elevada incidência na população infantil. Em revisão da literatura realizada por Graham (1990), os dados encontrados referentes à incidência do problema em crianças menores de cinco anos, residentes em centros urbanos, variam entre 4,5 e 7,9 episódios de doença ao ano. Embora existam poucas informaçōes que permitam estimar a importância das IRA como causa de doença infantil em países em desenvolvimento, estudos indicam que não há acentuadas diferenças quando comparados aos países desenvolvidos (Benguigui 1998).

Abre-se aqui, um parêntese para explicar que no presente estudo a expressão "paises em desenvolvimento" é usada para designar aqueles países que vêm apresentando melhoria em alguns de seus indicadores, como por exemplo, os de saúde sem, contudo, significar que o pais como um todo esteja se desenvolvendo.

Dada sua importância em termos da freqüência de ocorrência dos agravos na população infantil, de acordo com Benguigui (1997), as IRA se constituem principal causa de consulta em serviços de saúde em nível primário de atenção (de 4 a 6 consultas/ano), especialmente nos meses frios, chegando a totalizar entre 40 e $60 \%$ dos atendimentos. Além disso, representam o principal motivo de administração de medicamentos às crianças, especialmente os antibióticos, que na maioria das vezes são desnecessários e até prejudiciais.

A maioria das IRA, segundo Antuñano (1998), corresponde a "infecções virais das vias respiratórias altas que em geral são auto-limitadas e curam espontaneamente com cuidados caseiros". Apenas uma pequena parcela dos agravos corresponde a casos graves, como pneumonia e 
bronquiolite que acometem com maior freqüência as crianças de pouca idade. Contudo, nestes casos, tais agravos se constituem como os principais responsáveis pelos óbitos infantis de causa respiratória.

Dentre as mortes infantis por IRA nas Américas, aproximadamente $90 \%$ são devidas à pneumonia e $99 \%$ destes casos ocorrem nos paises em desenvolvimento (Antuñano 1998). Anualmente, cerca de 150.000 crianças menores de 5 anos morrem por pneumonia nesta Região, colocando esta doença entre as cinco principais causas de morte infantil em todos os países e chegando a ocupar o primeiro lugar em alguns deles (Benguigui 1997).

Analisando os dados de morbidade e mortalidade infantil por IRA dos vários paises, Graham (1990) sugere que o elevado número de óbitos por esta causa nos países em desenvolvimento se deve à maior proporção de casos graves (especialmente pneumonia) encontrada neles, uma vez que a incidência de IRA é semelhante em todos os países. Yunes e Diaz (1997) acrescentam, ainda, que tais índices de mortalidade decorrem da acentuada desigualdade social existente nos paises em desenvolvimento e de seu impacto nas condições de saúde da população.

De acordo com o documento Mortalidade Brasil: 1995 (Ministério da Saúde 1998), as doenças do aparelho respiratório ocupam terceiro lugar entre as principais causas de morte em menores de cinco anos (11.024 óbitos) no território nacional, seguindo as afecções originárias no período perinatal e as doenças infecciosas e parasitárias. No grupo de um a quatro anos de idade, as respiratórias assumem o primeiro lugar entre as causas de morte. Vale destacar que são observadas diferenças importantes no que diz respeito à mortalidade em crianças nas várias regiões do país.

Ainda segundo a mesma fonte literária, no Estado e Município de São Paulo, as doenças respiratórias se constituem como a segunda causa de óbitos no grupo etário de menores de cinco anos (2882 e 1066 mortes respectivamente), sendo precedidas apenas pelas afecções perinatais. Novamente, observa-se que, entre as crianças de 1 a 4 anos, este conjunto de causas ocupa o primeiro lugar. 
Os dados acima descritos demonstram a importância das causas respiratórias no cenário de mortalidade infantil tanto em âmbito nacional, quanto estadual e municipal de São Paulo. No conjunto das doenças do aparelho respiratório, a pneumonia é a mais importante, respondendo por $70-80 \%$ das mortes infantis nas diferentes instâncias.

Como um reflexo de sua elevada freqüência de ocorrência e do contigente de casos graves, as IRA acabam também por constituir-se a principal causa de hospitalização infantil (de 20 a $40 \%$ das internações) nos países em vias de desenvolvimento das Américas (Benguigui 1998).

Em virtude da importância que as IRA, particularmente as pneumonias, assumem enquanto causa de adoecimento e morte entre as crianças menores de 5 anos, em 1984 o Ministério da Saúde do Brasil publicou a primeira versão das normas para controle e assistência das infecçōes respiratórias agudas, já incorporadas ao conjunto de ações que compunham o Programa de Atenção Integral à Saúde da Criança - PAISC, tendo sido realizadas diversas revisões do material posteriormente (Ministério da Saúde 1994).

Em 1996, visando alcançar um maior impacto sobre a mortalidade e morbidade infantil pelas doenças prevalentes nos países em desenvolvimento (entre elas as IRA e particularmente as pneumonias), a Organização Panamericana da Saúde e a Organização Mundial da Saúde, junto com o Fundo das Nações Unidas para a Infância (UNICEF) apresentaram a estratégia de Atenção Integrada às Doenças Prevalentes da Infância (AIDPI), que compreende as açōes de controle destes problemas que já se vem executando (Benguigui 1997). Desde então a OPAS/OMS vem se dedicando à difusão desta estratégia visando sua implementação.

Conforme o documento "Apresentação e análise do curso sobre Atenção Integrada às Doenças Prevalentes da Criança - versão preliminar" (OPAS/OMS/UNICEF 1996), tal proposta se vale de um conjunto de critérios de avaliação, classificação e tratamento dos casos, podendo ser aplicado por profissional de saúde médico e não-médico no nivel primário de atenção. 
A estratégia AIDPI tem como objetivos gerais: reforçar o conceito de integridade da atenção da saúde da criança nos serviços de saúde; fortalecer a capacidade de planejamento e resolução do nivel primário de atenção; e alcançar uma maior equidade no acesso à atenção adequada à saúde da criança. E específicos: a redução da mortalidade pelas doenças prevalentes em crianças menores de cinco anos; a redução da ocorrência e gravidade dos casos; e a melhoria da qualidade de atenção prestada nos serviços de saúde (Benguigui 1997).

Por seu caráter integrado, a estratégia AIDPI permite identificar problemas que não tenham sido o motivo da procura do serviço reduzindo desse modo, as oportunidades perdidas de deteç̧ão precoce de doenças. Inclui ainda ações de vigilância à saúde, tais como avaliação da situação vacinal e do estado nutricional infantil, bem como apresenta um componente educativo de promoção à saúde, que visa melhorar as práticas de cuidado da criança no domicílio.

Foi elaborada com base em conhecimentos atualizados sobre as enfermidades que mais afetam as crianças menores de 5 anos, sendo selecionados para avaliação dos casos, os sinais e sintomas que têm maior valor preditivo para detecção precoce dessas doenças.

A proposta em questão tem sido considerada a intervenção capaz de produzir maior impacto na redução da carga global de doença, incapacidade e morte infantil, como também a de melhor relação custo-benefício nos países de baixa e média renda. Por esta razão, com o apoio de organismos e agências internacionais, os representantes dos paises em desenvolvimento das Américas, inclusive o Brasil, vêm envidando esforços no sentido de implementá-la, visando o cumprimento das metas da Cúpula Mundial em Favor da Criança.

Entretanto, para lograr o controle das IRA é imprescindivel que as famílias desempenhem seu papel adequadamente no cuidado das crianças doentes em casa, através do reconhecimento precoce do problema e busca oportuna de atenção em serviço de saúde, bem como da realização de 
tratamento adequado, prevenindo assim, complicações e até mesmo casos de morte por causas respiratórias.

Para tanto, é necessário compreender o conjunto de conhecimentos, motivações e comportamentos relacionados à saúde para que se possa atuar na comunidade. As atividades educativas da população têm que ser sensiveis à linguagem e cultura popular, como também às práticas de cuidado domiciliar. Deve-se dar ênfase às formas de capitalizar as ações adequadas de cuidado domiciliar à criança e, ao mesmo tempo, desencorajar o uso de condutas impróprias e, às vezes, perigosas. 


\subsection{A pneumonia infantil à luz das ciências biomédicas}

Conforme já foi exposto anteriormente, de um modo geral, as IRA compreendem uma gama de afecções que acometem o trato respiratório e apresentam elevada incidência na população infantil. Aquelas que afetam as vias aéreas superiores respondem pelos numerosos casos de morbidade, enquanto que os óbitos são atribuídos a outras, que acometem as estruturas inferiores do aparelho respiratório. Dentre estas últimas, a pneumonia assume o primeiro lugar entre as causas de morte por doenças do aparelho respiratório em crianças.

A literatura básica da área de saúde não pode se esquivar da abordagem das infecções respiratórias agudas, dada a importância que assume no perfil de morbi-mortalidade da população infantil nos países menos desenvolvidos. Entre estas enfermidades, a pneumonia tem sido objeto de muitos estudos em razāo da posição de destaque que ocupa no conjunto das entidades mórbidas do grupo pediátrico, em termos da freqüência e gravidade de que se acompanha. Assim sendo, segue um arrazoado sucinto relativo a enfermidade em questão, bem como referente aos cuidados realizados no domicílio junto à criança doente.

Segundo Rozov (1987), broncopneumonias e pneumonias são "processos inflamatórios, geralmente agudos, comprometendo alvéolos, bronquíolos e espaço intersticial, que adquirem características diferentes conforme o agente etiológico, idade do paciente, doença de base e seu estado nutricional e imunitário".

Geralmente o processo patogênico se desenvolve a partir da entrada do agente bacteriano pelas vias aéreas, atravessando os brônquios e localizando-se nos bronquíolos e alvéolos, onde produzem uma série alterações caracterizando um processo inflamatório. Tal processo pode se manter restrito a um segmento ou lobo pulmonar, denominando-se pneumonia lobar, ou se estender a pontos distantes, desrespeitando a 
segmentação do pulmão, sendo chamado de broncopneumonia (Gomes e Valente 1999).

As pneumonias podem ser de múltiplas origens entre elas a bacteriana, a viral, a micótica e a protozoótica. Contudo, nos países em desenvolvimento, verificou-se que há predomínio da etiologia bacteriana com base em pesquisas feitas em material pulmonar colhido por técnica de aspiração transcutânea e hemoculturas (Ruvinsky e Balanzal 1998).

De acordo com Urday et al. (2001), estudos sobre etiologia bacteriana de pneumonia na infância realizados em paises em desenvolvimento encontraram praticamente os mesmos resultados. As bactérias predominam como agentes etiológicos da pneumonia adquirida na comunidade, entre elas Streptococcus pneumoniae e Haemophilus influenzae são as mais comuns.

Em ensaios terapêuticos e trabalhos acerca do diagnóstico etiológico da pneumopatia aguda em crianças brasileiras, levantados na literatura por Rozov (1987), o S. pneumoniae é apontado como o microrganismo mais importante nos processos agudos adquiridos na comunidade, inclusive entre lactentes pequenos.

Pesquisa realizada na cidade de São Paulo, com crianças hospitalizadas com diagnóstico de pneumonia aguda não complicada, confirmou etiologia predominantemente bacteriana (Ejzenberg et al. 1986). Foram identificadas infecções bacterianas em aproximadamente $60 \%$ dos pacientes, sendo $S$. pneumoniae e $H$. influenzae as bactérias mais encontradas, que isoladamente ou em associação, foram responsáveis por quase $70 \%$ dos casos. Essas bactérias foram detectadas nas várias faixas etárias pediátricas, revelando-se em primeiro lugar em todas elas.

Conforme documento da OPAS/OMS (1985), o S. pneumoniae se encontra no trato respiratório superior das crianças em geral, mas mesmo assim a pneumonia não é muito freqüente, graças ao antagonismo microbiano que atua limitando o crescimento do pneumococo, à dificuldade que a bactéria enfrenta para passar pela epiglote e à ação dos mecanismos 
de defesa pulmonar. $O$ desenvolvimento da doença está mais relacionado com a existência de fatores predisponentes do que com a exposição ao pneumococo.

Entre os fatores intrinsecos e extrínsecos que predispõem e agravam as pneumonias bacterianas, Rozov (1987) enumera desnutrição, sarampo, viroses, coqueluche, mucoviscidose, bronquite e bronquiectasia, corpo estranho, malformações pulmonares e torácicas, cardiopatias congênitas com fluxo pulmonar aumentado, encefalopatias, condições que implicam imunodepressão e imobilidade.

Desde o surgimento dos antibióticos, a mortalidade produzida por $S$. pneumoniae foi reduzida drasticamente. De acordo com Urday et al. (2001), os antibióticos se constituem o principal recurso terapêutico para o controle das infecções respiratórias bacterianas até o presente momento. Dentre eles, a penicilina é a droga antimicrobiana de eleição para o tratamento da pneumonia pneumocócica, já tendo sido demonstrado o desenvolvimento de resistência por parte do microrganismo a alguns medicamentos, inclusive este.

A determinação do agente etiológico da pneumonia é importante para a correta indicação da terapêutica, permitindo decidir pela administração ou não de antibiótico, bem como orientando a escolha do mais adequado quando se aplicar. Entretanto, tal tarefa é tecnicamente difícil, sendo o problema ainda maior em locais onde não se dispõe de laboratórios devidamente equipados. Rozov (1987) chama atenção para o fato de que menos de $5 \%$ das crianças com patologias das vias respiratórias inferiores no Brasil têm o diagnóstico etiológico da doença. Outro dado a ser levado em conta é a elevada freqüência de etiologias mistas.

Sendo assim, para definir o diagnóstico e a conduta terapêutica o profissional que atende crianças deve orientar-se por achados clínicos em primeira mão e, quando possivel e necessário, utilizar-se de exames laboratoriais e radiológicos, relacionando-os com as características infantis e a situação epidemiológica. 
$\mathrm{Na}$ atualidade, o método de diagnóstico mais difundido na prática médica requer ambas as evidências, clínica e radiológica. Entretanto, Gomes e Valente (1999) salientam que somente metade dos casos clínicos apresenta alterações na radiografia de tórax e aproximadamente $30 \%$ das pneumonias são assintomáticas do ponto de vista clínico.

O protocolo da OPAS/OMS para o manejo padrão de casos de IRA incorporado pela estratégia AIDPI recomenda a utilização dos sinais clínicos respiração rápida e tiragem subcostal para identificar as crianças que têm pneumonia entre as que têm tosse ou dificuldade para respirar (Benguigui 1997).

Segundo Ruvinsky e Balanzal (1998), diversos estudos mostraram através de dados empíricos a taquipnéia e a tiragem subcostal como os sinais de maior valor preditivo para a pneumonia, pautados nos aspectos de especificidade e sensibilidade dos mesmos.

A definição de freqüência respiratória aumentada varia de acordo com a idade, levando em conta que os valores normais diminuem com o avanço da idade. Assim, na criança de 2 a 11 meses de idade, considera-se que ela tem pneumonia quando apresenta 50 ou mais respirações por minuto, e 40 ou mais se ela tem de 1 a 4 anos. A presença de tiragem subcostal é tomada como sinal de pneumonia grave para crianças de 2 meses a 4 anos de idade.

$O$ tratamento medicamentoso preconizado restringe-se ao uso de antibióticos e de drogas sintomáticas para controle da febre (antitérmicos) e da dor (analgésicos), quando necessário. Além destes, podem ser usados preparados caseiros para alívio da tosse e da irritação das mucosas, como chás e xaropes à base de produtos naturais, entre eles mel, limão, folhas de boldo, poejo, agrião, hortelã, etc.

Graças à antibioticoterapia, a mortalidade por pneumonia sofreu drástica redução, passando de 30-50\% para $15 \%$, segundo Rozov (1987). Entretanto, ainda podem ocorrer complicações, que no caso da pneumonia pneumocócica são a otite média, a sinusite e a meningite. Lactentes 
pequenos e crianças que apresentam fatores predisponentes são os casos de pior prognóstico.

Cuidados gerais à criança doente podem ser realizados no âmbito domiciliar, contribuindo de forma significativa para a promoção à saúde, prevenção e recuperação dos agravos respiratórios na infância. Estas ações devem ser pensadas em particular para a situação de cada criança e familia. Dentre elas, de acordo com Veríssimo e Sigaud (2001), encontram-se medidas voltadas a: prevenção da disseminação da infecção ou proteção da criança contra novas contaminações; controle da dor; manutenção da alimentação; estimulação da hidratação; prevenção da desidratação; fluidificação, mobilização e remoção de secreções nasais e pulmonares; identificação de sinais de gravidade para busca de atenção em serviço de saúde; aleitamento materno e imunizações; e cuidados de higiene ambiental. 


\subsection{Conhecimentos maternos e práticas de cuidado domiciliar no controle das IRA na infância e a educação em saúde}

O papel que desempenham as familias no que diz respeito à saúde da criança é da maior importância, tanto por terem ao seu encargo o cuidado e atenção da criança no domicilio, como também por definirem quando ela está doente e que atitudes e ações devem assumir frente ao problema. As decisōes envolvem desde entender que a doença requer busca de atendimento em serviço de saúde, até cumprir ou não as recomendações que o pessoal de saúde faz à familia para o tratamento e cuidado da criança em casa.

A percepção que a família tem dos sinais de doença da criança determina a precocidade da consulta a um serviço de saúde e tem uma grande influência na freqüência de aparição de casos graves de doença, na maioria das vezes associados à demora no início do tratamento e à ocorrência de mortes domiciliárias nos casos mais extremos. A conduta familiar com relação às recomendações de tratamento que o pessoal de saúde oferece no atendimento infantil também tem uma importância fundamental na evolução da doença da criança e, portanto, na proporção de casos curados e de complicações.

Entretanto, em ambos os casos, numerosos fatores relacionados com a organização e as características da atenção prestada nos serviços de saúde influem na conduta dos pais. Por vezes, a população não dispõe de serviços de saúde próximos onde possa ser atendida quando a criança está doente, não dispõe de meios de transporte eficientes, nem de recursos financeiros suficientes para custear tanto um como outro. Outras vezes, a população não busca os serviços precocemente devido a dificuldades vivenciadas em atendimentos prévios, tais como espera prolongada ou tratamento inadequado. 
Além destes fatores, encontram-se outros associados à falta do cumprimento das recomendações oferecidas pelo pessoal de saúde, entre eles os conhecimentos, atitudes e práticas dos profissionais que prestam atendimento à comunidade. Na prática cotidiana dos serviços de saúde não se dá o devido valor à relação estabelecida entre o pessoal do serviço de saúde e a clientela, nem às atividades educativas.

Neste sentido, muitas vezes a informação oferecida não é adequada e, principalmente, a forma como é compartilhada com a família é imprópria. A inadequação da forma se faz presente seja porque é utilizada linguagem técnica, seja porque não se dá oportunidade aos pais de se expressarem, impedindo-lhes de tirar suas dúvidas e discutir suas dificuldades para o cumprimento das recomendações.

De acordo com Chiesa e Veríssimo (2001), uma nova prática educativa baseia-se em novas bases conceituais. Incorpora os conceitos de "empowerment" ou fortalecimento pessoal, entendido como um processo de desenvolvimento pessoal ou ampliação do poder político, e de participação comunitária. Pressupõe-se que os indivíduos possam ampliar o controle sobre suas vidas promovendo transformações das realidades social e política e, desse modo, esta abordagem se diferencia do modelo tradicional centrado na mudança de comportamento.

Nessa outra perspectiva educacional, as ações assumem um caráter mais abrangente, destacando-se o direito à saúde e a capacidade de escolha dos indivíduos. Nela, a comunicação ocupa posição central, pois é o meio de veiculação do processo educativo. A base do processo comunicativo é o conhecimento recíproco entre usuários e trabalhadores da saúde. A partir da troca de informações, crenças e valores, pretende-se "chegar a acordos que orientem positiva e efetivamente os fazeres dos profissionais e usuários para o atendimento às necessidades de saúde destes últimos" (Chiesa e Veríssimo 2001, p.36).

Assim sendo, para se produzir ações de maior impacto no campo da saúde infantil, é fundamental que os profissionais encarregados do 
atendimento estejam atentos ao processo de comunicação que se estabelece com a familia e aos vários aspectos envolvidos nele.

Neste contexto, a importância das crenças e práticas culturais para maior efetividade das ações básicas de saúde tem sido mais e mais reconhecida (Chevallier 1993). Os conhecimentos e crenças da família sobre saúde, bem como seus costumes e práticas relacionados ao cuidado dos filhos condicionam a abordagem e tratamento da criança doente. Crenças e práticas que atravessam gerações determinam em grande medida a forma como o grupo familiar concebe um determinado problema de saúde. A dinâmica da própria família associada às concepções culturais e sociais sobre criação das crianças também determina os cuidados.

Charaly (1998), discutindo os resultados de estudo etnográfico realizado na Bolívia sobre conhecimentos, atitudes e práticas relacionadas às IRA em crianças, aponta sua importância no sentido de orientar apropriadamente o desenvolvimento do Programa de controle das IRA. Tal investigação permitiu aos trabalhadores de saúde conhecerem os termos locais a respeito dos sinais de pneumonia e as práticas de cuidado no domicilio, bem como identificarem os fatores que interferem na busca de atenção à criança com IRA. Assim, foi possível estabelecerem uma comunicação efetiva com as mães de crianças adequando as recomendações gerais.

Assim, considerando que a maioria dos casos de IRA, exceto os severos, são tratados em casa e as práticas de cuidado domiciliar são vitais para o manejo da criança com IRA, a mortalidade e morbidade por IRA poderiam sofrer reduções substanciais com a implementação de atividades educativas em saúde, que, por sua vez, só seriam efetivas se baseadas na compreensão acurada das concepções, atitudes e práticas da população.

Diferentemente das práticas domiciliares de atenção à saúde da criança com diarréia (basicamente a terapia com os sais de reidratação oral), que podem por si só reduzir a mortalidade por esta causa, as ações de controle das IRA exigem que os responsáveis pela criança saibam quando 
buscar atenção nos serviços de saúde. Muitos óbitos terminam por ocorrer porque as crianças são levadas tardiamente, ou sequer são levadas, a um serviço de saúde. Conforme Benguigui (1997), para que o programa de tratamento seja eficaz, é preciso que "as mães reconheçam os sinais clínicos de pneumonia, que estejam motivadas para buscar atenção de saúde apropriada fora de casa e que ministrem a dosagem completa de antibióticos. As mães não deverão esperar do tratamento com antibiótico uma cura imediata, e deverão saber que têm que voltar com a criança ao serviço de saúde se esta não melhorar, ou se piorar".

Voltados à finalidade de aprofundar conhecimentos sobre as percepções de familiares sobre IRA e o cuidado realizado à criança doente em casa, foram conduzidas diversas investigações em diferentes regiões do mundo. Entretanto, a maioria delas foi desenvolvida em comunidades residentes em zona rural (Campbell et al. 1990; Aung et al. 1994; Hudelson et al. 1995; Teka e Dagnew 1995; lyun e Tomson 1996; Ryan et a 1996; Grace 1998; Maynard-Tucker 1998; Collett et al. 1999; Pebley et al. 1999), cuja cultura e organização social assumem características muito peculiares. Entre os trabalhos realizados em populações urbanas (Rodriguez et al. 1990; Toro et al. 1992; Denno et al. 1994; Amofah et al. 1995; Khan et al. 1995; Muhe 1996; Khamgaonkar et al. 1999), grande parte teve lugar em países africanos e asiáticos, revelando resultados pouco transponiveis à nossa realidade social e cultural.

Encontramos poucas publicações de estudos desenvolvidos em território nacional: a pesquisa de Mendes (1995) realizada em Londrina-PR, a de Chiesa (1999) no município de São Paulo, e a de Monteiro et al. (2002) em Natal-PA. Tratam-se de estudos comunitários abordando as afecções respiratórias infantis mais comuns no que diz respeito ao conhecimento e ao cuidado da criança doente no domicílio.

Tendo em vista o exposto, entendemos que há necessidade de serem desenvolvidas mais investigações em nossa realidade, destinadas à compreensão das concepções e práticas relacionadas às infecções 
respiratórias agudas em crianças a fim de subsidiar os programas de controle e as propostas de educação em saúde que visam a redução da morbi-mortalidade por estas causas. Considerando a amplitude e a riqueza de percepções existentes em nosso meio, os resultados obtidos por estas pesquisas talvez não possam ser generalizados, pois guardam relação estreita com a história de vida e posição social ocupada pelos sujeitos participantes da pesquisa. 


\section{OBJETIVOS}

\subsection{Objetivo geral}

Assim sendo, o presente estudo tem como objetivo geral compreender percepções das mães relacionadas à pneumonia e suas práticas domiciliares de cuidado da criança doente menor de cinco anos, pois esta é a faixa etária infantil de maior vulnerabilidade para a doença em questão. Tem-se uma preocupação especial quanto às formas mais graves de doença respiratória, entendendo que os casos graves têm maior probabilidade de morrer. Além disso, interessa-nos particularmente o comportamento da população no que diz respeito à busca de atenção à criança em serviço de saúde, uma vez que é decisiva para o diagnóstico e tratamento adequado do problema.

\subsection{Objetivos específicos}

A seguir, relacionamos os objetivos detalhados da pesquisa:

1. Compreender as concepções maternas acerca da pneumonia.

2. Compreender as concepções maternas relativas aos cuidados e tratamentos dispensados à criança no domicilio.

3. Compreender os conhecimentos maternos sobre os sinais de pneumonia ou doença respiratória que motivam a busca de atenção à criança em serviço de saúde. 


\section{PERCURSO METODOLÓGICO}

\subsection{Tipo de estudo}

A fim de viabilizar o alcance dos objetivos propostos, entendendo-se que o estudo das crenças pertence ao domínio das Ciências Sócias, mais especificamente ao campo da Psicologia Social, e que a compreensão destas é viável por meio do enfoque qualitativo, optou-se por desenvolver um estudo de natureza qualitativa. Minayo argumenta dizendo que "a realidade social (objeto especifico de conhecimento das Ciências Sociais) é o próprio dinamismo da vida individual e coletiva com toda riqueza de significados dela transbordante" (Minayo 1994, p.15) e, portanto, "esse objeto que é sujeito se recusa peremptoriamente a se revelar apenas nos números ou a se igualar com sua própria aparência" (Minayo 1992, p.36). Assim coloca-se ao pesquisador o desafio de ir em busca dos significados da ação humana que constrói a história.

A abordagem qualitativa tem o significado como sua preocupação essencial, conforme destaca Triviños (1992). Os investigadores estudam o que pensam os sujeitos acerca de suas experiências, de suas vidas, procurando identificar os significados que atribuem aos fenômenos. Respondendo questões muito particulares, a pesquisa qualitativa "trabalha com o universo de significados, motivos, aspirações, crenças, valores e atitudes, o que responde a um espaço mais profundo das relações, dos processos e dos fenômenos que não podem ser reduzidos à operacionalização de variáveis" (Minayo 1994, p.21 e 22).

O confronto entre "quantitativo" e "qualitativo" tem sua origem nas diferentes formas de perceber a realidade social. Conforme Minayo (1994, p.22), "enquanto cientistas sociais que trabalham com estatística apreendem dos fenômenos apenas a região 'visivel, ecológica, morfológica e concreta', a abordagem qualitativa aprofunda-se no mundo dos significados das ações 
humanas, um lado não perceptível e não captável em equações, médias e estatísticas".

Em verdade, não há oposição entre os dados de natureza quantitativa e qualitativa e sim complementaridade, pois oferecem aproximações da realidade que interagem dinamicamente.

A crítica que se faz em relação à quantificação da análise sociológica está no fato de restringir a realidade social ao que pode ser observado e quantificado apenas, desprezando aspectos essenciais desta realidade. Em nome da objetividade assegurada pelo uso de instrumentos padronizados e pretensamente neutros, têm sido sacrificados os significados e simplificada a vida social arriscando-se inferências que extrapolam os dados.

$\mathrm{Na}$ atualidade, a preocupação com os significados ganha força e são enfatizadas as correntes de pensamento que assumem o ser humano enquanto ator social como a essência da sociedade. Em oposição ao positivismo, a sociologia compreensiva propõe o sentido como o caráter definidor da ação social. A subjetividade é considerada como parte integrante da singularidade do fenômeno social e inerente à construção da realidade objetiva.

Desse modo, os investigadores lançam mão das metodologias qualitativas capazes de incorporar a questão do significado e da intencionalidade como inerentes aos atos, buscando compreender a dinâmica das relações sociais. Para tanto, estudam a vivência, o cotidiano e também, a compreensão das estruturas enquanto produto da ação humana. Nesta perspectiva, a linguagem, as práticas e as coisas são inseparáveis.

Martins e Bicudo (1989) resumem esta questão afirmando que a pesquisa qualitativa busca a compreensão das múltiplas relações e determinações de um fenômeno social. Visando a compreensão do fenômeno estudado, tem como foco de atenção algo que é específico, particular. Permite o "aclaramento" dos sentidos e significados presentes na comunicação dos sujeitos. 
No desenvolvimento dessa pesquisa, utilizamos um quadro interpretativo constituído pela congregação de diversos horizontes teóricos dentre os quais se destaca a Psicologia Social, sobretudo a Teoria das Representações Sociais. 


\subsection{Sujeitos e local do estudo}

Partimos do pressuposto que as percepções acerca da pneumonia e dos cuidados prestados à criança doente podem variar, entre outros fatores, devido às diferentes experiências pessoais dos sujeitos. Neste sentido, ter vivido ou não, a experiência de ter um filho acometido por pneumonia poderia contribuir para a (re)formulação de concepções acrescentando elementos referentes às práticas tradicionais de cuidado à criança enferma, transmitidas de geração a geração, como também recomendações oferecidas por profissionais de saúde, que tenham prestado atendimento infantil durante o episódio de doença.

Desse modo, constituíram o conjunto de sujeitos desta pesquisa vinte (20) mães que tivessem pelo menos um filho com idade entre 2 meses e 4 anos na ocasião. Tal delimitação etária está relacionada ao fato deste grupo populacional apresentar maior vulnerabilidade para adoecer e morrer por pneumonia e, por isso, constituir-se alvo da estratégia AIDPI. Exclui-se o segmento de menores de dois meses em função da doença se manifestar de forma muito peculiar no mesmo.

O conjunto de mães participantes deu origem, por assim dizer, a dois grupos de sujeitos: um formado por mães (14) cujos filhos não haviam contraido pneumonia até o momento da pesquisa; e outro, constituído por aquelas (6) que tinham vivido a experiência de ter ao menos um filho acometido de pneumonia nesta faixa etária.

Inicialmente, preconizou-se a proximidade do episódio de adoecimento infantil, devendo a ocorrência do mesmo ter se dados nos seis meses que antecederam a pesquisa. Tal preocupação deveu-se ao propósito de favorecer a memória dos fatos, enriquecendo os relatos maternos sobre as experiências vividas.

Entretanto, o trabalho de campo revelou ser esta uma exigência muito difícil de ser atendida, uma vez que as mães foram buscadas em uma 
unidade básica de saúde e os casos de crianças com história pregressa de pneumonia mostraram-se eventuais naquela comunidade.

Cabe lembrar que muito embora as IRA correspondam ao principal motivo de consultas pediátricas, a imensa maioria dos casos são de infecções de vias aéreas superiores. As infecções de trato respiratório inferior, entre elas as pneumonias, representam uma pequena parcela dos diagnósticos, estando sua relevância no fato de vigorarem entre as principais causas de óbitos infantis.

Assim, sendo a pneumonia um evento menos freqüente na população infantil atendida no serviço, encontrar mães de crianças com idade de 2 meses a 4 anos que tivessem sido acometidas por pneumonia nos últimos seis meses se constituiu uma dificuldade para o estudo. Por esta razão, este critério de inclusão dos sujeitos foi abolido. Na prática, isto significou que em dois casos a pneumonia havia ocorrido dois meses antes da pesquisa, em outro caso, sete meses atrás, e nos três restantes, antecedeu entre um ano e dois meses e dois anos.

A flexibilização do referido critério de inclusão pode ter provocado algum prejuizo quanto à memória dos participantes (por exemplo, não recordar o nome de uma droga administrada ao filho para o tratamento da pneumonia ou o nome de uma planta usada no preparo de um chá/xarope caseiro). No entanto, foi possivel observar se constituírem perdas pouco significativas para o estudo em questão. $E$ ainda, por outro lado, no decorrer da coleta de dados da pesquisa, constatou-se que o tempo contribuiu para a elaboração das vivências por parte das mães entrevistadas e, consequentemente, possibilitou uma melhor compreensão de sua experiência.

Desse modo, conclui-se que a modificação do projeto original relativa ao momento em que se deu o agravo infantil não trouxe repercussões negativas que pudessem ter comprometido a presente investigação.

Não fizeram parte da população estudada mães de crianças portadoras de determinadas condições de base associadas que poderiam 
demandar outros cuidados, tornando-se difícil fazer uma discriminação entre estes e aqueles acarretados pelo episódio de pneumonia. Entre estas condições ou doenças de base, foram consideradas: deformidades anatômicas do aparelho cárdio-respiratório, cardiopatia congênita, fibrose cistica, neuropatia e outros quadros que impliquem restrição à mobilidade, AIDS e outras situações causadoras de imunodeficiência.

Optou-se por buscar as mães participantes do estudo entre aquelas que levavam seus filhos para atendimento no Setor de Saúde da Criança do Centro de Saúde Escola "Prof. Samuel Barnsley Pessôa", da Faculdade de Medicina da Universidade de São Paulo, doravante referido por CSE. As mães foram acessadas na sala de espera do setor, enquanto aguardavam atendimento.

Tal decisão foi pautada em duas razões: por se tratar de estratégia para alcançar os sujeitos definidos para a pesquisa e também porque, nos últimos anos, a pesquisadora enquanto parte de um grupo de docentes da Escola de Enfermagem vem construindo um trabalho de articulação na área de atenção à saúde da criança junto a alguns profissionais do serviço, nas áreas de ensino, pesquisa e extensão universitária. Assim, a presente investigação constituiu-se mais uma contribuição nesse sentido.

A esse respeito, na análise e discussão do material foi levado em conta o fato das mães serem usuárias de serviço de saúde, o que certamente marcou suas concepçōes e práticas relacionadas à saúde/doença de seus filhos. Além disso, considerou-se que o CSE possui características particulares que o diferenciam dos serviços da rede de um modo geral, destacando-se pela qualidade do atendimento prestado à clientela, o que também pode ter imprimido certo direcionamento às entrevistas. 


\subsection{Obtenção dos discursos das mães}

A fim de obter dados para a realização do estudo, elegeu-se a técnica de entrevista por esta permitir a obtenção dos dados que interessam a esta investigação. Segundo Gil (1994, p.113), trata-se de uma técnica "bastante adequada para a obtenção de informações acerca do que as pessoas sabem, crêem, esperam, sentem ou desejam, pretendem fazer, fazem ou fizeram, 'bem como acerca de suas explicações ou razões a respeito das coisas precedentes".

É uma das técnicas de coleta de dados mais utilizadas nas pesquisas sociais, pois, conforme Minayo (1992), a fala é reveladora de condições estruturais, sistemas de valores, normas e símbolos, além de comunicar as representações de grupos determinados, em certas condições históricas, sócio-econômicas e culturais. Rimé (1986) a considera um instrumento privilegiado acrescentando que a linguagem se constitui numa determinada maneira de decodificar a realidade, refletindo e mantendo uma certa ordem ou estrutura social, por se tratar de produto histórico de uma coletividade, que existe independente do sujeito.

A fala do indivíduo é representativa do pensamento social, na medida em que expressa os modelos culturais interiorizados. Por sua vez, esses modelos culturais refletem o caráter histórico e específico das relações sociais. Desta forma, os depoimentos têm que ser analisados num contexto de classe, geração, sexo, etc. Cada sujeito, pertencente a certos grupos sociais, informa sobre uma "subcultura", que the é específica e tem relações diferenciadas com a cultura dominante.

Por outro lado, Lane (1985, p.34) lembra que "os significados produzidos historicamente pelo grupo social adquirem, no âmbito do indivíduo, um 'sentido pessoal', ou seja, a palavra se relaciona com a realidade, com a própria vida e com os motivos de cada indivíduo". Assim sendo, a técnica de entrevista pareceu adequada à proposta de trabalho, 
uma vez que permitiu apreender o significado pessoal atribuído pela mãe ao cuidado da criança com pneumonia, significado este construído a partir dos elementos produzidos pelo grupo social, constitutivos do pensamento coletivo.

Foram realizadas entrevistas individuais e semi-estruturadas com os sujeitos. De acordo com Minayo (1992) e Richardson et al. (1985), a entrevista semi-estruturada ou "guiada" apresenta um certo grau de estruturação, permitindo ao entrevistador utilizar-se de uma relação de pontos de interesse a ser explorada ao longo de seu curso.

O roteiro (Anexo 1) empregado com o intuito de levar as mães a abordarem a temática de interesse para o estudo era composto de três partes, descritas a seguir. A primeira estava voltada para a classificação dos sujeitos em dois grupos: mães cujos filhos já haviam sido acometidos por pneumonia e mães sem esta experiência. A segunda parte era destinada a caracterizar os sujeitos do estudo e, nos casos em que se aplicava, a vivência do último episódio de pneumonia do filho. A última parte visava estimular a expressão materna relativa aos conhecimentos, atitudes $e$ condutas diante da criança com pneumonia. Cabe ressaltar que nem todos os tópicos da terceira etapa do roteiro foram explorados junto ao grupo de mães cujos filhos não tiveram pneumonia, por se reportarem à experiência de cuidado e tratamento de criança acometida por esta patologia.

As conversas entre pesquisadora e mães duraram em média 25 minutos e foram conduzidas em espaço reservado na própria unidade. Ocorreram no período de 9 de outubro a 11 de dezembro de 2001, em data e período que a mãe levava seu filho para atendimento no CSE, antes e/ou após a consulta médica, respeitando-se a preferência da mãe.

Inicialmente, a pesquisadora se apresentou às mães, esclarecendo seu nome, formação e ausência de vínculo empregatício com o serviço. Em seguida, expôs dados referentes ao estudo, entre eles o objetivo, a forma de participação dos sujeitos e a utilização das informações obtidas, assegurando o sigilo de identidade dos participantes. 
No que diz respeito aos princípios éticos da pesquisa houve preocupação em cumprir rigorosamente os passos previstos. As mães foram esclarecidas quanto à total liberdade de decisão sobre sua participação na pesquisa, destacando-se que a recusa ou a retirada de consentimento a qualquer momento não lhes traria qualquer prejuízo pessoalmente nem ao atendimento dos filhos no serviço. Em caso de consentimento, foi solicitada a assinatura do Termo de Consentimento Livre e Esclarecido (Anexo 2), tendo sido mantida uma cópia com a pesquisadora até o término do trabalho e outra entregue à participante.

No início das entrevistas, constatou-se uma certa resistência em expor as informações conhecidas sobre o tema por parte de algumas mães, sob a alegação de desconhecimento. Entretanto, à medida que se estabelecia um clima de confiança entre pesquisadora e entrevistada com o avanço da conversa, foram fornecidos dados sobre aspectos ditos desconhecidos num primeiro momento, notando-se uma clara mudança de atitude materna em relação à sua participação no estudo.

As informações obtidas foram registradas em formulário apropriado e gravadas, mediante permissão das mães. Isso viabilizou o registro integral dos depoimentos, garántindo maior fidedignidade em relação aos mesmos. Como Triviños (1992) bem lembrou, o gravador pode ter inibido as participantes num primeiro momento, mas acredita-se que as mesmas tenham superado esta dificuldade expressando-se de modo espontâneo rapidamente.

O conteúdo das gravações foi transcrito com a ajuda de dois estudantes de enfermagem e posteriormente revisado pela pesquisadora. Vale ressaltar que os colaboradores mencionados não tiveram acesso à identidade dos sujeitos e assumiram compromisso de não revelar as informações conhecidas.

No trabalho de transcrição, foi respeitada e conservada exatamente a maneira como cada sujeito se expressou. A esse respeito, Bardin (1977) destaca que a palavra ou o aspecto individual e atual da linguagem impresso 
pelo sujeito, constitui-se o objeto da análise de conteúdo, método utilizado para o tratamento do material coletado nesta pesquisa.

Com o propósito de entreter as crianças tornando possivel a conversa com as mães, a pesquisadora disponibilizou brinquedos a elas durante as entrevistas. Nos casos de concordância materna, foi também oferecido um lanche (suco de fruta, leite achocolatado, bolachas doce e salgada), uma vez que as mães e crianças permaneciam um período considerável no serviço e podiam apresentar fome. Tal estratégia se mostrou plenamente satisfatória quanto aos objetivos previstos e, ainda, revelou-se valiosa no sentido de criar um clima de confiança entre entrevistadora e entrevistadas.

Até a realização da décima oitava entrevista não houve direcionamento da pesquisadora no sentido de favorecer a participação de mulheres de um grupo ou de outro. Fazia-se o convite de participação às mães na sala de espera para atendimento infantil e eram incluídas aquelas que concordavam, não se fazendo antecipadamente distinção alguma quanto a possuirem, ou não, um filho que tivesse contraído pneumonia.

Como resultado, o conjunto de mães cujos filhos já haviam sido acometidos por pneumonia totalizava quatro integrantes apenas, contra catorze mães que não tinham vivido tal experiência. A partir de então, privilegiou-se a inclusão das primeiras, na tentativa de ampliar numericamente este contingente e, desse modo, alargar o corpo de material a ser analisado dentro do possível. Ao final, incorporou-se mais duas mulheres ao primeiro grupo.

Uma das entrevistas (E16) embora incompleta foi considerada neste estudo, porque sua interrupção se deu em fase já adiantada, havendo considerável conjunto de informações. A interrupção se deu em razão do atendimento da criança pelos profissionais do serviço e a mãe não retornou para completá-la, conforme combinado.

Ao final da conversa, todas se mostraram abertas a futuros contatos com a pesquisadora, caso houvesse necessidade de esclarecimentos 
relativos ao conteúdo da entrevista, exceto a mãe acima mencionada a qual não foi consultada a esse respeito, por falta de oportunidade.

Observou-se que algumas mães (E16, E19 e E20) manifestaram dúvidas e anseios por informaçōes sobre o tema explorado. Com base nisso, pode-se afirmar que há disponibilidade por parte da população para o desenvolvimento de atividades que discutam o tema das IRA na infância, destacando-se a importância de se utilizar de metodologia participativa para este fim. 


\subsection{Procedimento de análise do material obtido}

Os dados de caracterização dos sujeitos foram planilhados e, então, tabulados manualmente. Optou-se por apresentar apenas aqueles que ofereceram maior valor explicativo para o estudo, não mencionando os demais. Compôs-se um quadro intitulado "Perfil dos sujeitos" com as informações que se mostraram significativas para compreensão das falas dos sujeitos. O conjunto das informações referentes à caracterização dos sujeitos veio compor o contexto onde foram construídas as representações maternas.

Já os relatos das mães referentes às concepções e práticas relacionadas à criança com pneumonia foram tratados segundo o método de análise de conteúdo, comumente empregado nas pesquisas qualitativas, de acordo com Minayo (1992). Segundo Bardin (1977, p.42), a análise de conteúdo é "um conjunto de técnicas de análise das comunicações visando obter, por procedimentos, sistemáticos e objetivos de descrição do conteúdo das mensagens, indicadores (quantitativos ou não) que permitam a inferência de conhecimentos relativos às condições de produção/recepção (variáveis inferidas) destas mensagens".

Em outras palavras, a análise de conteúdo consiste de um tratamento descritivo, a partir de um conjunto de técnicas, que pretende explicitar e sistematizar as informações contidas nas mensagens, não se limitando ao conteúdo apenas. A finalidade última dessa abordagem é articular a descrição das características das comunicações com as suas condições de produção que determinaram estas características. Tal articulação é possível através da inferência ou dedução lógica de conhecimentos sobre o emissor e a situação em que se encontra, a partir de índices fornecidos pela fase descritiva da análise.

Desse modo, o pesquisador busca compreender o sentido das comunicações, atingindo outros 'significados' de natureza psicológica, 
sociológica, política, histórica, etc., que se encontram em segundo plano, aspirando uma interpretação fundamentada. A análise de conteúdo tem como função a descoberta do que está por trás dos conteúdos manifestos, indo além das aparências do que está sendo comunicado (Minayo 1994).

Minayo (1992) discute a persistência, ainda na atualidade, da polêmica entre a abordagem quantitativa e a qualitativa na análise do material de comunicação. Numa postura positivista, há uma obsessão pela objetividade e rigor, enfatizando-se o quantitativo e o conteúdo manifesto das comunicações. Já os adeptos das técnicas qualitativas questionam a minúcia da análise de freqüência como critério de objetividade e cientificidade e buscam ultrapassar o alcance meramente descritivo do conteúdo manifesto na linguagem para atingir uma interpretação mais aprofundada mediante a inferência.

Franco (1986) chama atenção para essa interpretação dicotomizada e equivocada, que pressupõe oposições estanques entre análises qualitativas e quantitativas. No processo de coleta de dados, o pesquisador pode interessar-se por conhecer a frequência com que um fenômeno ocorre em determinada realidade, expressando seus resultados em números. Ao contextualizá-los e interpretá-los à luz da dinâmica social mais ampla extrapolando uma simples descrição factual, sua análise será eminentemente qualitativa.

Procede então, aceitar uma articulação entre esses dois aspectos, em particular quando se trata de pesquisa descritiva, onde os números também podem exercer uma função crítica. Tal situação se observa à medida que pode fortalecer argumentos, demonstrando tendências predominantes e destacando divergências e proporções existentes entre as desigualdades sociais.

No procedimento de análise do material realizado nessa pesquisa, utilizou-se do recurso de contagem de freqüência em diversos subtemas (como por exemplo, doenças conhecidas, manifestações clínicas e causas 
da pneumonia), de modo a evidenciar a predominância de certos elementos nas concepções das mães entrevistadas.

Entre as diversas técnicas de análise de conteúdo possiveis, optou-se pela análise temática, por se aplicar a estudos sobre motivações de opiniōes, de atitudes, de valores, de crenças, de tendências, etc. (Bardin 1977). Este tipo de análise é dos mais utilizados entre aqueles que aplicam análise de conteúdo.

A análise de conteúdo implica a decomposição do conjunto de uma mensagem em seus elementos constitutivos chamados 'unidades de registro'. Tais unidades se referem ao segmento de conteúdo considerado como unidade base de análise, visando a categorização e a contagem de freqüência.

$\mathrm{Na}$ análise temática, conforme Bardin (1977) esclarece, o tema é utilizado como unidade de registro, correspondendo a uma regra de recorte do texto baseada no sentido e não na forma. Assim, a análise temática consiste em descobrir os "núcleos de sentido" contidos nas comunicações, cuja presença ou freqüência podem ter algum significado (Minayo 1992).

Para Urung apud Minayo (1992), o tema é "uma unidade de significação complexa de comprimento variável, a sua validade não é de ordem lingüística, mas antes de ordem psicológica. Pode constituir um tema tanto uma afirmação como uma alusão" (p.209).

Cronológica e operacionalmente, a análise temática compreende três etapas: a pré-análise, que consiste na organização do material; a exploração do material, que abrange os procedimentos de codificação, classificação e categorização; e o tratamento dos resultados obtidos e a interpretação, quando são estabelecidas relações entre os dados, por meio de reflexão e intuição, buscando-se ir além do conteúdo manifesto dos documentos, tratando de desvendar o conteúdo latente que eles possuem. Desse modo, conforme declara Triviños (1992), abre-se perspectivas para descobrir ideologias, tendências, etc. das características dos fenômenos sociais estudados, sendo a análise dinâmica, estrutural e histórica. 


\section{COMPREENDENDO OS DISCURSOS MATERNOS}

Neste capitulo, inicialmente, é oferecida uma apresentação da região do Butantã e, particularmente, da área de abrangência do Centro de Saúde Escola "Prof. Samuel Barnsley Pessoa", a fim de caracterizar o cenário do estudo. São então exibidos os dados referentes à caracterização das mães, os sujeitos participantes desta pesquisa. Tal conjunto de informações permite a apreensão do contexto em que se deu a construção dos discursos acerca das concepções e das práticas de cuidado domiciliar da criança com pneumonia.

A seguir, são apresentadas as categorias de análise formuladas a partir do trabalho realizado junto ao corpo de material, segundo o método de análise de conteúdo, a análise temática em particular. A discussão dos resultados é desenvolvida à medida que vão sendo oferecidos os elementos da análise. 


\subsection{Cenário do estudo}

\subsubsection{A região do Butantã}

Conforme o relato de Maria José Silva Querido (Querido 1999), foi por volta de 1560 que surgiram as primeiras notícias que se têm do Butantã. Era rota de passagem e bandeirantes e jesuítas que se dirigiam ao interior do pais.

O desenvolvimento do Butantã ocorreu a partir da instalação do Instituto Butantã, em 1899. O instituto foi fundado em resposta a um surto de peste bubônica que acometia os habitantes do município de São Paulo na ocasião. Algumas décadas depois, foi destinada parte do terreno pertencente ao Instituto Butantã para a instalação da Cidade Universitária da Universidade de São Paulo.

Em 1915, a Companhia City Melhoramentos, responsável pela urbanização das margens do Rio Pinheiros, comprou uma importante área no Butantã e iniciou o loteamento da região. Com os serviços de infraestrutura realizados no local a fim de atrair o interesse de setores diferenciados da população, teve início o processo de urbanização.

A partir dos anos 20, começaram a surgir os primeiros bairros da região, crescimento que se estendeu pelas décadas seguintes dando origem a muitos outros. Foi no final de 40 que o Morumbi, até então ocupado por chácaras e pequenas fazendas, tornou-se área residencial, graças ao loteamento implementado pela Companhia Imobiliária Morumby.

Assim, segundo técnicos do Centro de Educação Ambiental da região (Chiesa 1999), a ocupação do território do Butantã que se iniciou por bairros planejados passou a partir dos anos 60 a apresentar uma ocupação de forma mais indiscriminada, surgindo favelas no local. 
Conforme documento da Prefeitura (Prefeitura 1984), observou-se significativo crescimento demográfico na área nos anos 60/70 e 70/80 em relação às demais regiões do município de São Paulo. Em visitas feitas à área, detectou-se grande expansão com o surgimento de inúmeras construções novas, envolvendo tanto conjuntos residenciais e prédios de apartamentos como também aglutinação da população em favelas, núcleos e cortiços. Tal expansão se referiu principalmente aos setores Oeste e Sudeste do Butantã, constatando-se crescimento considerável do contingente de população de baixa renda no primeiro e maior expansão da população de renda média alta no último.

Conforme Querido (1999), atualmente a área do Butantã é predominantemente residencial, totalizando 280 bairros. A maior parte da população é de baixa renda, concentrada em bairros da periferia, como Jardim João XXIII, Jardim Arpoador, Jardim D'Abril e Vila Dalva. As populações de renda média e alta residem nas melhores áreas, quais sejam: Morumbi, City Butantã e Cidade Jardim.

Apresenta bacia hidrográfica bastante exuberante, formada pelo Rio Pinheiros e 46 córregos, sendo apenas uma parte deles canalizada. Devido a isto, ocorrem enchentes com a invasão das áreas ribeirinhas, causando danos à população residente.

Segundo o documento Base de Dados Administração Regional do Butantã - 2001 (Prefeitura 2001), o território da Administração Regional do Butantã (AR-Bt) tem $56,1 \mathrm{~km}^{2}$, correspondendo a $3,75 \%$ da área total do Município de São Paulo. A área é formada pelos seguintes distritos ou microregiões: Butantã, Morumbi, Raposo Tavares, Rio Pequeno e Vila Sônia.

A AR-Bt se situa a oeste do municipio de São Paulo, limitando-se ao Norte com AR-Lapa (pelas avenidas Corifeu de Azevedo Marques e Nossa Senhora da Paz); a Oeste com os municípios de Osasco e Taboão da Serra; ao Sul com AR-Campo Limpo (pela Av. Marechal Juarez Távora, Rua Marechal Hastimphilo de Moura, Av. Giovani Gronchi, Rua Flávio Américo 
Murano e Av. Morumbi); e a Leste com AR-Pinheiros e AR-Santo Amaro (Rio Pinheiros).

De acordo com o Censo de 2000 (Fundação IBGE 2001), a população da AR-Bt é de 377.576 habitantes. Foi observado um decréscimo populacional na região entre o Censo de 1991 e a Contagem populacional de 1996. Tal desaceleração no ritmo de crescimento demográfico acompanha o mesmo padrão verificado de um modo geral em todo município de São Paulo e deve-se à redução das taxas migratórias, como também à diminuição nos níveis de fecundidade.

Conforme Base de Dados da AR-BT-2001 (Prefeitura 2001), em 1996, o número de domicílios era de 152.443 , com uma média de 3,4 moradores em cada. Havia 45.978 habitantes residindo em favelas, o que correspondia a $13 \%$ da população total dos cinco distritos.

Sabe-se que a população moradora em favelas vem crescendo acentuadamente nas últimas décadas, em função do crescimento da cidade e, principalmente, devido à crescente dificuldade de acesso da população à moradia. A renda das famílias faveladas tem melhorado, em decorrência do ingresso na favela de novas familias com maiores rendimentos, que não encontram outra solução para seu problema de moradia no mercado.

Conforme o exposto, cabe destacar que nos dias de hoje, constitui-se uma região da periferia do município, onde predomina fratura das relações interpessoais não guardando, desse modo, qualquer relação com a origem rural e provinciana da área. 


\subsubsection{O Centro de Saúde Escola "Prof. Samuel Barnsley Pessôa"}

O Centro de Saúde Escola "Prof. Samuel Barnsley Pessôa" (CSE) foi fundado em 1977, a partir de um convênio entre o Departamento de Medicina Preventiva da Faculdade de Medicina da USP e a Secretaria de Estado da Saúde de São Paulo. Constitui-se uma das catorze unidades básicas de saúde que compõem o Distrito Sanitário do Butantã, situado à avenida Vital Brasil n¹490.

Os limites da área de abrangência estabelecidos para a atuação do CSE não são contíguos em razão de existir outra unidade básica na região por ocasião de sua fundação. $O$ acesso por ônibus foi o critério utilizado para definição de sua área de abrangência, englobando parte dos distritos do Rio Pequeno e Butantã pertencentes à AR-Bt.

Conforme informações verbalmente fornecidas por profissional habilitado do CSE, no Setor de Saúde da Criança CSE foram feitos 11.105 atendimentos pediátricos no ano de 2001. Sendo o CSE uma unidade prestadora de serviços da USP, voltada para o ensino e a pesquisa nas áreas da saúde, os atendimentos são efetuados pelo alunado supervisionado por profissionais de saúde do serviço.

Em investigação realizada no CSE, em 1995, foram analisados atendimentos pediátricos caracterizados por consultas de rotina previamente agendadas e eventuais não aprazadas, que totalizaram 399 crianças de 0 a 12 anos de idade (Gomes et al. 1997). Das crianças menores de cinco anos incluídas no estudo (306 crianças), $46 \%$ apresentaram quadros de infecções respiratórias agudas, observando-se uma concentração um pouco maior no grupo etário de menores de 2 anos. Na faixa etária em questão, os agravos nas vias aéreas superiores corresponderam a mais de $85 \%$ dos diagnósticos predominando a rinofaringite aguda, enquanto que as infecções de trato respiratório inferior representaram apenas $13 \%$ havendo entre estas últimas 10 casos de pneumonia. 
A fim de caracterizar os distritos Butantã e Rio Pequeno, que compõem parcialmente a área de abrangência do CSE, disponibilizaram-se as informações que se seguem.

Apesar da área territorial do Butantã $\left(12,9 \mathrm{~km}^{2}\right)$ ser pouco maior que a do Rio Pequeno $\left(9,8 \mathrm{~km}^{2}\right)$, o contingente populacional deste último representa mais do dobro do anterior. Segundo o Censo de 2000 (Fundação IBGE 2001), a população residente no distrito Butantã é de 52.649 habitantes, sendo $2.686(5,1 \%)$ crianças menores de cinco anos. Já o Rio Pequeno reúne 111.756 habitantes, dos quais 9.570 (8,5\%) estão na faixa etária inferior a cinco anos. Há uma média de 3,18 moradores por domicilio no primeiro e de 3,58 no segundo.

Quanto à escolaridade e rendimento dos responsáveis pelos domicílios, no Butantã tem-se que $63 \%$ dos indivíduos tinham alcançado completar pelo menos o ensino médio e $69 \%$ percebiam uma renda mensal igual ou superior a 5 salários mínimos. No Rio Pequeno, $61 \%$ tinham apenas cursado anos do ensino fundamental, incluídos os sem instrução, e $45 \%$ tinham rendimento menor que 5 salários mínimos ao mês (Fundação IBGE 2001).

De acordo com dados da regional (São Paulo 2001), o Rio Pequeno é o distrito que apresenta maior número de favelas (16). Embora a situação atual deva ter sofrido algumas alterações, com base na contagem populacional do IBGE, $19,67 \%$ da população (19.553 habitantes) residiam em favelas em 1996. No Butantã, este número revelou-se muitíssimo menor: 140 habitantes favelados, que representavam $0,26 \%$ da população do distrito no mesmo ano.

No "ranking" de classificação geral dos 96 distritos do município de São Paulo quanto à exclusão social, construído por Sposati (1996), as referidas áreas ocupam posições muito diferentes. Em ordem crescente, do distrito em piores condições para o melhor, o Rio Pequeno ocupa a $38^{a}$ posição enquanto que o Butantã está colocado em $88^{\circ}$ lugar. Melhor dizendo, no Rio Pequeno identificou-se a presença de diversas condiçōes de 
exclusão, enquanto que o Butantã se caracterizou por apresentar indicadores de inclusão social.

A mesma autora, em outro trabalho (Sposati e Koga 1996), calculou o risco de sobrevivência para crianças nos diversos distritos paulistanos. $O$ distrito do Rio Pequeno apresentou um alto risco de sobrevivência para as crianças, ficando na faixa entre 30 e $40 \%$, enquanto que o Butantã ofereceu um risco menor, de 10 a $20 \%$.

Finalizando, Chiesa (1999), à semelhança dos estudos de Sposati, levou a cabo uma investigação na área de abrangência do CSE, que trouxe avanços no sentido de refinar a caracterização das condições materiais de vida da população adscrita. O estudo permitiu identificar diferentes necessidades da população residente em áreas homogêneas do ponto de vista sócio-econômico e ambiental, isto é, com diferentes "chances de vida" e de adoecer por IRA, e suas mediações no que toca à vivência dos problemas respiratórios.

A partir do "ranking" dos setores censitários pertencentes à área do CSE, foram identificados 4 grupos homogêneos em termos do potencial de exposição às condições de risco para IRA: o Grupo I, que reúne as melhores condições de vida; o Grupo II, que reflete uma situação intermediária boa; o Grupo III, que apresenta uma situação regular e ruim; e - Grupo IV, que agrega as piores condições de base para a população residente.

Nota-se que a parcela da área de abrangência do CSE pertencente ao distrito do Butantã corresponde predominantemente a setores classificados como Grupos I e II, onde se encontram as melhores e intermediárias condições de vida, enquanto que a do Rio Pequeno é caracterizada por áreas em condições de vida regulares e ruins (Grupo III), entremeadas por bolsões de pobreza (favelas) que apresentam as piores condições de base (Grupo IV) e raros espaços melhores (Grupos I e II).

Grosso modo, as informaçōes apresentadas explicitam uma considerável disparidade entre os distritos no que diz respeito às condições 
de vida da população nas respectivas micro-regiões. Pode-se notar que a população residente no Butantã desfruta de uma situação bastante mais favorável que a do Rio Pequeno, apesar de ambos terem presentes condiçōes que oferecem algum grau de risco à vida. 


\subsection{Caracterização dos sujeitos do estudo}

As informações que tornaram possivel caracterizar as mães estão apresentadas no Quadro 1, intitulado "Perfil dos sujeitos", exibido nas páginas que se seguem. Os dados foram analisados e foram feitas considerações a fim de tecer o contexto de vida dos sujeitos, onde se constróem seus conhecimentos e práticas em relação à criança com pneumonia.

O quadro apresentado permite um exame detalhado relativo à idade das mães entrevistadas. As mães variaram bastante quanto à idade, havendo uma maior concentração (12) na faixa etária de 20 a 29 anos (60\%). Nos demais agrupamentos etários, a distribuição foi homogênea. Considerando que fizeram parte do estudo mães de crianças menores de 5 anos de idade, é compreensivel o fato da maioria ser representada por mulheres jovens.

Em relação ao estado civil, não importando se a união do casal estava legalizada ou não, catorze mulheres $(70 \%)$ relataram viver com o companheiro, também pai dos filhos. A esta situação denominou-se "casada". Os estados de "solteira", "separada" e "viúva", estabelecidos tendo como referência a definição de "casada", foram representados por duas mães $(10 \%)$ cada. A alta freqüência de "casadas" em comparação às outras categorias se explica, por um lado, por considerar-se a união conjugal sem levar em conta sua formalidade, e por outro, pelos sujeitos se tratarem de mães, ou melhor, mulheres que tinham filho(s). 
Quadro 1. Perfil dos sujeitos, 2002.

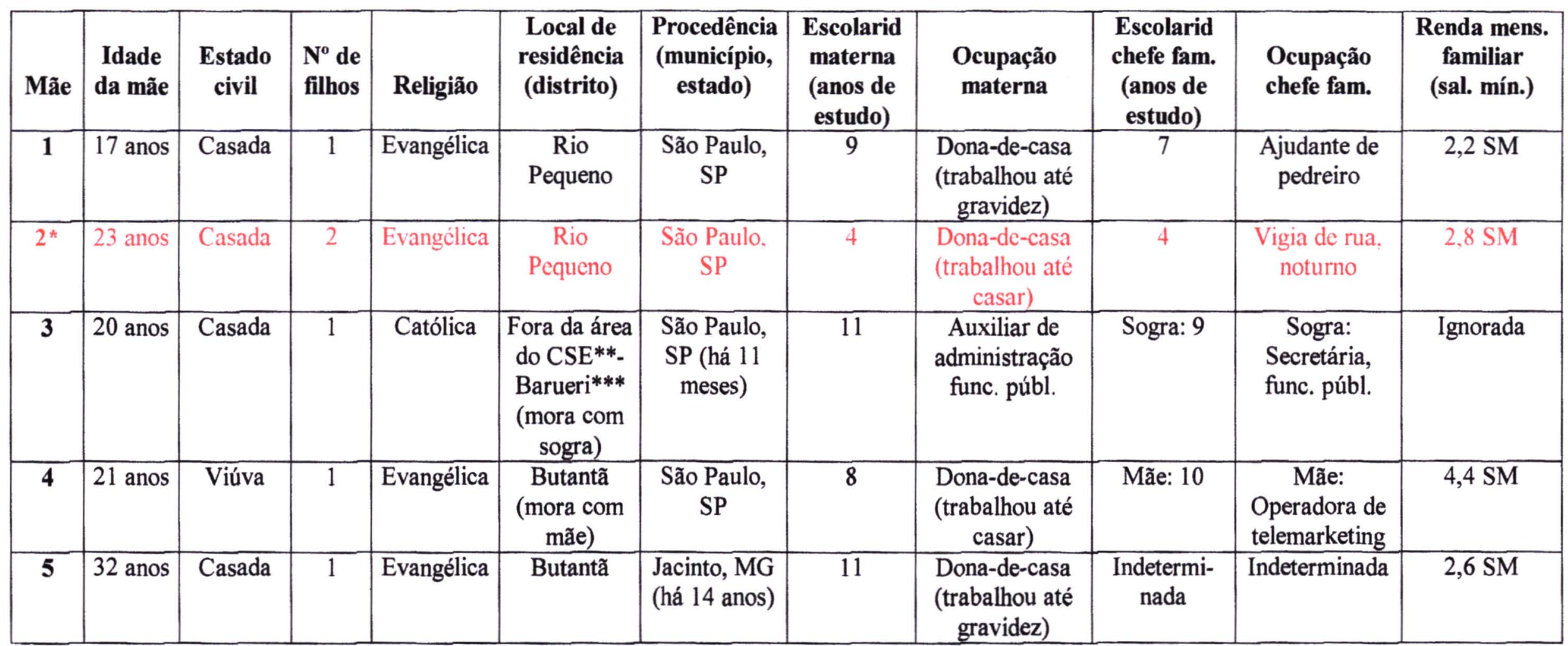

* Mães que tiveram a experiência de ter um filho acometido por pneumonia com idade entre 2 meses e 4 anos

** No registro do CSE, consta um endereço residencial pertencente à área de abrangência, diferente do informado pela mãe

*** Barueri, município da Região Metropolitana de São Paulo 


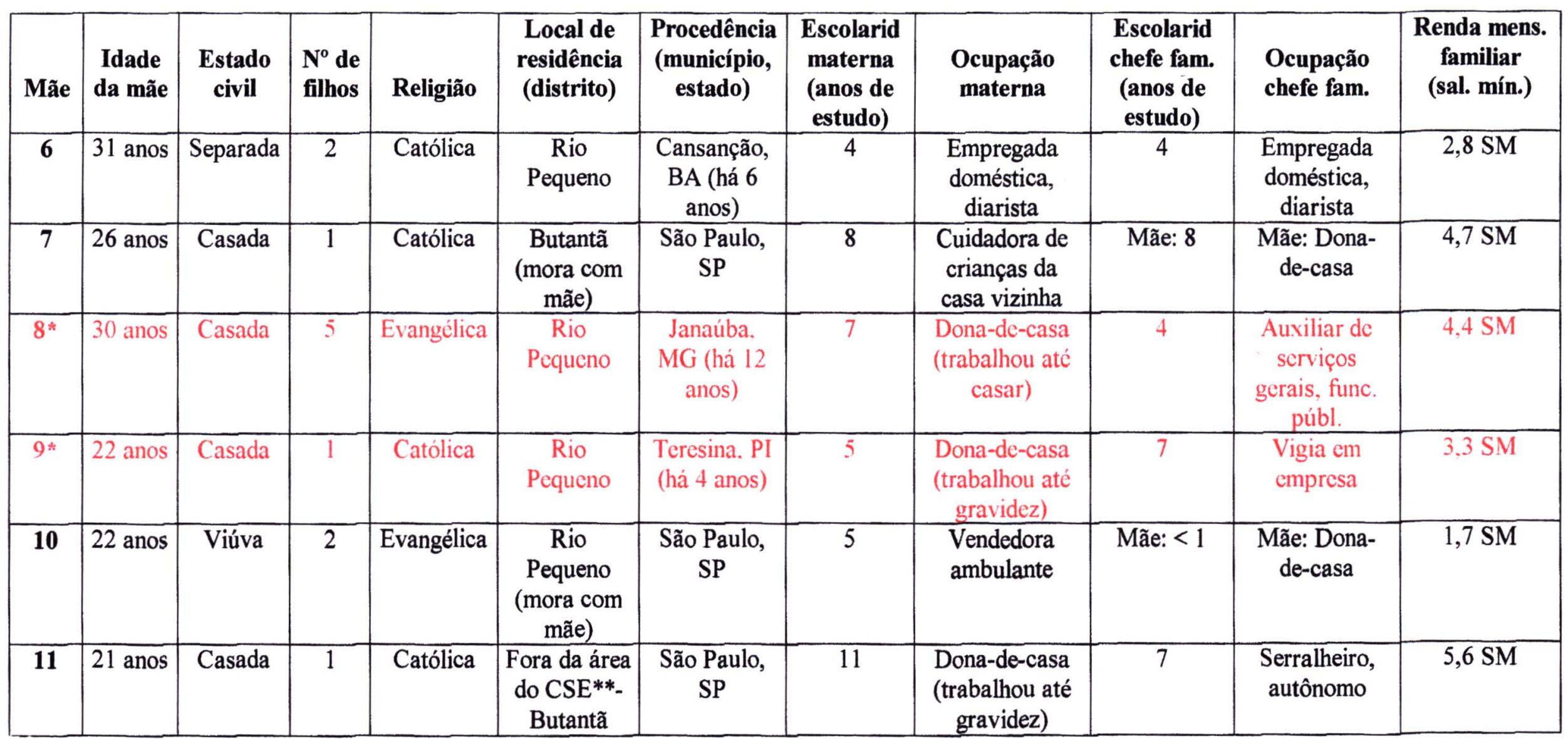

* Mães que tiveram a experiência de ter um filho acometido por pneumonia com idade entre 2 meses e 4 anos

** No registro do CSE, consta um endereço residencial pertencente a área de abrangência, diferente do informado pela mãe 


\begin{tabular}{|c|c|c|c|c|c|c|c|c|c|c|c|}
\hline Mãe & $\begin{array}{l}\text { Idade } \\
\text { da mãe }\end{array}$ & $\begin{array}{c}\text { Estado } \\
\text { civil }\end{array}$ & $\begin{array}{l}N^{\circ} \text { de } \\
\text { filhos }\end{array}$ & Religião & $\begin{array}{l}\text { Local de } \\
\text { residência } \\
\text { (distrito) }\end{array}$ & $\begin{array}{c}\text { Procedência } \\
\text { (município, } \\
\text { estado) }\end{array}$ & $\begin{array}{c}\text { Escolarid } \\
\text { materna } \\
\text { (anos de } \\
\text { estudo) } \\
\end{array}$ & $\begin{array}{l}\text { Ocupação } \\
\text { materna }\end{array}$ & $\begin{array}{l}\text { Escolarid } \\
\text { chefe fam. } \\
\text { (anos de } \\
\text { estudo) } \\
\end{array}$ & $\begin{array}{l}\text { Ocupação } \\
\text { chefe fam. }\end{array}$ & $\begin{array}{l}\text { Renda mens. } \\
\text { familiar } \\
\text { (sal. mín.) }\end{array}$ \\
\hline 12 & 18 anos & Casada & 1 & Católica & Butantã & $\begin{array}{l}\text { São Paulo, } \\
\text { SP }\end{array}$ & 10 & Dona-de-casa & 10 & $\begin{array}{c}\text { Funileiro civil } \\
\text { autônomo }\end{array}$ & $2,8 \mathrm{SM}$ \\
\hline 13 & 17 anos & Casada & 1 & Católica & $\begin{array}{c}\text { Rio } \\
\text { Pequeno } \\
\text { (mora com } \\
\text { irmãos) } \\
\end{array}$ & $\begin{array}{l}\text { Bom Jesus } \\
\text { da Lapa, BA } \\
\text { (há } 12 \text { anos) }\end{array}$ & 8 & $\begin{array}{c}\text { Desempregada, } \\
\text { (faxineira e } \\
\text { balcão de } \\
\text { padaria) }\end{array}$ & 6 & $\begin{array}{l}\text { Lavador de } \\
\text { carro em Lava } \\
\text { Rápido }\end{array}$ & Ignorada \\
\hline $14^{*}$ & 22 anos & Scparada & 2 & Católica & $\begin{array}{c}\text { Rio } \\
\text { Pequeno }\end{array}$ & $\begin{array}{l}\text { São Paulo, } \\
\text { SP }\end{array}$ & 4 & $\begin{array}{l}\text { Desempregada, } \\
\text { (faxineira em } \\
\text { firma de } \\
\text { limpeza) }\end{array}$ & 4 & $\begin{array}{l}\text { Desempregada } \\
\text { (faxineira em } \\
\text { firma de } \\
\text { limpeza) }\end{array}$ & I SM \\
\hline 15 & 20 anos & Solteira & 1 & Católica & $\begin{array}{l}\text { Butantã } \\
\text { (mora com } \\
\text { mãe) }\end{array}$ & $\begin{array}{l}\text { Peruíbe, SP } \\
\text { (há } 9 \text { anos) }\end{array}$ & 9 & $\begin{array}{c}\text { Dona-de-casa } \\
\text { (trabalhou até } \\
\text { gravidez) }\end{array}$ & Padrasto: 11 & $\begin{array}{c}\text { Padrasto: } \\
\text { proprietário } \\
\text { loja de peças } \\
\text { de caminhão }\end{array}$ & $13,1 \mathrm{SM}$ \\
\hline 16 & 29 anos & Solteira & 1 & Católica & $\begin{array}{l}\text { Butantã } \\
\text { (mora no } \\
\text { emprego) }\end{array}$ & $\begin{array}{l}\text { São Paulo, } \\
\text { SP }\end{array}$ & 3 & $\begin{array}{l}\text { Empregada } \\
\text { doméstica, } \\
\text { mensalista }\end{array}$ & 3 & $\begin{array}{l}\text { Empregada } \\
\text { doméstica, } \\
\text { mensalista }\end{array}$ & $2,2 \mathrm{SM}$ \\
\hline 17 & 19 anos & Casada & 1 & Nenhuma & $\begin{array}{c}\text { Butantã } \\
\text { (mora com } \\
\text { pai) }\end{array}$ & $\begin{array}{l}\text { São Paulo, } \\
\text { SP }\end{array}$ & 5 & Dona-de-casa & $\begin{array}{l}\text { Pai: nenhum } \\
\text { (analfabeto) }\end{array}$ & $\begin{array}{c}\text { Pai: } \\
\text { desempregado } \\
\text { (faxineiro) }\end{array}$ & $2,2 \mathrm{SM}$ \\
\hline
\end{tabular}

${ }^{*}$ Mães que tiveram a experiência de ter um filho acometido por pneumonia com idade entre 2 meses e 4 anos

** No registro do CSE, consta um endereço residencial pertencente à área de abrangência, diferente do informado pela mãe 


\begin{tabular}{|c|c|c|c|c|c|c|c|c|c|c|c|}
\hline Mãe & $\begin{array}{l}\text { Idade } \\
\text { da mãe }\end{array}$ & $\begin{array}{c}\text { Estado } \\
\text { civil }\end{array}$ & $\begin{array}{l}N^{\circ} \text { de } \\
\text { filhos }\end{array}$ & Religião & $\begin{array}{c}\text { Local de } \\
\text { residência } \\
\text { (distrito) }\end{array}$ & $\begin{array}{c}\text { Procedência } \\
\text { (município, } \\
\text { estado) }\end{array}$ & $\begin{array}{l}\text { Escolarid } \\
\text { materna } \\
\text { (anos de } \\
\text { estudo) } \\
\end{array}$ & $\begin{array}{l}\text { Ocupação } \\
\text { materna }\end{array}$ & $\begin{array}{l}\text { Escolarid } \\
\text { chefe fam. } \\
\text { (anos de } \\
\text { estudo) }\end{array}$ & $\begin{array}{l}\text { Ocupação } \\
\text { chefe fam. }\end{array}$ & $\begin{array}{c}\text { Renda mens. } \\
\text { familiar } \\
\text { (sal. mín.) }\end{array}$ \\
\hline 18 & 42 anos & Casada & 1 & Umbanda & $\begin{array}{c}\text { Rio } \\
\text { Pequeno }\end{array}$ & $\begin{array}{c}\text { São Paulo, } \\
\text { SP }\end{array}$ & 8 anos & $\begin{array}{l}\text { Dona-de-casa, } \\
\text { bico: faxineira } \\
\text { (cuida da filha) }\end{array}$ & $\begin{array}{c}\text { Nenhum } \\
\text { (analfabeto) }\end{array}$ & $\begin{array}{l}\text { Ajudante de } \\
\text { mecânico }\end{array}$ & $0,4 \mathrm{SM}$ \\
\hline $19^{*}$ & 29 anos & Casada & 2 & Evangélica & $\begin{array}{c}\text { Rio } \\
\text { Pequeno }\end{array}$ & $\begin{array}{l}\text { Feira Nova, } \\
\text { PE (há } 12 \\
\text { anos) }\end{array}$ & 6 anos & $\begin{array}{l}\text { Ajudante de } \\
\text { cozinha em } \\
\text { restaurante }\end{array}$ & 4 anos & $\begin{array}{l}\text { Dono de bar } \\
\text { em casa }\end{array}$ & $3,8 \mathrm{SM}$ \\
\hline $20^{*}$ & 27 anos & Casada & 2 & Evangélica & $\begin{array}{c}\text { Rio } \\
\text { Pequeno** }\end{array}$ & $\begin{array}{l}\text { Rondônia } \\
\text { (há } 5 \text { anos) }\end{array}$ & 8 anos & $\begin{array}{c}\text { Faxineira, } \\
\text { diarista } \\
(2 \mathrm{x} / \mathrm{sem})\end{array}$ & Ignorada & $\begin{array}{c}\text { Empreiteiro, } \\
\text { construção } \\
\text { civil }\end{array}$ & $6,9 \mathrm{SM}$ \\
\hline
\end{tabular}

* Mães que tiveram a experiência de ter um filho acometido por pneumonia com idade entre 2 meses e 4 anos

** No registro do CSE, consta um endereço residencial pertencente à área de abrangência, diferente do informado pela mãe 
A publicação "Tabulação avançada do Censo Demográfico 2000" (Fundação IBGE 2002) revelou que praticamente $50 \%$ da população com 10 anos ou mais vivem em união conjugal, incluindo os casamentos legais e as uniōes consensuais. As mulheres se casam mais cedo e a partir dos 35 anos de idade começam a apresentar declínio da taxa de nupcialidade.

As mulheres solteiras, viúvas e separadas se encontravam em situações de vida muito diversas. Havia aquelas, uma solteira (E15) e duas viúvas recentes (E4 e E10), que residiam com parentes que as amparavam em todos os sentidos, inclusive o financeiro. As mulheres separadas (E6 e E14) habitavam com seus filhos em moradia independente e proviam suas necessidades materiais.

Outra solteira (E16) era chefe de família e morava no domicilio de seus empregadores, juntamente com seu filho. Tal situação tem suas particularidades, pois, de um lado, esta mulher respondia pelo sustento da familia (ela e filho), mas, por outro, pode-se supor que recebesse algum apoio da família que a empregava, a ponto de acolherem seu filho para morar na casa junto da mãe.

É interessante mencionar que outras duas mães, vivendo com o marido e filho(s), compartilhavam a moradia com parentes, tais como mãe, pai, padrasto, sogra, irmãos e cunhados, configurando molde de família do tipo extensa. As demais (12) co-habitavam com marido e filhos.

Cabe comentar ainda que a proporção de famílias (35\%) sob responsabilidade feminina, exercida pela entrevistada ou outra moradora do domicílio, foi bastante elevada. A tendência de aumento das famílias chefiadas por mulheres observada nos últimos censos se apoia em algumas justificativas. No caso daquelas em idade mais avançada, há a esperança de vida ao nascer em média oito anos maior para as mulheres do que para os homens. Além disso, nas duas últimas décadas, processou-se uma maior autonomia econômica e cultural feminina (Fundação IBGE 2002).

Quanto ao número de filhos, quase a totalidade das mães (19) referiu possuir um ou dois filhos, excetuando-se uma única (E8) com prole mais 
avantajada de 5 filhos. Não se pode deixar de considerar que a idade média das entrevistadas (24,4 anos) era bastante jovem por ocasião da pesquisa, o que significa que ainda tinham vida fértil prolongada futura e que o número de filhos poderia aumentar.

Entretanto, o dado encontrado é congruente com as mudanças observadas recentemente, confirmadas pela evolução da taxa de fecundidade total que vem decrescendo de modo acelerado e intenso, acompanhando uma tendência mundial de redução. No Brasil, a queda da fecundidade teve início na década de 60 , intensificou-se nas duas seguintes e continuou na última de forma moderada (Fundação IBGE 2000).

De acordo com a Pesquisa de Condições de Vida - 1998, realizada pela Fundação SEADE (internet), o tamanho médio das famílias residentes na Região Metropolitana de São Paulo passou de 3,65 para 3,45 componentes, entre 1994 e 1998, em parte em decorrência da sensível diminuição do número de famílias com mais de dois filhos. $O$ documento da AR-Bt (São Paulo 2001) aponta que, nos distritos Butantã e Rio Pequeno, onde residem os sujeitos deste estudo em particular, o número médio de moradores por domicílio era de 3,16 e 3,59 respectivamente, em 1996.

No aspecto religioso, dez informantes se declararam católicas, oito evangélicas, uma umbandista e uma sem credo. Com base no levantamento da AR-Bt (São Paulo 2001) e no documento sobre o Butantã organizado por Querido (1999), há igrejas católicas, templos evangélicos e tenda de umbanda localizados nos distritos onde residiam as mães.

O Censo de 2000 (Fundação IBGE 2002) revelou uma mudança significativa em relação à religiosidade da população. Embora o Brasil continue sendo um país majoritariamente católico, a proporção de adeptos da Igreja Católica sofreu considerável redução (queda de 12\%). Ao mesmo tempo, registrou-se um crescimento acentuado de evangélicos, passando a quase o dobro do número declarado em 1991 ao atingir $15,4 \%$, sendo a maioria pertencente a igrejas de origem pentecostal. Encontrou-se ainda uma proporção maior de evangélicos, devotos de outras religiões e 
declarados sem religião nos centros urbanos, representando os católicos $71,5 \%$ nestas áreas contra $83,5 \%$ encontrados nas zonas rurais.

Quanto ao local de residência, a maioria das mães morava dentro da área de abrangência do CSE, exceto duas (E3 e E11). A primeira residia no município de Barueri, localizado a Oeste na Região Metropolitana de São Paulo, e a segunda em logradouro situado no próprio distrito do Butantã, bastante próximo dos limites da área de abrangência da unidade.

Durante a entrevista, elas forneceram à pesquisadora, endereços diferentes daqueles que constavam em seus cadastros no serviço. Os últimos eram pertencentes à área de cobertura do serviço, o que lhes assegurava atendimento no mesmo.

Segundo informações colhidas de funcionário do SAME do CSE, os dados pessoais dos indivíduos matriculados no serviço são atualizados a cada três anos e o endereço informado deve ser comprovado com correspondência comercial em nome do interessado ou com declaração de pessoas reconhecidas como habilitadas para tanto, como proprietário do imóvel alugado, líder comunitário etc. Recentemente, tem havido por parte do serviço uma preocupação com a confirmação do endereço dos indivíduos que se encontram nesta última situação através de visita domiciliária, quando possivel.

Muitas podem ser as justificativas para o endereço informado não corresponder ao endereço registrado no CSE. Entre as mais óbvias, poderse-ia supor que a família mudou de moradia e seus dados ainda não foram atualizados no serviço. Entretanto, cabe também pensar que tal fato seja um indicador de que o atendimento prestado no CSE é considerado satisfatório pelas mães ou, pelo menos, melhor do que outros aos quais tenham acesso e, por isso, elas busquem formas de se beneficiar dele.

Onze mães residiam no distrito do Rio Pequeno e oito no Butantã. Cabe lembrar que o Rio Pequeno reúne maior contingente maior populacional em piores condições de vida se comparado ao Butantã. 
Quanto à procedência, treze mães eram naturais do estado de São Paulo, sendo doze da capital e uma do litoral paulista. A procedência das demais mulheres era muito variada, reunindo localidades do interior de estados das regiões Norte (Piauí e Rondônia), Nordeste (Bahia e Pernambuco) e Sudeste (Minas Gerais) do país. Tal fato é compreensivel uma vez que a Região Sudeste do Brasil, notadamente o Estado de São Paulo, caracteriza-se como uma área que exerceu e ainda exerce forte atração de migrantes de todas as partes do país (Fundação IBGE 2002). Cabe esclarecer que todas aquelas oriundas de fora do município de São Paulo moravam em média há nove anos nele.

Buscando caracterizar as condições sócio-econômicas das famílias das entrevistadas, foram investigadas informações relativas à escolaridade $e$ ocupação materna e do chefe da família e ao rendimento mensal do grupo familiar. Entretanto, existe um certo grau de dificuldade na obtenção deste tipo de dado tanto por desconhecimento quanto por falseamento da informação por parte do declarante. Assumindo essas limitações, são exibidos e analisados os dados levantados.

Quanto ao nivel de escolaridade, dezesseis participantes da pesquisa (85\%) tinham cursado no máximo ensino fundamental, tendo algumas (8) completado e as outras (9) não, e três haviam concluído o ensino secundário.

Em relação à ocupação materna, nove $(45 \%)$ relataram trabalhar regularmente, muito embora duas (E13 e E14) estivessem desempregadas há algum tempo com intenções de se recolocar no mercado de trabalho brevemente. Onze não realizavam atividade de trabalho remunerado restringindo sua atuação ao âmbito da própria casa, exceto por uma (E18) que esporadicamente realizava faxina em caráter de "bico". Vale comentar que a grande maioria dessas últimas (9) já havia desenvolvido alguma ocupação fora-de-casa no passado, tendo-a interrompido em razão de casamento, gravidez ou cuidado dos filhos. 
Das sete mães que se encontravam economicamente ativas no momento da entrevista, foi possivel constatar que praticamente todas (6) desempenhavam funções predominantemente femininas, tais como serviço doméstico, cuidado de crianças, trabalho em cozinha (restaurante) e venda ambulante ("sacoleira"). Geralmente esse tipo de atividade de trabalho oferece maior flexibilidade de horário, permitindo às mulheres conciliá-la com outras atribuições entre elas o cuidado da própria casa e dos filhos. Por outro lado, tais atividades gozam de menor prestígio social por se enquadrarem na categoria de ocupações manuais não especializadas, segundo Gouveia (1970), e freqüentemente não são regularizadas (sem registro em carteira de trabalho), tendo como conseqüência baixa remuneração.

Observou-se relação entre as atividades de trabalho remunerado realizadas pelas mães e o seu nivel de escolaridade. Dado que as ocupações que desenvolviam não demandam escolarização, essas mulheres tinham no máximo completado o ensino fundamental (oito anos de estudo). A única mãe (E3) que desempenhava função de prestígio social intermediário (auxiliar de administração em universidade estadual), apresentava também maior nível de escolaridade (nivel médio).

Dentre as mulheres que não trabalhavam naquela ocasião, o grau de escolaridade era bastante variável.

No que se refere aos chefes de familia, foram reportados os seguintes dados quanto à ocupação. Dos vinte responsáveis, dezesseis desenvolviam atividade de trabalho remunerada e regular por ocasião da coleta de dados. Entre esses, um era empregador, quatro trabalhavam por conta própria, nove eram empregados - um destes estava desempregado há alguns meses - e dois funcionários públicos.

Considerando o tipo de atividade realizada e tendo como referência a Escala de Prestígio Ocupacional proposta por Gouveia (1970), construiu-se o quadro 2 intitulado "Distribuição das ocupações dos chefes de família 
apresentado abaixo, que expõe as classificações das ocupações desenvolvidas pelos chefes de familia.

Quadro 2. Distribuição das ocupações dos chefes de familia, segundo a Escala de Prestígio Ocupacional proposta por Gouveia (1970)

\begin{tabular}{|l|c|}
\hline Classificação das ocupações & $\mathbf{N}^{0}$ de chefes \\
\hline 1. Ocupações manuais não especializadas & $10^{*}$ \\
\hline 2. Ocupações manuais especializadas e assemelhadas & 2 \\
\hline 3. Supervisão de trabalho e ocupações assemelhadas & 1 \\
\hline 4. Ocupações manuais de rotina e assemelhadas & 2 \\
\hline $\begin{array}{l}\text { 5. Posições mais baixas de supervisão ou inspeção de } \\
\text { ocupações não manuais, proprietários de pequenas empresas } \\
\text { comerciais, industriais, agro-pecuária, etc. }\end{array}$ & - \\
\hline $\begin{array}{l}\text { 6. Profissões liberais, cargos de gerência ou direção, } \\
\text { proprietários de empresas de tamanho médio }\end{array}$ & 1 \\
\hline $\begin{array}{l}\text { 7. Altos cargos políticos e administrativos, proprietários de } \\
\text { grandes empresas e assemelhadas }\end{array}$ & - \\
*O chefe desempregado (E14) desempenhava função compreendida nesta categoria antes.
\end{tabular}

Observando-se o quadro, pode-se verificar que pouco mais da metade dos responsáveis pelas famílias (11) desempenhava funções de baixo prestígio social, pertencentes às duas primeiras categorias de ocupação, o que implica baixa remuneração e muitas vezes ausência de vinculo formal de trabalho (sem registro em carteira de trabalho). Outros três (E3, E4 e E20) realizavam atividades que exigem algum grau de escolaridade (I Grau) e gozam de relativo prestígio social, correspondendo a níveis pouco melhores de remuneração.

Apenas um (E15) desfrutava de maior prestígio ocupacional e, consequentemente, maior rendimento, por ser sócio e proprietário de estabelecimento comercial, atividade esta compreendida em categoria de alto prestígio. Cabe destacar que este indivíduo era também o único chefe a ter nível secundário de escolarização. 
Entre os demais chefes não mencionados (4), dois não realizavam atividade de trabalho remunerado e dois se encontravam desempregados. Sobre o último (E5), não foi possivel acessar a informação.

Quanto à escolaridade, dezessete responsáveis (85\%) se encontravam no nivel elementar de ensino, incluidos os sem instrução, tendo apenas quatro deles concluído. Apenas um dos responsáveis havia completado o ensino secundário. Os dois casos omissos se devem a desconhecimento do informante.

Comparativamente, o nível de instrução das mães (média de 7,2 anos de estudo) alcança patamar mais alto que o dos chefes de família (5,4 anos de estudo), cujo conjunto se caracteriza por ser de maioria do sexo masculino (13 homens: 7 mulheres). Tal situação é encontrada na população como um todo em razão da taxa de escolarização feminina permanecer mais elevada (Fundação IBGE 2000).

Apesar do nivel de instrução das mães ser maior, as familias chefiadas por mulheres apresentavam renda menor do que aquelas cujos responsáveis eram homens. Essa desigualdade também é observada na população de um modo geral, pois, embora a participação feminina no mercado de trabalho tenha crescido significativamente, as oportunidades de ocupação de postos mais elevados de trabalho e os patamares de remuneração de homens e mulheres permanecem desiguais, ainda que em menor proporção.

Ademais, tem-se que o número de famílias chefiadas por mulheres é considerável, acompanhando a tendência de aumento dessas últimas observada na Região Metropolitana de São Paulo entre os anos 1994 e 1998 (Fundação SEADE 2002). Tal como entre os paulistanos, nota-se que as famílias cujos responsáveis são do sexo feminino estão com freqüência associadas aos arranjos monoparentais (E4, E6, E10, E14, E16), ou seja, definidas pela ausência do cônjuge. Por razões óbvias, esse tipo de familia acaba por ter um orçamento familiar inferior àquelas onde se encontra o casal presente. 
Em relação à renda, quinze familias percebiam rendimentos inferiores a cinco salários mínimos ao mês, sendo que destas três (E10, E14 e E18) não atingiam sequer a faixa de dois salários mensais. Entre as três famílias restantes, cuja renda foi informada, duas (E11 e E20) dispunham de cinco a dez salários mínimos exclusive ao mês e uma (E15), dez e mais salários.

Também se verificou associação entre o quesito renda, ocupação e escolaridade do chefe da familia no casos extremos, tanto da familia mais favorecida $(E 15)$ quanto daquelas em piores condições materias (E10, E14 e E18).

Buscando oferecer mais alguns elementos a fim de caracterizar as condições de vida das famílias das mães, utilizou-se a metodologia proposta por Chiesa (1999) identificando que: oito mães residiam em áreas identificadas como Grupo Homogêneo I e II, cujas condições eram as mais favoráveis ("boas" e "intermediárias"); duas (E12 e E18) encontravam-se no Grupo Homogêneo III, que apresentava situação regular e ruim; e sete (E2, $E 6, E 8, E 10, E 13, E 17$ e E19) faziam parte do último grupo, o Grupo Homogêneo IV, que corresponde às piores condições com maiores riscos de adoecer. Essas últimas residiam em favelas localizadas no distrito do Rio Pequeno, exceto uma (E17) que se situava no distrito Butantã.

Focalizando o grupo de mães cujos filhos contraíram pneumonia (E2, E8, E9, E14, E19 e E20), observou-se que todas residiam no Rio Pequeno, sendo a maioria (4) natural do interior de outros estados, entre os quais Minas Gerais, Piauí, Pernambuco e Rondônia. De um modo geral, sua escolarização era bastante baixa, não ultrapassando os anos de ensino elementar e tendo apenas uma delas concluído. Metade desenvolvia atividade de trabalho remunerado, desempenhando funções desprovidas de prestígio social e com baixa remuneração.

Os chefes dessas famílias também apresentavam baixa escolarização, não tendo completado o I grau. Além disso, ocupavam-se de atividades de baixo prestígio social, o que se refletia na renda familiar mensal inferior a 5 salários mínimos, salvo um. 


\subsection{Categorias de análise}

Segue-se apresentando os resultados da análise dos discursos maternos acompanhados da discussão pertinente, exceto quando esta é mais ampliada e se aplica ao conjunto dos subtemas de uma categoria. Nesses casos, decidiu-se apresentar a discussão ao final da categoria correspondente.

A partir dos depoimentos das mães, foram construídas duas categorias principais, a saber "Concepções da pneumonia em crianças" e "Práticas de cuidado materno relacionadas à criança com pneumonia". Passa-se então, à apresentação das referidas categorias. 


\subsubsection{Concepções da pneumonia em crianças}

Nessa primeira categoria, estão apresentadas as concepções maternas acerca da pneumonia infantil. Dela fazem parte os seguintes subtemas: "doenças respiratórias conhecidas", "definição de pneumonia", "manifestações clínicas da pneumonia" e "causas da pneumonia".

De início, cabe tecer algumas considerações aplicáveis ao conjunto do material, que puderam ser verificadas nos trechos ilustrativos abaixo apresentados, como também nos discursos reproduzidos ao longo da exposição das categorias de análise.

As mães discorreram sobre a maioria dos tópicos investigados, evidenciando que a pneumonia é um evento de saúde importante no cotidiano de vida da população. Apenas duas mães (E6 e E10) referiram desconhecer maiores informações sobre a temática investigada, apresentando um discurso acentuadamente pobre.

Nota-se que, na população de um modo geral, a temática das doenças desperta significativa curiosidade e interesse nos indivíduos, especialmente quando se tratam de enfermidades que incidem com certa freqüência e que podem acometer qualquer um.

Em seus relatos, o grupo de entrevistadas identificou diversas fontes fornecedoras de informações sobre o assunto. Entre elas encontravam-se: experiências pessoais ou com pessoas próximas, parentes, profissionais da área da saúde e da educação, amigos, vizinhos, companheiros de trabalho, usuários de serviço de saúde, veículo de comunicação de massa e material de leitura.

Houve grande ênfase nas vivências com a pessoa com pneumonia enquanto motivação e oportunidade de aprendizado sobre o tema seja o enfermo o próprio sujeito (a mãe), seu filho, seu parente, ou seu amigo. 
Nesses casos, a proximidade do evento teria viabilizado acesso ao conhecimento, que teria sido depreendido a partir da observação do doente e dos cuidados dispensados a ele.

"Que eu conheço tem a bronquite né, a pneumonia também. Só sei essas duas assim porque a minha irmã teve."(E1)

"Eu pelo menos, quando eu senti (pneumonia), eu senti muita dor nas costas." (E8)

"A doença que eu conheço é a que a minha filha tinha quando era mais nova."(E17)

Para uma mãe (E1), ainda que ela não tenha vivido concretamente uma situação de doença próxima, a simples possibilidade disso ocorrer futuramente já se revelou motivação suficiente para seu aprendizado, por considerar que o conhecimento poderia vir a ajudá-la. Como resultado, apresentou um relato bastante rico a respeito dos cuidados de saúde infantis.

"É que às vezes assim, eu escuto e vou gravando, porque um dia eu posso precisar disso né." (E1)

Os profissionais de saúde, principalmente os médicos, propiciaram importante aquisição de conhecimentos por parte das mães. Os contatos com os médicos se deram em consultas motivadas pela própria pneumonia ou outras afecções respiratórias, bem como em atendimentos voltados para controle de saúde, como pré-natal ou puericultura.

"Através dos médicos. Os médico que ensina a gente. Quando vacê ganha nenê, eles já ensina. Como cuidar, como banhar, como fazer tudo."(E9)

“(como obteve informações) Aqui no CSE”. (E10)

"E pelos médicos também né. Por causa dessa respiração (ruidosa) dele, eu já levei ele várias vezes nos médicos assim preocupada né. (...) Aí os 
médico vão falando né. Vim tanto no médico que eu vou aprendendo aos poucos." (E11)

Familiares com diferentes graus de parentesco também foram mencionados, entre eles pais, sogra, irmã e cunhada, ocupando posição de destaque os avós da criança. É compreensível que os parentes, particularmente os avós, sejam uma referência para as mães, pois, por um lado, representam a história, as tradições e a origem materna ou paterna e, por outro, mantêm uma relação habitualmente permeada de afeto com a mãe e a criança.

Os familiares de gerações anteriores, como é o caso dos avós da criança, contribuíram fundamentalmente para o ensinamento de costumes e tradições relacionados ao cuidado infantil. Acredita-se que os avós tenham feito maior uso e, por isso, transmitam essas crenças e práticas populares, porque viveram numa época e local em que a medicina incorporava muitas delas por falta de acesso a outras. Ademais, sendo a cidade de São Paulo um pólo que vem atraindo migrantes de diversos estados do Brasil, vários deles são oriundos de regiões onde o acesso aos serviços de saúde era, e talvez ainda seja, restrito. De acordo com Loyola (1984), onde há falta de equipamentos oficiais de saúde as relações interpessoais são mais fortalecidas pela solidariedade, pois é o único recurso existente.

Assim sendo, a escassez ou mesmo ausência de contatos com os médicos, que são os principais difusores do conhecimento médico, acaba por implicar uma concepção de saúde e doença mais antiga, onde não se encontram presentes elementos que a ciência médica colocou à disposição em passado recente.

"Não sei, muitas pessoas da antiga recomendam xaropes. Não sei, minha sogra faz uns xaropes... "(E3)

"Meu pai me sugeriu. Ele mora lá em Minas né. Eu liguei para ele, ele falou: 'Filha dá (xarope caseiro) para ela (filha doente)'." (E8) 
"Pela minha cunhada também né, porque a gente sempre conversa muito. Então, como a gente teve nenê praticamente juntas, então tudo ela vai falando, passando para mim né. $O$ que eu sei, eu passo para ela." (E11)

Além das referidas fontes informativas, diversas pessoas do círculo de relacionamento da mãe contribuíram para a ampliação de seu conhecimento, oferecendo noções sobre a doença e sugestões para tratamento da criança. Dentre essas pessoas foram destacadas: profissionais da saúde e da educação, parentes, amigos, vizinhos, companheiros de trabalho e usuários de serviços de saúde.

"Pelo menos os meus vizinhos falaram, não os médicos, os meus vizinhos falaram: 'olha você tem que dar o remédio certo, porque senão a pneumonia pode voltar'. Isso foi o que eles falaram para mim: 'se não der o remédio certo...' É uma menina que trabalha aqui mesmo na creche né, então ela cuida de um monte de criança. (...) Isso foi informação que recebi da minha vizinha."(E8)

"(obteve) Umas (informações) de consulta (médica), outras porque uma pessoa vai para consulta e conta."(E13)

"A minha irmã né, que eu falei a minha irmã teve pneumonia, então sempre comentava comigo."(E19)

"(quando o filho estava com pneumonia) Muita gente assim: eu falava, o pessoal lá no serviço (local de trabalho) falava e assim os vizinho sempre ensina assim esses remédios. "(E19)

"Eu acho que como ela (filha) teve (pneumonia), então todo mundo sabia né. Aí um vinha falava uma coisa, o médico também né, amigo falando e assim eu fui aprendendo né. Um falava uma coisa, outro falava outra e eu fui aprendendo né." (E20) 
Tais pessoas ofereceram às mães informaçōes baseadas na ciência médica, embora estas se apresentassem algo deformadas em função das re-interpretações sofridas no processo de assimilação.

Apenas duas mães reportaram terem se utilizado de outros recursos informativos, quais sejam: material de leitura e televisão. Talvez, se entre os sujeitos entrevistados houvesse pessoas com nivel de escolarização mais elevado, o recurso à leitura fosse mais freqüente. De qualquer forma, tanto um como outro poderiam ser mais empregados como difusores de conhecimento sobre as IRA na infância.

“...e outras (informações) por ler. Eu adoro ficar lendo as coisas.”(E13)

"Sempre também eu assisti televisão e eu vi esses casos também na televisão."(E14)

$\mathrm{O}$ argumento da experiência serviu tanto às mães que dispunham de informações, quanto àquelas que declaravam desconhecimento. A ausência de experiência teria colocado algumas mães em situação de prescindir dos conhecimentos sobre pneumonia por serem desnecessários e não aplicáveis em seu cotidiano. Desse modo elas justificavam seu desconhecimento sobre o tema.

"Ai, eu não sei, eu não sei explicar. Eu nunca vi ninguém, não conheço ninguém que tenha tido pneumonia. (....) Mas só ouvi falar né. Na minha família mesmo ninguém nunca teve, eu não sei explicar como que é. Na minha familia ninguém teve ainda, então eu não sei."(E6)

"Não, porque eu nunca me interessei né porque meus bebês nunca tiveram né."(E10)

"Eu falo que eu não sei responder porque ele (filho) ainda nunca teve né. Então, eu não sei responder direito essa pergunta. Porque se ele tivesse tido, aí eu já ia saber responder. Porque tipo assim, quando ele 
está resfriado, eu já sei os primeiros sintomas dele (...) Agora, a parte de pneumonia, eu não sei explicar. "(E16)

"Aí você me pegou, que eu não sei. Lá em casa ninguém nunca teve, a não ser minha sobrinha que teve bronquiolite."(E17)

"Não sei. Como nunca aconteceu em casa, então não tenho aquela experiência".(E18)

Outro motivo apresentado para explicar a ausência ou escassez de conhecimento sobre o assunto foi o não fornecimento de informações completas por parte de profissionais da saúde, com destaque para os médicos.

"Não sei, porque dai eles (médicos) não fala para a gente né. Só fala que está com pneumonia, mas eles não fala de onde vem (as causas)."(E8)

No entanto, não se pode afirmar que o discurso materno corresponda à realidade dos fatos e que a mãe $(E 8)$ não disponha de maior conhecimento em razão de falha de comunicação dos profissionais. Não se está com isso colocando em dúvida o relato apresentado, mas sim fazendo a necessária distinção entre as representações mentais que os sujeitos fazem dos fatos e a realidade concreta e objetiva.

Muitos são os fatores que podem influenciar a percepção dos sujeitos acerca dos fenômenos. Nesse sentido, na fala citada abaixo (E20), há o reconhecimento de que o estado emocional da mãe bastante perturbado diante da necessidade de hospitalização do filho poderia estar prejudicando sua compreensão sobre os fatos.

"Não sei, (os médicos) não falaram isso (motivo da internação). Só mostraram lá e falou 'Ó mãe, tem uma mancha aqui, é uma pequena'. Porque lá (no hospital) não explicam assim né. Não vai falar 'é pneumonia mesmo'. Não sei se é para não fazer medo, não sei porque eu também estava em pânico".(E20) 
Embora se possa pensar o contrário à primeira vista, quando ocorre a hospitalização, os contatos entre doente, seus familiares e o médico ficam ainda mais dificeis. Segundo Boltanski (1989), isso se deve em parte aos intermediários que se colocam entre eles, acentuando a ansiedade dos primeiros em relação à doença e à terapêutica. No depoimento que se segue, as dúvidas persistentes da mãe em relação aos problemas de saúde de sua filha, atendida diversas vezes em serviço hospitalar, ilustram a idéia acima apresentada.

"Ela (filha) já foi umas quatro vezes (para o Hospital Universitário).É, direto eu vou né. Ela fica, toma inalação. Passo a noite inteira na observação. (O médico) Acha que não é muito grave né, aí manda para casa. Aí, em casa, eu fico fazendo em casa inalação. Eles (médicos) nunca falaram (se a filha teve pneumonia), eu que penso né. Acho que a pneumonia mesmo só foi essa vez que ela ficou internada."(E20).

Outra mãe (E10) também revelou ter tido um entendimento equivocado quanto à (in)disponibilidade dos profissionais do serviço de saúde para esclarecerem suas dúvidas sobre os problemas de saúde de seu filho. Julgando que não seria acolhida no CSE, ela procurou outro serviço, hospitalar no caso. Neste último, sim, foi repreendida pela iniciativa sob a alegação de que lá a criança estaria em situação de risco a sua saúde e de que esta era uma função dos profissionais da unidade básica.

É que uma vez ele ficou, ele estava com resfriadinho, roncando né, assim que o pai dele já faleceu. Aí eu fiquei um pouco assustada. Ai eu levei na USP e os médico não gostaram, que lá podia pegar infecção e que sempre que tivesse algum probleminha não tivesse dúvida em procurar o posto de saúde. Que eu falei 'ah, mas eu fiquei com medo de ir lá e as médica não gostar né. Só por causa disso'. Ela (profissional do hospital universitário) falou: 'Não, mas os médicos estão lá para atender, eles vão te atender bem'. E a (profissional do CSE) que visita em casa, ela falou 'qualquer probleminha, qualquer dúvida que você tiver a respeito, pode procurar nós, nem que seja para alguma informação'.(E10) 
Não se pode deixar de reconhecer que diversas vezes os profissionais de saúde adotam uma postura prescritiva e pouco receptiva às mães, fazendo com que elas se constranjam e não explicitem suas demandas. São também freqüentes as queixas de mutismo e de emprego de vocabulário técnico especializado por parte dos médicos, incompreensivel muitas vezes.

Fazendo uma análise sociológica da relação e da comunicação entre médico e cliente, Boltanski (1989) acrescenta alguns elementos que podem ajudar na compreensão desse fenômeno. Segundo esse autor, os médicos dão explicaçōes conforme a classe social do cliente e a representação que têm dos mesmos. Assim, os membros das classes populares, vistos preconceituosamente como ignorantes, são julgados incapazes de compreender a linguagem e as explicações médicas e, portanto, a eles são dirigidas apenas ordens sem comentários em lugar de recomendações argumentadas.

Assim, talvez o fato das mães entrevistadas pertencerem em sua grande maioria a grupos sociais menos favorecidos tenha marcado sua relação com os profissionais que, mantendo uma conduta reservada no que toca ao fornecimento de informações, acabam por restringir as oportunidades de aprendizado materno.

$\mathrm{Na}$ tentativa de justificar o desconhecimento materno, foi alegado também esquecimento. Chama a atenção que a dificuldade de lembrar das informações é referida tanto por uma mãe (E2) cujos dois filhos já apresentaram dois episódios de pneumonia cada um quanto por outra (E10) que nunca teve esta experiência. O discurso da primeira se revelou bastante limitado no que toca às concepções e às práticas junto à criança com pneumonia.

“Já estudei muito, mas eu estou muito esquecida."(E2)

"Mas tem muita coisa que eu num lembro na minha memória."(E2) 
“Já (ouvi falar), mas não guardo. Não me lembro. "(E10)

À primeira vista, poder-se-ia apontar a existência de uma contradição nesse caso, uma vez que a experiência foi tantas vezes ressaltada como motivação e oportunidade de ampliação dos conhecimentos sobre o assunto. Entretanto, analisando a questão com maior profundidade, pode-se afirmar que seja exatamente o fato da mãe ter uma compreensão limitada acerca do tema que poderia estar contribuindo para a ocorrência dos sucessivos e recorrentes agravos à saúde dos filhos. São a elevada incidência dos agravos e o prejudicado entendimento acerca dos mesmos frutos das precárias condições de vida material desta mulher e familia, expressas no baixo nível de escolaridade dos pais, na baixa renda familiar mensal, na moradia em favela e no dificil acesso aos serviços de saúde (não faz controle de saúde dos filhos e as imunizações do mais jovem se encontram desatualizadas).

De acordo com Berlinguer (1987), "quem é pobre morre antes" e a justificativa para isto reside na subalimentação, na falta de higiene, nas condições precárias de moradia, na exploração, na ignorância, no desemprego, enfim, nas condições que definem a situação daqueles que vivem na pobreza e são vítimas dela. As doenças não podem mais ser consideradas como um fenômeno puramente biológico. Segundo este autor, elas são distintas em função das épocas, das regiões e dos estratos sociais, "porque são resultantes do modo como o homem se relaciona com a natureza (da qual é parte), através do trabalho, da técnica e da cultura, isto é, através de relações sociais determinadas, e aquisições cientificas historicamente progressivas".

Foi possivel também observar certo grau de insegurança ou incerteza materna na abordagem ao tema. Com freqüência, elas mostravam preocupação em esclarecer que suas respostas poderiam ser insatisfatórias por estarem incorretas, imprecisas, ou incompletas, alertando insistentemente para sua ignorância. 
“Agora mais, eu não sei não. Só sei essas duas (doenças) assim. "(E1)

“Ah, bastante jeito (de proteger a criança contra pneumonia), mas agora quais assim eu não sei. Eu não sei explicar sabe, mas eu sei que tem que proteger bastante." (E1)

"E que mais, sei lá, só isso."(E2)

"Então, mas assim bem dizer, eu não sei bem dizer o que é (pneumonia) mesmo."(E8)

“É, eu não sei muito bem."(E13)

“Mas o que eu sei assim ainda é nada."(E15)

"Olha, eu não sei explicar o que é que é uma pneumonia. Mas deve ter mais coisas além do que eu estou falando."(E16)

“Apesar de eu não saber muita coisa, porque eu não sei mesmo. Eu não sei nem porque que pega realmente, que você me perguntou e eu não sei né."(E20)

"É só isso que eu sei. Eu não sei muito não." (E20)

Tal constrangimento e insatisfação em relação às informações expressas talvez sejam resultado das mães terem sido solicitadas a discorrer a respeito de um tema - a pneumonia - sobre o qual não tinham domínio. As concepções sobre doença podem representar um conhecimento de maior complexidade e mais distante de seu universo representacional por incorporarem elementos que escapam aos campos de saber popular, acarretando maior dificuldade de entendimento e, portanto, maior incerteza.

Boltanski (1989) acrescenta que, sendo hoje as doenças consideradas um conhecimento científico cuja legitimidade pertence ao médico, não se espera que outros tenham domínio dele. Sendo assim, as próprias mães não se percebem autorizadas a acessar um conhecimento, que é por direito de posse dos especialistas. 
Por essa razão, elas não se sentem livres para desenvolver um discurso sobre a doença. Suas tentativas de explicação são com freqüência seguidas de uma constatação de ignorância. Quando empregam um termo médico, o fazem com certa vergonha, pois a palavra permanece estranha, sem se integrar à sua linguagem. $E$, ao fazê-lo, mostram claramente que se está tomando emprestado da ciência um termo que não pode ser usado ilegitimamente, dizendo "os médicos falam que".

Então, não se pode deixar de pensar que a negativa em fornecer algumas informações, sob a alegação de desconhecimento ou desinformação, pode ter sido na verdade, uma estratégia de preservação pessoal das mães. Dessa forma, elas evitaram o constrangimento de se expor de forma indevida ou inadequada sobre algo que thes parecia vago ou duvidoso, ou ainda de se mostrarem desrespeitosas e pretensiosas em relação à complexa ciência médica, a qual não estão autorizadas a acessar.

Também sob esse ângulo, os discursos das mães com e sem experiência se revelaram indiferenciados. Como foi possível verificar nos exemplos acima, ambas manifestaram insegurança e constrangimento relativos às suas manifestações, contrariando a idéia de que a experiência resultaria em maior domínio sobre a temática estudada.

Assim, embora sejam usuárias de serviço de saúde (CSE, entre outros) e atualmente $o$ atendimento médico seja o principal difusor do conhecimento médico, as mães apresentam um discurso pouco eloqüente para falar de doença e enumerar seus conhecimentos médicos. Boltanski (1989) assinala ainda que a situação de pesquisa produz com mais força hesitações na elaboração de um discurso coerente e elaborado sobre a doença, porque reaviva a consciência sobre a existência de um saber médico legítimo.

Por outro lado, a pesquisa fez aflorar a receptividade das mães (E19 e E20) em relação ao assunto, que se manifestou através da solicitação de 
esclarecimentos referentes a diversos tópicos abordados na entrevista. Não se sabe se a demanda era anterior ou foi gerada pela pesquisa. De qualquer forma puderam expressá-la, talvez porque vislumbraram uma possibilidade de suprí-la.

Feitas análises e considerações referentes à origem dos saberes maternos, passa-se à apresentação dos subtemas contidos na categoria "Concepções da pneumonia em crianças".

\subsubsection{Doenças respiratórias conhecidas}

Buscando verificar se as mães tinham algum conhecimento prévio sobre a existência da pneumonia, indagou-se sobre as doenças respiratórias conhecidas. Mediante tal solicitação, constatou-se que elas podiam citar várias delas espontaneamente. Entre as afecções lembradas, estavam: resfriado (1), câncer (2), rinite (2), afecções da laringe (2), tuberculose (2), asma (5), pneumonia (8) e bronquite (9), sendo as três últimas as mais citadas.

"Ah, que eu conheço tem a bronquite né, a pneumonia também. Ai, agora mais, eu não sei não. Só sei essas duas assim. (...) Também tem aquela bronquite de pó né. Não sei como que fala. Bronquite asmática que fala né?"(E1)

“De câncer né."(E2)

“(Conheço) Bem pouco. Num sei... É que o resfriado também é uma doença assim. Então, só o resfriado. Ah, sim, tuberculose, a pneumonia que é pulmão também e acho que é só." (E3)

"A asma né, que acho que é a mais comum." (E4) 
“Conheço. Tem a bronquite."(E5)

“É bronquite, essas coișas né (...) É, tem a pneumonia, tem um monte né."(E7)

"Eu conheço, como tive bronquite né. Bronquite, eu sei que é respiratória porque ataca os pulmão. Agora... Tuberculose né. Asma né, eu não sei se é o mesmo que bronquite. Só. Que eu sei só isso. "(E8)

"Bronquite, asma, é... pneumonia né, que dá problema também. Ele tem um probleminha na respiraçãozinha dele que não sei se é... Como que fala? Essa parte (região da fúrcula) assim dele assim não é formada assim né ... Laringe, não sei." (E11)

"Ah, eu... Essas de bronquite, pneumonia... É... Ah, não sei."(E12)

“Asma, bronquite, pneumonia. É, são as que eu conheço né."(E13)

"Bronquite, laringite aguda, pneumonia. Acho que essas. Por enquanto só." (E15)

"Pulmão já ouvi falar bastante. É mais é sobre câncer né, que hoje em dia é o que está mais falado. Além disso, pode ter mais doença, mas eu não sei né."(E16)

"Bom, é a pneumonia né e... Agora, o outro meu menino, ele tem problema de rinite também, rinite alérgica e ele cansa também. Asma né, bronquite. Acho que é só que eu conheço."(E19)

Apenas por este levantamento, foi possivel perceber uma compreensão materna limitada sobre as doenças respiratórias no seu conjunto. Elas demonstraram ter dúvidas quanto aos nomes designados a algumas das enfermidades, como também em relação à distinção entre umas delas.

De um modo geral, a maior parte dos agravos mencionados pelas entrevistadas pertencem ao grupo das afecções de vias aéreas inferiores. 
Acredita-se que a ênfase dada a esse grupo de doenças se deve à associação estabelecida entre "doença respiratória" e problemas que afetam a respiração ou mais especificamente os pulmões, órgão identificado como responsável pela função. Tal associação também pode ser resultado do fato da pesquisadora ter empregado por vezes a expressão "doença de pulmão", visando estimular as emissões das mães que responderam negativamente às doenças respiratórias conhecidas.

A freqüência com que foram lembradas bronquite (9), pneumonia (8) e asma (5) é coerente com o destaque que as mesmas assumem no perfil epidemiológico da população infantil. A bronquite e a asma têm sua importância expressa nos elevados índices de morbidade e no fato de produzirem um quadro respiratório que preocupa e exige vários cuidados infantis, além de aumentar significativamente a susceptibilidade da criança às infecções respiratórias baixas. Estima-se que cerca de $10 \%$ da população sofra de asma, que é uma das doenças crônicas mais comuns na infância (Ribeiro 1987; Naspitz et al. 1987).

Já a pneumonia, ainda que menos freqüente, é relevante, pois responde por elevados índices de hospitalização e mortalidade em nosso meio. Conforme foi dito em capítulo anterior, dentre os menores de 1 a 4 anos, as pneumonias constituem-se a principal responsável no grupo de doenças do aparelho respiratório que, por sua vez, ocupam o primeiro lugar entre as causas de óbito em crianças, tanto no âmbito municipal quanto no estadual. Tal fato se justifica pela maior proporção de casos graves (Graham 1990), decorrente da acentuada desigualdade social existente e de seu impacto nas condições de saúde da população nos países em desenvolvimento (Yunes e Díaz 1997).

Afecçōes do trato respiratório superior tais como amigdalite e otite, têm alta probabilidade de serem conhecidas pelas mães entrevistadas exatamente porque incidem muito, mais do que algumas das enfermidades lembradas. Entretanto, podem não ter sido reportadas pelas razões 
apresentadas anteriormente, que suscitaram preferencialmente a memória dos agravos das vias aéreas inferiores.

De qualquer forma, ficou evidente que a pneumonia, ao lado de outras doenças que acometem o trato respiratório, era amplamente conhecida pela maior parte dos sujeitos que participaram da pesquisa. Mesmo quando não haviam mencionado espontaneamente a pneumonia entre as doenças respiratórias conhecidas, ao serem perguntadas diretamente, todas as mulheres referiram ter conhecimento dela previamente.

Cabe assinalar que o conhecimento aqui destacado se refere apenas à nomeação da enfermidade. Em relação a isso não se pode ignorar o fato de que as informantes eram pessoas que freqüentavam o CSE para atendimento dos filhos, o que pode ter contribuido para que as denominações dos agravos respiratórios fossem de algum modo familiar a elas. $O$ acesso ao conhecimento poderia ter resultado tanto de informaçōes fornecidas pelos profissionais do serviço quanto das oportunidades de troca de experiências entre os usuários.

\subsubsection{Definição de pneumonia}

A pneumonia foi descrita de forma sucinta pelas mães. Examinando as definições oferecidas separadamente, nota-se que se apoiavam em alguns poucos aspectos, excluindo outros. No seu conjunto, as concepções apresentadas reuniram diversos elementos, mostrando-se mais abrangentes.

Cabe comentar ainda que os elementos componentes das descrições maternas tenderam a restringir-se àqueles presentes no senso comum, extraídos da ciência médica de forma fragmentada e descontextualizada. 
Passando à apresentação das definições maternas de pneumonia, tem-se que é considerada uma doença curável. Melhor dizendo, há o entendimento de que a criança tem possibilidade de se recuperar através de tratamento uma vez que tenha sido acometida por ela.

"Pneumonia assim é uma doença assim que dá para curar, mas demora.(E1)

"Está gripada, deu as pneumonia e vamos curar."(E9)

"Dizem que tem como tratar."(E16)

Contudo, conforme é possivel constatar nos exemplos apresentados acima, a cura é colocada na dependência dos cuidados dispensados ao doente, isto é, a pneumonia tem possibilidade de cura, mas demanda cuidados para tanto. Entre os cuidados voltados para a recuperação da criança doente, foram lembrados: a busca de atendimento médico para o enfermo, a administração correta de medicamento e a manutenção da criança aquecida, evitando seu resfriamento mediante banho rápido.

Inversamente e reforçando ainda mais a importância atribuída aos cuidados, a não observância dos mesmos é apontada como responsável pelo agravamento da doença, podendo levar a criança a óbito. A pneumonia é vista como uma enfermidade perigosa, pois pode causar a morte da criança afetada. Por esta razão, merece toda atenção por parte do responsável ou cuidador infantil.

"Ai tem que ter muito cuidado com a pneumonia"(E1).

"Pneumonia... é... como fala meu Deus do céu. É capaz da criança morrer né. Tem cuidados né, para não dar disso ai. "(E2)

“(...) que pode levar à morte, se não cuidar. (...)E tem que tomar os cuidados, porque se não..."(E5)

"É preciso sim de tratamento. Precisa né, senão acaba morrendo né." (E6) 
"Pode até matar dependendo da pneumonia."(E11)

"Eu sei que pneumonia é uma doença grave né."(E15)

A noção de gravidade associada à pneumonia está apoiada num sistema de classificação das doenças, onde umas são vistas como leves ou benignas e outras graves, conforme o risco que oferecem à vida do indivíduo. Então, a pneumonia é percebida pelas mães como grave, em razão de se constituir importante causa de hospitalização e óbito em crianças na nossa realidade.

Os cuidados à criança enferma foram bastante valorizados pelas mães, que Ihes conferiram o poder de definir o prognóstico da criança com pneumonia: a realização dos mesmos de forma adequada viabiliza a recuperação da saúde e, consequentemente, a sobrevivência infantil; ao passo que a sua ausência, insuficiência, ou inadequação determina a morte da criança doente. Portanto, em última instância, há o entendimento de que a doença em questão representa uma forte ameaça à vida da criança e é passível de ser combatida tão somente através de cuidados apropriados, rigorosamente prestados a ela.

Particularmente no caso das mães que já tiveram um filho acometido por pneumonia, tal caráter ameaçador fez com que o episódio de adoecimento infantil tenha sido vivido acompanhado de certo temor. Essa percepção acaba por resultar em atribuição de importância ainda maior aos cuidados infantis, bem como em maior empenho da mãe na sua realização.

"Eu tinha medo. Ai. Sei lá! Os outro diz que se não cuidar direito assim de uma pneumonia, a criança pode até morrer. Ai, eu sempre tive medo. Minha mãe, minha mãe sempre disse. Sempre também eu assisti televisão e eu vi esses casos também na televisão. Que era perigoso mesmo. E outra, qualquer doença hoje que aparece não é de brincadeira né, tem umas que leva até para morte, mesmo. Ai eu sempre cuidei."(E14) 
“Eu acho que é uma doença perigosa né. Se a gente não tratar direito... Já vi muitos casos né, que a pneumonia mata né. É muito perigosa. Tem o máximo de cuidado para isso. (...) Esse aqui teve começo de pneumonia e eu fiquei com medo né. O outro também. "(E19)

Ainda no que diz respeito aos cuidados maternos demandados pela criança doente, apreende-se que são vistos como de responsabilidade materna', conforme as falas atestam ("uu sempre cuidei", "se a gente não tratar direito"). Esta noção de que o cuidado dos filhos cabe à figura da mãe repousa no ideal de maternidade vigente no pensamento coletivo na atualidade. Tal questão será aprofundada ainda nesta categoria, em subtema posterior referente às causas da pneumonia.

Vista sob um outro ângulo, a doença foi definida como um mau funcionamento orgânico, mais especificamente localizado nos pulmōes. $O$ conhecimento expresso se restringiu ao reconhecimento de certas características observáveis na pessoa portadora de pneumonia e à reprodução de expressões de cunho médico, sem parecer haver maior compreensão sobre elas.

"Para ser sincera, eu sei que é um acúmulo de catarro no peito né, mas como que ocorre mais a fundo, eu não conheço. "(E3)

"Pneumonia para mim hoje é catarro nos peito, pulmão. Envolve pulmão, respiração, chiado, chieira no peito. "(E5)

"Pelo que eu ouvi falar, é uma tosse, que tem que tomar bastante cuidado. Atinge o pulmão."(E7)

"Eu sei que ela (pneumonia) também ataca o pulmão né. Ah, os médico fala que é uma mancha no pulmão né, mas eu não sei bem dizer o que é. Mas eles fala que é secreção no pulmão né. Só sei que ataca o pulmão, é problema no pulmão. "(E8) 
"E já a pneumonia, já é aquele catarro mesmo. Tanto que os médicos fala: "quando sai catarro do nariz da criança, é claro ou é escuro?". Aí, no caso, o Pedro Henrique já saía aquele catarro escuro, meio amarelo, meio forte mesmo. Então, eu já sei. Aí, é diferente né, é bem diferente." (E8)

“Eu sei que é um problema respiratório né."(E11)

"Eu sei que é uma tosse mais grossa né, uma coisa diferente. A diferença de uma tosse normal para a da pneumonia eu não sei não."(E12)

"Quando o peito está cheio de catarro né e não dá para a criança ficar respirando, não dá. Fica com falta de ar. É, com muita dificuldade. Aí, fica vermelha as criança e tossindo."(E13)

"Eu acho que é água que dá no pulmão"(E14)

"Pelo que eu ouvi falar é uma tosse, atinge o pulmão."(E17)

Conforme se pode notar nos discursos maternos exibidos acima, a descrição do problema permaneceu ainda vaga, confusa e permeada de dúvidas. As informações apresentadas se mostraram desarticuladas e, aparentemente, destituídas de sentido. E os mecanismos fisiopatológicos de produção da doença permanecem desconhecidos. Com base nisso, pode-se afirmar que o universo da pneumonia é pouco conhecido pelas mães.

Discorrendo sobre o processo de construção dos discursos sobre doença pelas classes populares, Boltanski (1989) esclarece que os sujeitos tomam do discurso médico os termos que permitem uma descontextualização conservando um sentido. Isto é possível para os termos médicos que passaram a fazer parte da linguagem comum e para aqueles que evocam palavras da linguagem coletiva pelo seu valor simbólico expressivo. De posse dessas expressões, o indivíduo procura elaborar um discurso coerente, atribuindo um novo sentido às palavras (reinterpretação) e preenchendo o vazio que existe entre elas. 
$\mathrm{Na}$ construção das representações de doença, o trabalho consiste em transformar o desconhecido em familiar, através da inscrição do novo no sistema de representações existente. Consiste em substituir o sistema de categorias científicas por uma classificação fabricada com elementos e meios de que dispõe, levando em conta as características aparentes e imediatas das coisas (Loyola 1984).

Arialisando o conjunto de elementos que compõe as concepções maternas acerca da pneumonia, evidencia-se forte influência dos conceitos presentes no paradigma cartesiano.

Conforme Vilela (1996), o paradigma cartesiano (Descartes, 15961650) domina a ciência há três séculos, tendo influenciado todas as áreas do saber. Constitui-se as raizes da base conceitual da ciência médica moderna, resultando no modelo de assistência à saúde denominado Modelo Biomédico. Na medicina, o modelo biomédico adquiriu status de dogma, sendo incorporado ao sistema de crenças culturais da população.

Os conceitos que subjazem tal modelo são: "o corpo humano é considerado uma máquina que pode ser analisada em termos de suas peças; a doença é vista como um mau funcionamento dos mecanismos biológicos, que são estudados do ponto de vista da biologia celular e molecular; o papel dos médicos é intervir, física ou quimicamente, para consertar o defeito no funcionamento de um específico mecanismo enguiçado" (Capra 1987, p.116).

Essa visão mecanicista e reducionista de saúde e, conseqüentemente, de doença, perde de vista o ser humano em sua totalidade, negligenciando os aspectos psicológicos, sociais e ambientais da doença. O tratamento é dirigido à anormalidade biológica (corpo) com ênfase nos medicamentos e não considera o potencial curativo natural do organismo humano. 
A medicina moderna deixa de ser a arte de curar para se tornar uma ciência das doenças. Ao invés de teorizar sobre saúde, vida ou cura, questões estas que passaram a ser vistas como metafísicas, a medicina se ocupa cada vez mais de estudar as entidades mórbidas (Luz 1988).

A atual concepção de saúde, que se limita à compreensão dos processos biológicos, não possibilita uma abordagem prática eficaz dos problemas, reforçando a idéia de que a sua resolução está centrada nas ações curativas e individuais. Isso não se modificará enquanto não houver uma ampliação da estrutura conceitual incluindo as dimensões individuais, sociais e ecológicas, que interagem de maneira complexa na determinação das condições de saúde da população.

\subsubsection{Manifestações clínicas da pneumonia}

Mediante solicitação de referência aos sinais e sintomas apresentados pelas crianças com pneumonia, as mães descreveram um quadro clinico bastante amplo, abrangendo dados objetivos e subjetivos. Essa riqueza de dados é esperada uma vez que as manifestações clínicas que caracterizam os casos de pneumonia infantil são muitas e podem se apresentar em graus de intensidade bastante variáveis, na dependência de diversos fatores como idade da criança e agente microbiano, além das próprias diferenças individuais.

Foram mencionados pelo menos uma vez os seguintes sinais e sintomas: mal-estar geral, irritação, choro intenso, "moleza", febre, freqüência cardíaca aumentada, prostração, não consegue mamar ou comer, coriza, dificuldade para respirar, tosse, cansaço, falta de ar, catarro 
nos pulmões, ruídos pulmonares (sibilos e roncos), dor torácica e retração de fúrcula.

"Ela fica assim enjoada, fica assim muito irritada, não consegue respirar direito assim. E quando respira também, a pneumonia provoca um pouco de tosse. E ai vai ficando meio enjoada, vai perdendo assim a mania de ficar alegre. Vai ficando mais doentinha. A gente percebe pelo rostinho né, meio caidinho assim, não dá aquele sorriso como dava antes. Vai ficando meio doentinho, sabe. Ai, só fica chorando, só. (...) Ela fica assim chorando, chora sem parar. (...) Ela fica mexendo muito a cabeça, querendo respirar assim bastante, mas não consegue. Então, aí ela começa a ficar irritada e chora, chora, chora."(E1)

"Fica meia cansada. E fica meia enjoada, chorando. Dá febre. Não quer saber dos pais né. Da mãe só quer saber, só da mãe. E só, só isso."(E2)

"Acho que febre. Febre, acho que sim. O peito cheio, carregado também, de catarro né. Moleza, que dá moleza também. Acho que só. "(E3)

"Bom, eu acho, não sei, posso estar enganada. Eu acho que desde febre, cansaço né, o peito fica chiando, o coração acelera. Isso que eu ouço falar e que eu... É mais isso, essas coisas aí. E a criança fica caída né. A criança ativa fica quietinha, não brinca como normalmente brinca. É, fica mais no colo, dorme muito, dorme bastante, mais isso. "(E4)

"Eu acredito que febre altissima, que vai e volta, vai e volta. E pode queixar também do peito chiar. É chiado no peito."(E5)

"Tem febre né. Febre. As febre começa, a gente dá o remédio e volta. $E$ eu pelo menos, quando eu senti, eu senti muita dor nas costas, quando respirava sentia dor. Então, para mim, são esses sintomas. Ele (filho) chorava bastante. Ele não me reclamava porque ele não sabia falar, mas ele chorava bastante. Ele tossia, ele tinha catarro nos peito, isso aí eu sei que ele tinha. Que eu lembro só isso." (E8) 
"Ela (filha) estava chiando muito no peito, cansada e falta de ar. E muita febre, febre de 39,38 . E chorava muito." (E9)

"Se eu me lembro bem, eu acho que é através do pulmãozinho né. Fica roncando. Aquele roncando forte. Que eu lembro é só isso." (E10)

"Ah, ficar cansada, ter febre, é... dificuldade para respirar, ronca também né, as costinhas. Apesar que ele ronca desde que nasceu e não tem."(E11)

"Só dá tosse mesmo, que fica uma tosse muito seca. Depois aí, eu acho que já é mais grave."(E12)

"O peito dela fica chiando quando ela está dormindo, chia. Também não consegue mamar direito a mamadeira. Também pode ter febre às vezes. Acho assim né."(E13)

"Chiadeira no peito, cansaço, febre alta, a criança acho que vai ficando mole. Não comer, tossir bastante. "(E15)

"Olha, o que eu conheço, o que eu vejo por aí que eu também... A minha irmã também teve pneumonia e ela falou assim que dói. Ele (filho) cansa né. Aí dói aqui (face anterior do tórax) e aqui atrás nas costas quando a gente tosse. E cansado, ele fica muito cansado né. Eu vejo assim, ele fica sem respirar direito, fica cansado. Eu vejo, eu vejo o pescoço aqui (região anterior) também né, eu olho muito aqui nele. Fica assim, entrando assim e saindo assim. Se ele tiver assim e com febre assim. A febre também. É isso. Acho que só isso mesmo. "(E19)

"Ela (filha) fica muito assim mole assim, fica com febre. Dá febre né e ela fica só querendo dormir, aquela moleza. E ai, tossindo né."(E20)

Febre foi o sinal clínico lembrado com maior freqüência (12 mães), seguida de estado geral ruim (8), dificuldade para respirar/cansaço/falta de ar (8), tosse (8) e ruídos pulmonares (7). Como mau estado geral, a pesquisadora considerou os achados descritos através de diversas 
expressōes que significavam desconforto ou mal-estar, entre elas "fica enjoada" ou "caída", "fica chorando", "não brinca como normalmente" e "fica mole".

Quase a totalidade dos estudos sobre conhecimentos e práticas de saúde populares revela que a febre se constitui o principal sintoma de doença infantil. $E$ freqüentemente sua intensidade e recorrência são utilizadas para distinguir doenças leves de doenças graves.

Nota-se que os sinais descritos são aqueles mais evidentes, facilmente observáveis na pessoa doente. Tal fato revela que o conhecimento materno acerca da pneumonia é construido em grande medida a partir de suas experiências concretas, constituindo-se um conhecimento prático.

Ao discorrer sobre os sinais presentes na criança com pneumonia, uma das mães (E14) mencionou febre e ponderou que a mesma é observada na vigência de outras doenças infantis também. Refletindo mais sobre a questão, disse que a febre é um sinal que não permite distinguir uma doença entre outras, sendo comum a várias.

"Bom, os meus (filhos), o primeiro sinal deles é a febre. A febre e a tosse seca. Aí eu já desconfio. Nem toda vez, porque às vezes é infecção de ouvido ou então infecção na garganta. Que nem, ele agora está com febre, febre alta. Ai o doutor examinou, falou que a garganta dele já está "meia" vermelha. Então, daqui para frente pode ser infecção de garganta."(E14)

A febre e o mau estado geral da criança são observados em muitos casos de pneumonia, porém acompanham várias outras enfermidades infantis muito freqüentes (infecções das vias respiratórias superiores, diarréia), sendo por esta razão denominados sinais inespecíficos. Já os demais (dificuldade para respirar, cansaço, falta de ar, tosse e ruídos 
pulmonares) são característicos dos agravos respiratórios de trato inferior, mas nem sempre cursam com pneumonia.

Tal consideração é relevante e aponta para o fato das mães não terem mencionado sinais mais sugestivos de pneumonia, cujo conhecimento seria de grande valia para indicar a necessidade de buscar atenção para o filho em serviço de saúde.

Conforme foi exposto na parte introdutória do presente trabalho, a estratégia AIDPI recomenda a utilização de dois sinais clínicos, a freqüência respiratória aumentada e a tiragem subcostal, para a classificação de pneumonia em crianças de dois meses a cinco anos de idade exclusive. A escolha destes sinais se deu com base na constatação de seu alto valor preditivo para pneumonia a partir de várias investigações (Benguigui 1998).

Examinando atentamente os depoimentos maternos, nenhuma das mães referiu sequer um dos sinais recomendados pela estratégia AIDPI, detendo-se à menção de sinais mais gerais de adoecimento infantil e de outros relacionados a agravos respiratórios de trato inferior, mas não específicos para pneumonia.

Nesse sentido, cabe assinalar que a identificação por parte dos responsáveis dos sinais indicativos de pneumonia na criança é de importância fundamental. O reconhecimento desses sinais se constitui um alarme do problema e aponta para a necessidade de adoção de condutas visando sua resolução. Melhor dizendo, para que possam proporcionar tratamento adequado à criança, é condição necessária e indispensável que os pais saibam reconhecer os sinais clínicos de pneumonia e, tão logo eles surjam, estejam motivados para a busca de atenção em serviço de saúde.

Ainda que apenas o acesso aos serviços não ofereça garantia de melhores condições de saúde à população, a investigação conduzida por Chiesa e Bertolozzi (1997) revelou que a não percepção dos sinais, entre outros fatores, pode resultar em demora na procura de atenção em serviço 
ou mesmo em não procura e, consequentemente, em maior probabilidade de agravamento dos casos, restringindo assim as possibilidades de tratamento e recuperação das crianças e explicando em parte os óbitos infantis por esta causa.

\subsubsection{Causas da pneumonia}

No discurso das mães, emergiu uma série de fatores associados à ocorrência de infecções respiratórias em geral e, em particular, de pneumonia em crianças. De forma geral, constatou-se que as mães não fazem distinção entre os fatores que têm uma relação direta de causa-efeito na produção do agravo (agente causal ou etiológico) e aqueles que de alguma forma favorecem ou contribuem, ainda que indiretamente, para o adoecimento (fatores pré-disponentes e desencadeantes). Essa diferenciação faz parte do esquema conceitual categórico adotado pela ciência médica, que não se encontra difundido e incorporado pelo saber popular.

Diante disso, optou-se por apresentar os dados no presente subtema designado genericamente como "causas da pneumonia".

Nos relatos, observou-se ainda não haver indicios de qualquer compreensão quanto ao mecanismo de ação dos fatores causais na produção da doença. Tal lacuna no conhecimento não provoca surpresa. No entanto, sua existência pode explicar algumas das práticas de cuidado à criança doente adotadas pela população.

Ocupando o primeiro lugar em termos de freqüência nas falas, surge o frio ou a friagem enquanto agente responsável pelas doenças respiratórias em crianças, entre elas a rinofaringite e a bronquite, além da própria 
pneumonia. A exposição do organismo ao frio pode se dar de diversas formas, como através de baixas temperaturas, mudanças climáticas, ambiente refrigerado, ingestão de alimentos gelados, estar descalço e desagasalhado, tomar banho prolongado e realizar brincadeira com água, entre outras.

"Agora assim, a causa, causa assim eu só entendo que é por causa da friagem."(E1)

"Eu acho que o tempo, a mudança muito brusca. Que meu filho é só mudar o tempo, que começa o narizinho. "(E3)

"Friagem, gelado, eu acredito que isso."(E5)

"É, eu acho que por exemplo o frio né, a friagem né. Eu acho que é a frieza né, eu acho que é isso." (E6)

"Eu acho que é friagem. (....) Friagem, friagem, chuva, ficar descalço né $D .$, andar pelada no frio." (E7)

"Só deixar desprotegida assim no frio. Quando estiver frio, não deixar a criança desagasalhada." (E9)

"Acho que o frio né. (...) Eu acho que a mudança de tempo muito brusca né, deixar a criança desagasalhada assim, em baixo no vento. Eles estão quente dentro de casa e sair no vento. Eu acho que isso facilita. "(E11)

"Ah, acho que por causa do tempo. O frio, de repente vem o calorzão. Que nem esses dias agora estava esse calor, de repente vem aquela chuva, aquele vento de tarde. Eu acho que isso pode causar a pneumonia." (E12)

"Porque é muito mais fácil você sair tipo de noite, você tem que sair assim e a criança pegar um tipo de vento. "(E13)

"Se ficar tomando muito vento também dá. E se ficar tipo em água fria também dá"(E13) 
"Eu acho que é por causa da friagem e mudança de tempo. Bom, às vezes o tempo está quente, de repente vem aquela chuva. Aí, o tempo está muito quente, conforme dá aquela chuva de repente, você vê sobe tipo aquela fumaça do chão. Acho que aquilo ali é que causa mais a pneumonia."(E14)

"É os pés no chão, brincar com água, tomar bastante coisa gelada, pode aumentar (a chance da criança contrair pneumonia). "(E14)

"Acho que friagem, dar coisa gelada para criança dá pneumonia, deixar brincar com água, andar descalço." (E15)

" $\dot{E}$ que, em casa, eu estou acostumada a nada tomar gelado, e nem eu posso tomar muito gelado, porque se tomo... Está calor, tomo um gelado, já fico ruim. Não dar gelado para ela, eu não dou. Nem eu posso, se eu tiver com um sorvete com calor, eu fico ruim, no outro dia eu estou resfriada. Porque o tempo... Eu não posso tomar gelado. Se eu tomar gelado, eu estou ruim no outro dia. Então eu evito o gelado, porque toda vez que eu tomo gelado fico resfriada, fico ruim. Acho que é o tempo também né. Está assim, está ruim... Só eu tomar um sorvete, que eu posso tomar quando está meio frio. Aí quando está muito calor, eu não posso nem pensar em sorvete. No outro dia, o resfriado volta, 5 ou 6 vezes, volta. Meu corpo não agüenta. "(E18)

"Porque dizem que pega pneumonia com chuva, não sei o quê, e gelado, coisa gelada, e eu sempre estou tomando cuidado. (...) Sei lá, será que é assim mudança de tempo, gelado. Eu acho que coisa gelada também."(E19)

“Quando está frio o tempo né, eu percebo que é rapidinho para ela ficar resfriada. E do que ela começa a tossir, pronto. (....) Quando está frio, que ela fica assim, é rapidinho para ela ficar, sabe, resfriada. E eu ali: "calça o chinelo", ponho gorro. Mas é mais quando está tempo frio." (E20) 
"Ela tinha oito meses, nós estávamos lá em Rondônia. Você sabe que lá é um calor insuportável né. Então, ela era bebezinha ainda né, acho que ela tinha uns cinco meses. Quando veio de lá, nós entramos dentro do ar condicionado, dentro do ônibus. Foi aí a primeira vez que ela ficou doente né. Então, acho que saiu da quentura e foi para o frio."(E20)

Depreende-se das falas que o organismo humano saudável, dotado de uma certa temperatura estável, tende a se desequilibrar mediante contato com uma fonte de frio ou de calor, tornando-se doente. O desequilibrio e, consequentemente, a doença respiratória é mais comumente provocada pelo contraste de temperatura entre o corpo, que tende a quente, e algo frio, mas poderiam também ser ocasionados pela exposição ao calor intenso.

Esta concepção tem suas raízes no pensamento hipocrático, que remonta ao período da Grécia antiga (século $V$ a.C.). Em diversos documentos sobre a história da medicina ocidental e a evolução do conceito de doença até os dias de hoje (Oliveira 1981; Mossé 1985; Tamayo 1988 e Moura 1989), a teoria humoral da doença, formulada por Hipócrates (460 a 377 a.C.), recebe atenção especial, dado que dominou o pensamento médico europeu por séculos e, ainda hoje, alguns de seus elementos estão incorporados no pensamento contemporâneo de enfermidade.

A teoria humoral da doença tem dois postulados básicos. O primeiro postulado é que o corpo humano contém quatro humores ou líquidos diferentes, que guardam uma correspondência com os elementos básicos que constituem a Natureza: o sangue (Ar), a fleuma (Água), a bile amarela (Fogo) e a bile negra (Terra). A composição essencial de cada um é diferente, possuindo propriedades especiais, podendo ser quente, frio, úmido, seco, doce, ou amargo. Essas características variam de acordo com a época do ano.

O segundo postulado é que a saúde advém do equilíbrio dos humores, isto é, a igualdade ou harmonia de todas funções (úmido-seco, 
frio-quente, amargo-doce etc.), enquanto que a doença é resultado do predomínio de uma qualidade sobre a outra, qualquer que seja o membro do par que domine. O equilíbrio qualitativo, e não meramente quantitativo, entre as propriedades dos humores é indispensável para a manutenção da saúde.

Segundo esta teoria, a doença se deve a uma causa interna como a alimentação, através da ingestão excessiva de alimentos quentes ou frios, ou externa, ligada ao clima por exemplo. Greco (apud Campos 1982) acrescenta que, obedecendo aos mesmos principios, as doenças são classificadas em frias ou quentes, sendo as enfermidades respiratórias percebidas como frias, vindas de fora para dentro do corpo.

A cura é vista como regresso ao equilíbrio, possibilitada através da introdução gradual do princípio oposto ao da causa da doença no corpo. Acreditava-se no potencial natural do organismo para a cura, cabendo ao médico apenas ajudar a restabelecer o equilibrio dos humores no corpo, em geral através de três tipos de tratamento: sangria, purga e dieta alimentar.

Assim, pode-se verificar que os relatos maternos estão plenos de elementos constitutivos da teoria hipocrática, ainda que por vezes apresentados com outra roupagem. No que toca às causas da pneumonia, sua atribuição ao frio é um exemplo claro disso.

Cabe destacar que tem origem no pensamento hipocrático também o sistema de categorias empregado pelas mães para construir seus discursos, que corresponde às propriedades mais universais das coisas, como benigno ou grave, fraco ou forte, leve ou pesado, frio ou quente, seco ou úmido. As representações são elaboradas não a partir de um princípio geral, mas através de um raciocínio que funciona com oposições binárias simples.

Não resta dúvida de que os próprios profissionais de saúde contribuíram e ainda contribuem para a difusão e incorporação desses elementos no saber popular, uma vez que o pensamento científico se pautou 
nesta base conceitual até muito recentemente, encontrando-se dessa forma difundido no pensamento coletivo.

Essa crença ainda persiste com todo vigor nos dias de hoje, não tendo sido suplantada com a descoberta do papel dos agentes microbianos na causação da doença, nem com investigações científicas realizadas a partir da metade do século passado demonstrando que o frio não é responsável direto pelas infecções respiratórias. Talvez isso se deva em parte à maior freqüência de doenças respiratórias nos meses frios, que se justifica por uma série de contingências presentes nesta época do ano, tais como maior aglomeração e contato fisico entre as pessoas, favorecendo o contágio (Díaz 1998).

No corrente ano, em matérias divulgadas em veículos de ampla circulação na cidade de São Paulo, foi dado grande destaque ao tema, buscando-se esclarecer a comunidade leiga acerca deste e outros mitos relacionados às infecções respiratórias (Varella D 2002; Varella F 2002). É possivel que repercussões da difusão destas informações sejam observadas no pensamento coletivo futuramente.

Retomando a apresentação da análise dos discursos maternos, considera-se a seguinte cadeia de eventos no sentido de explicar a origem do agravo em pauta: a criança, uma vez exposta ao frio, está sujeita a adoecer e desenvolver um resfriado que, por sua vez, pode se agravar tornando-se uma pneumonia. Assim sendo, a pneumonia é tomada como resultado da progressão ou má evolução de um resfriado, doença considerada leve, constituindo-se uma complicação dele.

"A friagem que faz isso. (...) Depende da temperatura. Assim como está hoje, está muito frio, ela (criança) pode pegar um resfriado. Ai, pode fazendo tipo um dos mais grave né, uma pneumonia ou uma bronquite forte né."(E1) 
"Talvez por um resfriado muito prolongado, acho que pode ocasionar também pneumonia. "(E3)

"E a pneumonia, ela vem do resfriado e daí não trata. Eu acho. Pode ser uma pneumonia, pode virar uma pneumonia. Eu acho assim. Eu não sei se é verdade, mas eu acho isso. Porque se ela é uma secreção que junta no pulmão, então... "(E8)

"Agasalhar bem e ter bastante cuidado para que não deixar ela pegar frieza, não pegar resfriado. Que a pneumonia é causada através de um resfriado e a criança não está bem agasalhada."(E9)

"Que é um resfriado que fica mais forte né e pode dar tosse, pode né."(E11)

"Eu acho assim que pega de resfriado né, coisa assim. É resfriado né. É só isso que eu sei. Eu não sei muito não."(E20)

A compreensão da enfermidade enquanto uma complicação ou evento secundário às infecções das vias aéreas superiores corresponde a aquilo que comumente se observa nos casos de pneumonia aguda contraídos na comunidade. Além disso, tal percepção pode estar sendo reforçada pelos profissionais nos atendimentos pediátricos prestados nos serviços de saúde.

O processo de adoecimento é atribuído à falha da mãe no que se refere ao cuidado da criança. Entende-se que o mau desempenho das funções maternas envolve tanto a exposição da criança aos fatores que levam ao seu adoecimento (basicamente o frio), quanto a omissão na adoção de condutas que promovem a saúde infantil e ambas as situações, conjuntamente ou não, acabam por resultar no episódio de pneumonia. Nesse sentido, o cuidado infantil insuficiente ou inadequado é trazido como um fator crucial para explicar a ocorrência de pneumonia. 
"Agora se são aquelas mãe desleixada, as crianças fica doente rapidinho." (E1)

“A pneumonia em si? Para mim é uma gripe bem forte, bem forte. Acho que para mim é falta de cuidado, que é uma gripe que mal cuidada, que pode se tornar uma pneumonia. Bom, a criança estando com sintomas de gripe: febre, essas coisas, se você não for no médico e não procurar saber, pode agravar a situação e pode se tornar uma pneumonia. No meu ponto de vista é isso. "(E4)

"O contrário dos cuidados né, que é dar gelado, é sair na friagem, tomar chuva, essas coisas. Quando está calor, quando não está com nada, a gente extrapola né. Mas quando está com um pouquinho de gripe, a gente já toma cuidado para evitar a piora. "(E4)

"É, vamos supor, é uma tosse, alguma coisa com catarro, que não é bem cuidado. Eu acho que é assim né. E não está cuidado bem, aí vira, eu acho que vira pneumonia né."(E7)

"Falta de cuidado da mãe né. Deixar a criança desagasalhada, andar descalça, pegar chuva."(E11)

"Se ele pegar um resfriado e você não souber cuidar, também. Acho que se não tratar direito né. Se você não tratar e ele voltar de novo, volta pior." (E15)

"Eu acho que, na minha opinião, pneumonia vem através do resfriado. $A$ mãe não cuida né, deixa passar dois, três dias, aquele resfriado forte... Ai, acaba virando pneumonia né. "(E16)

"Ah, eu acho assim que as crianças que a mãe não cuida bem, deixa mais no tempo frio, deixa mais brincar com água, acho que isso aí causa a tosse, essa doença. "(E17)

"A falta de cuidado. A mãe deixar com o pé no chão, no gelado, não cuidar da criança direito né. "(E18) 
Assim, a criança doente é vista como aquela cuja mãe não está preocupada com seu bem-estar e, por isso, negligencia seu cuidado. Tem-se a impressão de que o comportamento materno é considerado como um ato deliberado com o propósito de prejudicar o filho, pois o contexto de vida em que o mesmo se dá e que poderia explicá-lo não é levado em conta. Essa noção de causalidade acaba por responsabilizar única e exclusivamente a mãe (ou seria culpabilizá-la?) pela situação de saúde do filho.

Nas falas acima, evidencia-se uma completa descontextualização e desvinculação da conduta materna das condições de vida e trabalho da familia, tais como condições de moradia, renda, escolarização, ocupação. Tal fato sugere que não há percepção quanto à determinação social na gênese do processo saúde-doença e das possibilidades (ou limitações) para o enfrentamento dos problemas. Tanto as causas da pneumonia quanto as intervenções (práticas de cuidado) estão colocadas no âmbito individual.

Muito embora recentemente tenham ocorrido grandes transformaçōes na vida das mulheres, merecendo destaque sua inserção no mercado de trabalho e maior acesso à educação e informação, a maternidade continua sendo o componente central na definição da identidade feminina em nossa sociedade. Conforme Brioschi e Trigo (1989), elas "não se sentiriam legítimas diante de si e dos outros" sem a maternidade.

Essa concepção está alicerçada no ideal de mãe desenhado em conformidade aos interesses econômicos, políticos e sociais dominantes a partir do século XVIII, o qual persiste de certa forma até os dias de hoje. Pautada nos dogmas rousseaunianos de então, a mulher é representada como um ser dotado pela natureza de atributos naturais e essenciais para ser mãe. Deste modo, vincula-se a mulher à função de mãe de forma inevitável (Badinter 1985).

Por ocasião da formação do Estado moderno brasileiro, as mulheres foram chamadas a assumir importante papel. Segundo Costa (1983) e 
Nunes (1991), no século XIX o Estado moderno, voltado para o desenvolvimento industrial urbano, necessitava de um controle demográfico e político da população adequado àquela finalidade. Nesse contexto, a medicina, através do movimento higienista, desempenhou um papel fundamental na reorganização das famílias em torno da conservação e educação das crianças, estimulando desse modo a política populacionista.

Os higenistas definiram as novas normas de organização e convivência dentro da família, bem como os novos papéis e funções para seus membros. Nessa nova ordem social, coube à mulher o cuidado dos filhos, de forma a suprir uma nação carente com uma população forte e produtiva (Zioni e Adorno 1990).

As mães participantes da presente investigação, sujeitas às influências da concepção de maternidade existente no pensamento coletivo e em parte moldadas por ela, tomam para si a responsabilidade do cuidado infantil, entendendo-o como fruto do desejo ou instinto maternal e desvinculado de suas condições materiais de vida e do contexto estrutural mais amplo.

Outros fatores foram aventados como responsáveis pela pneumonia, apesar de terem tido mínima expressão nos discursos maternos. A etiologia infecciosa foi referida por duas mães (E8 e E13), sendo apontados dois aspectos: a possibilidade de contágio através de contato com um indivíduo doente e a especificidade do patógeno causador da pneumonia, por analogia à experiência pregressa, vivida com o filho, na vigência de um episódio de meningite.

"Ela (vizinha que trabalha em creche) falou 'você tem que dar o remédio na hora certa para matar a bactéria, porque senão ela pode voltar'. Os médicos falam que (pneumonia) é (causada por uma bactéria). Eu imagino né, ela (bactéria) é um bichinho bem pequenininho. (....) Então, eu imagino que ele seja um bichinho. Eu creio que não sendo o mesmo 
bichinho (que causa a meningite), mas eu creio que deve ser um bichinho né." (E8)

"Se as pessoa tiver (pneumonia), pode pegar. Não? Pode? Ah, sei lá. Se começar espirrar, eu acho que pode."(E13)

É surpreendente que o agente microbiano não tenha sido mencionado como causador da pneumonia por um número maior de mães, uma vez que seu papel na causação da doença é documentado de longa data. Em relação a isso, cabe apontar que várias mães citaram o emprego de antibióticos no tratamento da patologia, embora não tenham assinalado se tratar de moléstia de caráter infeccioso. Parecem não ter conhecimento do significado do termo antibiótico e, portanto, não o associam à existência de um microrganismo na determinação da doença.

Foram relatadas também causas que se referem ao ambiente domiciliar da criança, mais especificamente relacionadas à qualidade do ar. Três mulheres (E10, E13 e E14) fizeram menção ao pó ou poeira existente no interior da casa e outra (E18) se referiu ao fumo.

"Se eu não me confundo, acho que a poeira. Pode ser o pó."(E10)

"Não sei porque, mas sempre perguntam se tem cortina ou tapete em casa. Porque eu acho que por causa do pó, porque tem pessoas que podem ser alérgicas no caso. "(E13)

“É poeira."(E14)

"Eu estou achando que é o cigarro, não é? Porque ele (companheiro da mãe) fuma demais."(E18)

No caso do fumo, cabe esclarecer que houve associação entre o ato de fumar e a ocorrência da doença, não havendo referência ao prejuízo à saúde que a fumaça do cigarro causa às pessoas que a inalam, na qualidade de fumantes passivos. Sabe-se que por ocasião da pesquisa, o companheiro da mãe era um fumante contumaz que se encontrava 
acometido por pneumonia e acredita-se que a associação do fumo à enfermidade teria vindo dai.

Em duas entrevistas (E1 e E3), a baixa idade foi pontuada como um fator que torna o indivíduo mais vulnerável à pneumonia, sendo elencados dois motivos. Salientou-se a imaturidade imunológica, entendida como característica dessa faixa etária muito jovem, e a dependência relativa ao cuidado imposta pela condição infantil.

“... porque (as crianças) são muito novinho, então eles são mais fácil de pegar." (E1)

“...porque eles são ainda muito pequenininho e não sabem fazer nada ainda por eles né. Então, a gente tem que fazer por eles e por nós também né. Porque ai quando eles estiverem grande, aí eles vão saber." (E1)

“A criança sempre está propicio a isso (pneumonia). Mas mesmo as que ficam em casa todo dia, acho que elas são mais doentes das que saem né. Acho que elas não pegam imunidade. Ah, não sei."(E3)

A pneumonia foi atribuída ainda à alimentação insatisfatória e à ocorrência de problema relacionado ao parto.

"Acho que a falta de alimentação muito boa assim também prejudica."(E11)

“Uma já nasce com problema respiratório. (....) Acho que por causa que a água (líquido amniótico) deve ter ficado sem coisa para respirar lá dentro por causa da bolsa d'água, ou então se demorar a nascer também."(E13)

O conjunto de fatores causais lembrados pelas mães incorpora, ainda que de forma distorcida, fragmentos extraídos da ciência médica, que no processo de assimilação pelos individuos sofreram reinterpretações. Ao serem incorporados pelo saber popular, estes conhecimentos são 
descontextualizados e passam a carregar novo sentido, uma vez que são apoiados numa rede de significados pré-existente.

Conforme foi exposto nos subtemas anteriores, a pneumonia é compreendida pelas mães a partir do enfoque biomédico, que a reduz a um mau funcionamento orgânico localizado nos pulmões, passivel de tratamento e cura, mas que pode levar a criança ao óbito caso esta não receba a devida atenção. Entre as manifestaçōes clínicas da pneumonia infantil, deu-se destaque à febre seguida pelos sinais: estado geral prejudicado, dificuldade para respirar, tosse e ruídos respiratórios.

Quanto à explicação sobre a origem da doença, prevaleceu a noção de que a pneumonia é causada pela exposição da criança a baixas temperaturas, em decorrência principalmente de negligência ou incompetência materna na realização de seu cuidado. À mãe, vista como a principal provedora dos cuidados infantis, é atribuida a responsabilidade pelo adoecimento ou agravamento do problema de saúde do filho, bem como pela promoção, manutenção e recuperação de sua saúde.

A abordagem biomédica reduz a doença a um fenômeno endógeno, localizado em uma parte do corpo do indivíduo, perdendo-se de vista o ser humano como um todo. A enfermidade é trazida como um mau funcionamento de uma das partes do corpo (os pulmões) em decorrência da ação de determinantes "naturais" (frio, pó, alimentação inadequada, microrganismo).

O problema da abordagem biomédica, assim como de outras igualmente estáticas, reside em estabelecer uma dicotomia entre o fato individual e o fato social, ambos tomados como puros e estanques. De acordo com Velho (1985), a doença deve ser vista enquanto fenômeno biológico, psicológico e sócio-cultural, em seu caráter de inter-relacioamento complexo e permanente. 
Conforme Minayo (1992, p.181), essa concepção médica de saúde/doença se "atém ao contorno biológico e individual do doente. Desta forma, explica o fenômeno saúde/doença como o bom funcionamento dos órgãos e como responsabilidade individual. Separa o sujeito de seu meio, de sua experiência existencial, de sua classe e dos condicionamentos de sua situação. Em segundo lugar, transforma o conceito de doença numa especialidade a respeito de determinado órgão, considerado o corpo do doente como objeto de saber e espaço de doença."

A ciência médica limita-se à compreensão dos mecanismos biológicos envolvidos numa lesão em alguma parte do corpo. Entretanto, esses mecanismos, em geral, não se constituem as causas exclusivas de uma doença. Conseqüentemente, a prática baseada em tão reduzida abordagem não é eficaz na promoção e manutenção da saúde e só se modificará quando outros aspectos, como psicológicos, sociais e ecológicos forem incorporados à teoria e prática médica (Capra, 19882). Ampliada a base conceitual de saúde e doença, outros setores sociais e econômicos da sociedade deverão atuar na melhoria da qualidade de vida da população, articulados e coordenados com a saúde.

Essa concepção reducionista é ainda hegemônica nos dias de hoje, mas muito lentamente vai cedendo lugar à uma concepção mais abrangente, um novo conceito onde saúde é concebida como uma prática cotidiana de vida. Dentro dessa nova concepção, as ações de saúde não devem ficar restritas à oferta de serviços médico-hospitalares à população, mas devem contemplar, sobretudo, a atuação intersetorial a nível dos determinantes de saúde (Vilela, 1996).

Os conhecimentos maternos denotaram uma compreensão sobre o tema algo limitada, confusa e vaga. Trata-se de um conhecimento essencialmente prático baseado principalmente nas experiências com a doença vividas pessoalmente ou observadas entre os membros da família e da vizinhança, e nos discursos médicos. Observou-se a convivência de 
elementos modificados oriundos da ciência, ao lado de outros provenientes dos diferentes campos do saber social como as tradições e crenças populares.

As mães cujos filhos já adoeceram por pneumonia mostraram algum diferencial em termos de conhecimentos, porém restrito a certas características observáveis. Contudo, essas experiências não permitiram uma compreensão qualitativamente diferente. Constatou-se que as concepções relativas à doença permaneceram ao nivel do senso comum, persistindo muitas distorções e lacunas de conhecimento que restringem sobremaneira a compreensão acerca do tema.

Buscando compreender as concepções maternas acerca da pneumonia, é necessário considerar os processos de ancoragem e objetivação envolvidos na construção das representações sociais. Assim sendo, julgou-se necessário discorrer sobre isto a fim de elucidar algumas questões identificadas no discurso das mães.

O significado que os fenômenos têm para as pessoas possui um duplo aspecto. Por um lado, os fatos se apresentam ao indivíduo carregados de noções, idéias e concepções que foram elaboradas pela sociedade. Tais conteúdos são transmitidos e assimilados pelos sujeitos ao longo da vida nos processos de socialização primária e secundária, bem como através dos veículos de comunicação.

Por outro lado, esse significado é particular para cada um, assentado na rede de significados (pré-)existente na pessoa. A realidade é apreendida de modo único pelos diferentes indivíduos, que a assimilam conferindo-lhe um sentido próprio a partir das conexões que são estabelecidas entre o fato, a experiência ou o conhecimento novo que está sendo incorporado e o ideário pertencente à malha de significados da pessoa.

Nesse sentido, o fato em si é depositário de conceitos construídos coletivamente e, ao ser captado, é dotado de um significado particular a 
cada um. A realidade, ao ser internalizada pelos sujeitos, assume um sentido pessoal e único, embora este significado seja sempre mediado pelo social.

No universo representacional materno, encontram-se alguns elementos modificados provenientes da ciência, ao lado de outros oriundos de diferentes campos de saber social, tais como o saber popular e as tradições. Emergem noções vagas e deformadas se confrontadas com o saber acadêmico disponível. Ocorre que o conhecimento científico sofre transformações ao ser introjetado pelas mães. Ao lado da ciência, vão sendo apreendidos elementos de outros campos do saber social, sendo articulados uns aos outros e atrelados à rede de significados pré-existente na pessoa. Assim, constitui-se o universo representacional materno.

O objeto novo representado se integra ao repertório do indivíduo. No processo de construção das representaçōes, novos conteúdos figurativos e conceituais são atribuídos ao objeto, uma vez que ele é comparado ao que lá já está e também é classificado com base na convergência/divergência em relação aos aspectos que o definem. As representações são uma reinterpretação dos fatos ou fenômenos apreendidos, pois como diz Moscovici (apud Sá 1993) "representar uma coisa (....) não é com efeito simplesmente duplicá-la, repetí-la ou reproduzí-la; é reconstituí-la, retocá-la, modificar-lhe o texto".

Outro aspecto importante a assinalar diz respeito ao nivel de escolaridade materno. Recapitulando, o grau de escolarização das mães se mostrou baixo, com apenas três delas tendo completado o ensino médio e oito o ensino fundamental, encontrando-se todas as demais (9) aquém disso. O grupo de mães cujos filhos já sofreram episódio de pneumonia previamente revelou uma situação escolar particularmente ruim. Das seis, cinco apresentavam de quatro a sete anos de estudo e apenas uma tinha I Grau completo. 
Examinando os discursos detidamente, entende-se que o nivel de instrução das mães pode ter se constituído fator relevante na construção do seu conhecimento. Sendo a escolaridade no âmbito geral bastante baixa (apenas três mães com nível médio e nenhuma com nível superior), a compreensão materna acerca da pneumonia foi bastante assemelhada no seu conjunto. Nos dois niveis de ensino, primário e secundário, 0 entendimento foi limitado, mostrando-se vago, desarticulado e não muito seguro.

Supõe-se que a educação materna modifique as crenças $e$ conhecimentos sobre as doenças e seu tratamento e melhore as práticas de cuidado infantil no domicilio. Contudo, há dificuldade de saber em que medida a relação entre educação e conhecimento é apenas reflexo do impacto das condições sócio-econômicas associadas.

De acordo com Cleland e van Ginneken (1988), há pouquísimos estudos que oferecem dados a respeito do impacto da educação materna sobre os conhecimentos e práticas relativos a doenças (suas causas e seu tratamento) realizados em paises em desenvolvimento. Investigações recentes concluem que a escolarização primária pode ter um pequeno efeito sobre os conhecimentos e as crenças relacionadas a doenças, mas que ela pode significar grandes mudanças no comportamento materno quando ocorre adoecimento (van Ginneken et al. 1996).

Em pesquisa desenvolvida em Cuba, por Roque e Canalejo (1999), avaliou-se a influência da educação das mães de crianças menores de 5 anos sobre os conhecimentos, atitudes e práticas (CAP) das mesmas acerca das IRA. Foi encontrada forte associação entre a suficiência dos CAP relacionados às IRA e o nível educacional materno, embora não tenham sido controladas as variáveis sócio-econômicas. As mães de crianças hospitalizadas foram as que apresentaram menor indice de conhecimentos bem como atitudes e práticas menos acertadas, podendo estas últimas terem contribuído para o desfecho do problema. 
Analisando a relação e a comunicação entre médico e cliente, Boltanski (1989) oferece outros elementos para explicar a conformação o discurso materno. Assim, segundo este autor, quando o cliente pertence às classes populares, o médico não dá grandes explicações, porque entende que não falam a mesma linguagem, a língua das classes cultas, nem que 0 sujeito está em condições de compreender o que vai ser dito a ele devido a sua "ignorância". O profissional então, transmite informações parceladas e não realiza esforços para favorecer a comunicação entre eles.

As razões e os conhecimentos que fundamentam e dão sentido às recomendações médicas não são explicitados, nem mesmo quando são observadas resistências ou objeções a elas por parte do cliente. Nesse caso, são enumeradas as conseqüências da desobediência, que assumem o caráter de sanções. Exemplificando, é dito que se deve administrar o medicamento corretamente porque do contrário a criança pode até morrer, mas não se explica o princípio que embasa a conduta. Assim sendo, os conhecimentos maternos são insuficientes para sustentar uma prática efetiva de cuidados à criança.

$E$, finalmente, tendo as experiências sido ressaltadas como fonte de motivação e aprendizagem sobre o tema, poder-se-ia supor que a experiência de ter tido um filho acometido por pneumonia tivesse ampliado e aprofundado a compreensão das mães acerca do fenômeno. Contudo, observou-se que não implicou um conhecimento de teor diferenciado. Tal como as demais, as mães experientes expuseram um conhecimento restrito, vago e deformado se comparado ao saber científico.

Refletindo em maior profundidade sobre essa questão, o fato do conhecimento das mães se apresentar igualmente limitado, desarticulado e incerto para o grupo de mães experientes pode explicar em parte o adoecimento de seus filhos. As representações têm importância inegável à medida que as atitudes $e$ ações dos indivíduos são orientadas pelas concepções que têm acerca dos fenômenos. Assim sendo, este 
conhecimento prejudicado estaria de alguma forma, juntamente com outros fatores, comprometendo a conduta materna no que tocante ao cuidado dos filhos.

Não se quer com isto afirmar que a causa do adoecimento infantil está no (des)cuidado prestado à criança, mas sim que não tendo uma compreensão ampliada e aprofundada sobre o problema e as necessidades de saúde do filho, a mãe poderia estar inadvertidamente contribuindo para agravar seu estado, seja por realizar condutas impróprias no domicílio seja por retardar a busca de atendimento da criança em serviço.

Dado que no processo de construção das representações, o novo é introjetado e dotado de significado a partir das conexões que estabelece com a bagagem de conhecimentos pré-existente no indivíduo, a compreensão da pneumonia fica comprometida pelo grau de escolarização baixo. Nesse sentido, o discurso materno é bastante coerente com sua trajetória de vida e também com a situação saúde/doença de seus filhos. A inserção social desfavorável atua determinando tanto a ocorrência de doenças como as possibilidades de enfrentamento dos problemas. 


\subsubsection{Práticas de cuidado materno relacionadas à criança com pneumonia}

Nesta categoria são apresentados os cuidados relacionados à criança com pneumonia no domicilio, visando a prevenção e o tratamento da doença, além da promoção e manutenção da saúde infantil. Nela estão contidos os seguintes subtemas: "busca de atendimento à criança doente em serviço de saúde", "cuidados preventivos e de promoção à saúde da criança relacionados à pneumonia" e "cuidados à criança com pneumonia no domicilio".

Cumpre esclarecer que a pesquisadora não se deteve no detalhamento das práticas e sim nas propostas propriamente ditas, uma vez que o método de coleta de dados deste estudo (entrevista) não permite uma descrição completa e fidedigna do fazer materno. Neste sentido, aponta-se a necessidade de realização de outras investigações, a fim de levar a cabo tal tarefa.

A seguir, passa-se à exposição dos subtemas supracitados que compõem a categoria.

\subsubsection{Busca de atendimento à criança doente em serviço de saúde}

A procura de atenção à saúde da criança em serviços de saúde consiste em uma prática relevante por dela dependerem em grande parte 0 diagnóstico e o tratamento oportuno da pneumonia infantil. Por essa razão, na presente pesquisa foram investigados alguns aspectos importantes que caracterizam essa prática, quais sejam: o reconhecimento dos sinais indicativos de adoecimento infantil que motivam a busca de atenção, a 
escolha do serviço de saúde e as dificuldades encontradas para obtenção do atendimento.

As mães são muito atentas a seus filhos, especialmente ao surgimento de sinais e sintomas que indicam adoecimento da criança. Entende-se que esta preocupação se deva ao fato da criança ser percebida como um ser mais frágil e, conseqüentemente, mais vulnerável a doenças. Ademais, tal condição de fragilidade e susceptibilidade coloca a criança em situação de maior risco de ocorrência de problemas de saúde de maior gravidade.

"Bom, no meu caso assim, eu observo muito ela né. Quando ela está muito irritada, muito triste assim e eu fico olhando bastante, aí eu falo assim 'ah, eu vou levar você no médico para ver o que você tem', porque às vezes pode ser alguma coisa que vem dela assim, mas é bom levar né. Eu sou assim. Qualquer coisinha eu estou trazendo para ver se é alguma coisa grave ou não. Eu acho assim que a mãe tem que observar muito a criança, porque às vezes ela acha que ela não tem nada, mas na verdade ela tem né. Eu observo muito"(E1)

“Assim, quando ela está muito assim agitada, ela está agitada, ou então quando às vezes ela num quer assim, só quer ficar sabe chorando, chorando, sem fazer nada, aí eu trago ela para o Centro de Saúde para ver se ela tem alguma coisa, mas os médico fala que ela não tem nada. Mas sempre falo para ver, para ver com cuidado, para ver que não há nada grave. Eu, eu trago todo dia assim, se eu acho alguma coisa diferente nela, eu trago. Umas manchinhas assim. Por exemplo, umas manchinha que nem essa, eu trago. Assim, quando eu não sei se ela tem alguma cólica assim. Pode ser cólica às vezes, eu não sei o que é, eu trago. Porque nem sempre a gente sabe mesmo né. "(E1)

"Olha, eu sou tão preocupada com minha filha, até porque eu só tenho a S. . Então, eu procuro cuidar assim, dar o melhor que eu posso. Então, o minimo que acontece eu já venho ao médico para evitar um problema maior."(E5) 
"Eu vi ela muito mal, aí eu tive que procurar o médico para saber o que é que era. Febre, cansada. Ai a febre deve ser por alguma coisa, alguma infecção. "(E9)

Assim, a procura de atendimento especializado para a criança doente é mais precoce e mais freqüente.

"Aí, a gente não sabe o que é que é. Então, aí, a gente corre para os médico né, para ver. "(E1)

"Bom, a primeira coisa é levar no médico né."(E4)

"A princípio procurar o médico né. Ir ao médico e estar atento às orientações do médico. "(E5)

“Quando ela era bebezinha, o prontuário dela está assim ó, de tanto que eu vinha no posto, qualquer coisinha. Ai tem vez que o povo fala 'Ah, a menina não pode fazer nada que você já corre para o médico'. "(E7)

"Desde quando eles nasceram, eu sempre tive medo. Ela mesmo, ela de novinha, ela tinha bastante cólica, ela chorava muito, ela ficava inquieta, eu pegava ela e já corria para o HU. Os médico de lá até ria, porque sempre dizia que era cólica e que não precisava se preocupar né. Que era para fazer bastante massagem na barriguinha, ou então esquentar a fralda no ferro e pôr na barriga da criança. Mas mesmo assim, sempre que ela chorava eu estava no hospital, sempre e eu a mesma coisa dele." (E14)

"Qualquer coisa que ele (filho) está assim mais ou menos eu já levo."(E15)

A maioria das mães lista um conjunto de sinais e sintomas que, quando presentes na criança, motiva-as para a procura de atendimento em serviço de saúde. Dentre os sinais e sintomas clínicos referidos, a febre foi aquele citado com maior freqüência, tendo sido mencionado por mais da metade das mães (12). Trata-se do sintoma mais claro de doença para as mães. 
"Ai, uma das primeiras coisas é a febre, porque febre é sinal de infecção. Para mim, é sempre uma das coisas mais que chamam é a febre. Ou então quando a criança está caída. É, ela fica dormindo demais, essas coisas. Eu levo no médico. A febre não demonstra se ela está né. Então eu uso uma das duas coisas, eu levo. "(E4)

"Acho que febre alta né."(E6)

"Apesar que eu, com essa daí, ela não pode ter uma febre que eu já corro para o posto. Qualquer coisa, eu já estou no posto. É, ela está com febre, se está tossindo direto que dá até ânsia, eu já corro também." (E7)

"Febre, cansada. Ai a febre deve ser por alguma coisa, alguma infecção. "(E9)

"Febre. Sempre quando ela (filha) tem, eu levo. Quando ela tivesse com febre, no mesmo dia que ela desse febre, eu já levo. Eu não espero 2 dias ou 3. "(E9)

"Sempre quando ela está doente, a primeira coisa que dá o sinal nela é febre. Ai eu vou no posto. "(E17)

Não é surpreendente a febre figurar em primeiro lugar entre os sinais que motivam a procura de atenção à criança no serviço de saúde, pois é um dos sinais de adoecimento mais comuns na infância e, historicamente, vem sendo associado a problemas muito graves (Penna 1988). Em razão disso a febre desperta medo nas pessoas e, quando ocorre em uma criança, os pais reagem com grande apreensão.

Segundo Frederico Neto (2000), há a crença de que quanto maior for a febre mais grave é a doença, embora tal relação não se confirme na prática. O medo de que possa significar algo de muito grave chega muitas vezes a prejudicar a percepção em relação ao estado geral infantil, que na maioria das vezes é satisfatório. Cabe esclarecer que a maior parte dos quadros febris provém de doenças de fácil controle e que a febre deve funcionar mais como um sinal de alerta do que de gravidade de uma doença, independente de seu valor. 
$\mathrm{Na}$ seqüência, em termos de freqüência, foram lembrados diversos sinais indicativos de comprometimento respiratório, conforme foi possivel constatar nos relatos expostos acima e abaixo. Entre os sinais respiratórios referidos encontram-se: cansaço (6), tosse (4), ruídos respiratórios (3), secreção pulmonar (3), falta de ar (3), e cianose (2).

“Acho que febre. Febre, acho que sim. O peito cheio, carregado também. De catarro, né. Acho que só. Para o começo, para você chegar e levar ao médico para saber realmente o que que é, acho que seria esses sintomas." (E3)

"Acho que a febre, o cansaço na respiração também ajudaria. Ficar roxo, talvez. Criança quando tem problema de respiração fica bem roxinha né. Fica roxinho. É só, porque ele teve sopro né, ou ainda tem, eu não sei. Aí, os médico falou 'cuidado com a respiração, se ele ficar muito cansado e roxinho corre para o médico'. Eu acho que deve ser isso." (E3)

"Chiado. Chiado e febre né. Agora mesmo eu trouxe porque ela apresentou febre, chiado e está tossindo. Eu tenho medo de uma pneumonia. Então eu já trouxe para..."(E5)

"É falta de ar, porque eles não conseguem respirar bem né." (E8)

"Acredito que a falta de ar, o barulho (ruído respiratório) também conta, né. Doença grave né? No começo eu achava que ele tinha um problema, né. Então, eu passei ele pelo otorrino. Pelo barulho dele está roncando assim, fazer barulho assim na hora de respirar. Barulhinho nas costinha dele de roncar e acredito também quando a criança fica cansadinha. Tinha pensado que a criança fica cansada, isso facilita sabia."(E11)

"Acho que quando está com falta de respiração, quando faz assim não consegue mamar. Quando tosse fica vermelho, bem vermelho. Eu vejo bebezinho pequeno ficar vermelho."(E13) 
"A febre. A febre e ele cansado, tossindo né, muita tosse. E chiando, o peitinho dele chiando. Acho que no segundo dia já eu levei."(E19)

"No caso dela, ela ficou cansada né. Cansaço. Já teve assim vez que se der hoje à noite mesmo eu levo. É, no mesmo dia." (E2O)

$E$ ainda outros sinais foram enumerados como indicativos de adoecimento infantil, tais como: dor, vômito, inapetência, lesão de pele, problema de ouvido e mau hálito. Embora tenham sido referidos com freqüência mínima, constituíram-se motivo para as mães buscarem atendimento para o filho em serviço de saúde.

"Se eu observar febre ou mau hálito, ou se ela se queixar do ouvido, ou se mosquito picar e ficar as marcas que custam cicatrizar, tudo isso." (E5)

"Vômito, não? Acho que sim né. Dor no corpo né. Na minha opinião é isso né." (E6)

"Se eu visse que ele está mamando e está vomitando ou não consegue mamar, que é estranho porque ele come bem, aí sim. "(E13)

"Tem vez que quando ela não está comendo direito, é quando ela coça bastante o ouvido, que ela tem problema no ouvido. Então eu procuro o posto. Só justificando, quando ela tem bastante febre, quando o ouvido coça, ou quando ela não come quase nada. Ai eu vou no posto para ver se ela não tem alguma coisa." (E17)

"Ontem eu notei que ela está se coçando. Dá para notar pela fralda, que eu vou trocar e ela fica quieta. Eu troquei, apareceu aquelas bolinhas, eu falei: 'pronto, está com problema já'. Falei para o meu marido 'está com bolinha, é bom levar para o médico'. Está com bolinha, que eu de olhar assim já percebo. Quando está meia quente, fica meio quentinha. Só assim."(E18)

Além dos sinais já descritos anteriormente, diversas alterações de comportamento da criança foram apresentadas pelas mães como indícios de doença e, portanto, justificativas para levar o filho ao médico. Tais 
manifestações são por vezes muito sutis, como alteração do tom do choro, evidenciando atenção e sensibilidade da mãe em relação à criança. Entre os comportamentos citados estão: expressão de tristeza, desânimo, diminuição da atividade, choro freqüente e em tom diferente do habitual, "moleza", necessidade de sono aumentada e agitação ou irritação.

"A maioria é pelo choro que a gente sabe né. Pelo choro e pela carinha, acho. Fica mais agudo assim, sabe. $O$ dela é bem forte, mas tem dia que o choro dela está bem fraquinho, alguma coisa ela tem. É porque quando eles estão alegre, eu acho que é porque eles não têm nada assim. Pode ter, mas não está demonstrando ainda." (E1)

"Carinha de meio tristeza, num mostra alegria, sem graça. Não quer saber. Só vive chorando. Isso ai que eu estava falando. Ai febre também, tudo essas coisa aí. Fica só vive chorando. Aí, eu fico agoniada e levo ele para o hospital." (E2)

"Fica com o jeito assim, com a cara assim, com o olhar frio, meia assim, que tem vontade de falar mas não consegue né. Alguma coisa né, sentindo dor por dentro. Ah, porque a gente toca assim nele assim, $e$ chora e tudo. É porque sente dor. Mostra a carinha assim de tristeza, com carinha assim que num... é... como que fala? É uma carinha assim enjoada, que não quer saber. A gente toca assim dói, em tudo."(E2)

"Moleza, que dá moleza também."(E3)

"Eu acho que muda o comportamento do bebê né. Porque você conhece o bebê diariamente, sabe que ele é uma criança calminha, se naquele dia ela não ficar, é alguma coisa que o bebê tem né. O choro né, muda o choro. Às vezes não fica aquela criança alegre. Que nem ele é brincalhão né. A criança doente já é tristinha né. Ah, o choro é um choro de dorzinha. É, muda." (E10)

"Ai qualquer coisinha assim diferente... Eles estão brincando, mas se eu ver assim ele meio cansadinho, ou ele bem molinho, eu já estou vendo que está estranho, aí eu já vou já para o hospital, não espero muitos dias não. (no último episódio de pneumonia) Porque tipo assim, ele começou 
a ficar cansado, cansadinho, só chorava, não queria comer e os olhos dele bem murchinho. Ai eu já percebi que ele não estava bem. Aí eu peguei ele e já levei no hospital. "(E14)

"Ah, eles fica molinho, chora, ai fala que dói aqui, dói ali. Os olhos dele mesmo fica fundo. Ela já fica mole, ela só quer dormir e deitar. Aí eu já levo no hospital." (E14)

"Ah, se está quieta demais. Ela é espuleta, brinca, quando eu percebo, já trago (para o serviço de saúde). Ou a falta de apetite dela. "(E18)

De um modo geral, os sinais vistos como indicativos de gravidade do quadro de doença eram os mesmos, apenas assinalou-se a piora ou maior intensidade de sua manifestação, como por exemplo "febre terrivel", "febre alta", "bem roxinha", "muito agitada", "muito triste" e "muito mal".

Pela riqueza de informações oferecidas pelas mães, pode-se perceber que elas têm uma percepção aguçada em relação aos filhos, absolutamente necessária para a identificação da existência de problemas de saúde. Entretanto, fica também evidente que não há uma diferenciação entre os sinais, colocando-se praticamente todos em pé de igualdade quanto à sua importância enquanto indicativos de doenças que mereceriam uma avaliação profissional.

Analisando os resultados encontrados nesta pesquisa, nota-se que as mães não reconhecem os sinais indicativos de pneumonia preconizados pela estratégia AIDPI (freqüência respiratória aumentada e tiragem subcostal), muito embora elas identifiquem vários outros sinais de comprometimento respiratório como cansaço, tosse, ruídos respiratórios alterados, secreção pulmonar, entre outros. Daí subentende-se que, uma vez sensiveis aos sinais respiratórios, pode-se direcionar seu olhar para o reconhecimento daqueles de maior valor preditivo para pneumonia.

Cabe aqui acrescentar comentário relativo à trajetória de atendimento das crianças, cuja gravidade do quadro de pneumonia exigiu tratamento hospitalar (E2, E9, E14 e E20). Segundo depoimento das mães, a hospitalização se deu no momento do diagnóstico da enfermidade, antes 
que qualquer tratamento tivesse sido iniciado. Isto significa que o estado de saúde da criança já era grave quando foi levada para atendimento em serviço de saúde.

Resta a seguinte dúvida: caso as mães tivessem reconhecido os sinais indicativos de pneumonia numa fase inicial da doença e tivessem levado seus filhos para atendimento em serviço de saúde prontamente, o diagnóstico e tratamento oportuno e adequado não teriam evitado o agravamento do quadro $\mathrm{e}$, conseqüentemente, a hospitalização? Possivelmente sim, é o que se crê.

Assim sendo, é primordial que as mães saibam reconhecer os sinais clínicos indicativos de pneumonia e que estejam motivadas para a busca de atenção em serviço de saúde mediante o seu reconhecimento. Para tanto, os programas de educação na área da saúde devem enfatizar este conteúdo.

Entre o reconhecimento desses sinais de adoecimento e a busca efetiva de atendimento para a criança, as mães referiram prazos bastante variáveis, compreendendo um período de três dias.

Quando não sabiam o que se passava com a criança, isto é, não identificavam o problema de saúde ou não estavam aptas a lidar com o mesmo, as mães referiram a procura de atendimento no serviço em no máximo um dia. Da mesma forma isso ocorreu quando o estado de saúde infantil era considerado grave. Nesses casos em que a doença infantil é julgada grave ou é desconhecida, o recurso ao serviço de saúde é uma exigência imediata, pois o médico é o único habilitado a tratar da criança.

"Mostra carinha assim de tristeza, carinha assim enjoada, que não quer saber. A gente toca assim dói em tudo. Levaria (para ser atendido) no mesmo dia, no mesmo dia eu levava. Que deixar para o outro dia é ruim, é até capaz da criança morrer. Enjoado, assim, que está muito, muito enjoado assim, aí eu levo. Quando está pouco enjoado assim, eu não levo não. Dois dias, por aí. Dois dias ou três dias, sei lá, acho que é."(E2) 
"Assim que eu notasse que ele estava roxinho, eu sairia correndo. Imediatamente. "(E3)

"Eu acho que somente aceleração no peito não. $A$ dificuldade para respirar aí eu já procuraria, que aí já tenho mais medo. Eu acho que no mesmo dia, depende da situação né. Se eu estou vendo que está prejudicando, que ataque muito ela (filha), que pode agravar, ter algum problema, acho que na mesma hora. Se fosse chiado com alguma coisa acompanhando sim, levaria. Não somente o chiado. Ou então a aceleração. Não somente a aceleração, alguma coisa acompanhando. Aceleração junto com a falta de respiração mesmo. Ai você já se assusta e vai para o serviço né. Então, dependendo da gravidade no mesmo dia, na mesma hora. Se eu ver que ela está perdendo peso. Com certeza. Dificuldade para comer sempre tem né. Tipo assim, tem um dia que a gente não está legal, a gente não come. Mas se eu ver que está prejudicando ela, que ela está perdendo peso, aí correria." (E4)

"Aí eu já levo no hospital. Minha mãe fala que eu sou doida. Ah, porque ela fala que tudo meu é levar para o hospital. Eu não conheço bem. Eu sei que essas coisas é grave, eu vou ficar esperando em casa? Não, já levo logo para o hospital. Ah, eu já vi pessoas que não conseguiam respirar, falta de ar. Eu não sei. No mesmo segundo, já ficou diferente já, eu já corro para o hospital, não é nem cinco minutos. "(E14)

"Ah, eu, o mínimo que eu passo em casa com a minha filha doente é um dia. Um dia, por causa que eu morro de medo. Já levo no posto. Um dia, um dia. O mínimo que eu passo com a minha filha dentro de casa doente é um dia. Passou de um dia, eu não passo de um dia. Se eu vejo que ela está bem cansando hoje cedo, eu espero um pouquinho até mais tarde. Se eu ver que ela continua, eu vou no pronto-socorro, vou em algum lugar."(E17)

"Que nem minhas vizinha fala que eu sou boba, que qualquer coisa que a minha filha tem eu corro para o hospital. Mas eu falei para elas que é assim. A gente não sabe o que ela tem, porque se ela soubesse falar... 
Que nem ontem, a menina queimou de febre a noite inteira. Quando eu falei que eu vou para o posto, elas falaram: 'larga de ser boba, não deve ser nada'. Aí eu falei: 'deve ser alguma coisa sim, porque febre não dá à toa'. Eu acho que tem que a mãe cuidar, cuidar de seu filho e quando a criança sentir alguma coisa, mesmo que não seja muito importante, tem que ir no posto para saber que que ela tem."(E17)

De acordo com o trecho acima, supõe-se que as mães recorrem ao médico mais rapidamente quando se trata de doença em criança. Isto se deve ao fato delas não poderem contar com a colaboração da criança para avaliar o problema, o que gera insegurança e ansiedade, fazendo com que procurem atenção para compartilhar com o médico as responsabilidades do cuidado infantil.

Havendo familiaridade com os sinais alterados e certo domínio em relação às ações de cuidado passiveis de serem realizadas no domicilio, as mães disseram iniciar o tratamento domiciliar prontamente. Diante dos problemas de saúde conhecidos e considerados benignos, as mães se percebem autorizadas e aptas a tratar sozinhas de seus filhos e põem em prática seus conhecimentos acumulados em experiências semelhantes anteriores. Dentre os problemas infantis tidos como tratáveis em casa encontram-se: tosse, secreção pulmonar, doença chiadora leve ou moderada, resfriado e doença febril não grave. Nestes casos, a procura do serviço de saúde ficou condicionada a não remissão dos sinais ou à piora do estado geral infantil.

"Assim, se eu tivesse observando tosse assim, levaria em dois ou três dias." (E1)

"Chiado. A principio, como eu já tive disso, que a minha filha tem problema de chiado, a primeira coisa que eu faço é pegar o inalador rapidinho e colocar umas 4 gotas de Berotec e $5 \mathrm{ml}$ de soro fisiológico. Eu faço essa medicação em casa porque eu tenho inalador. E é um costume também da minha mãe, que eu uso banha de galinha, passo no peitinho dela, esquento a banha de galinha. E depois eu procuro escutar, 
para ver se (o chiado) está ainda. E se eu ver que persistir, ai eu venho ao Centro de Saúde no máximo, para estourar, três dias. "(E5)

"(quando a criança apresenta febre) Primeiro eu dou dipirona ou tylenol. Dipirona, tylenol, novalgina. Segundo a orientação do centro de saúde, (criança deve ser levada para atendimento no serviço após) três dias. Eu não deixo esperar três dias. Eu venho antes, no segundo dia. "(E5)

“(mãe leva criança com tosse para atendimento em) Sempre três dias, sempre, porque também eu vou ver como que está minha filha. Eu vou ver se ela está jururu, se ela está igual você está vendo que ela está aí agora. Ou então eu faço isso: se de manhã se ela está normal, se a tarde ela não está normal, assim brincando normalmente. A minha filha é complicada, que às vezes ela está com 39 de febre, ela está correndo, está pulando. Então só eu mesmo para saber que ela está com febre. Não muda. Agora se tiver garganta, ela já fica tristinha, quase não fala. Você vê que ela é bastante falante, ela quase não fala. Então aí eu já sei, eu já corro logo. Hoje ela está bem. Hoje ela está bem porque ela está brincando, ela já falou bastante. Já viu todos os brinquedo, já fez a bagunça total né, já brincou bastante. "(E5)

"Quando eles estão resfriado que eu vejo que está com catarro no peito, eu dou esse xarope (caseiro) né e dou inalação. Aí eu nem levo no médico, quando é assim. Eu trato em casa mesmo. Agora, quando aparece febre, está com muita falta de ar, dai eu levo no médico, porque eu quero saber aí para ver se pode usar Berotec né. Porque o Berotec é um remédio muito forte, então a gente tem que usar passado pelos médicos. Embora eu já tenha ele em casa, mas eu tenho medo. Mas o remédio caseiro eu sempre faço." (E8)

"Se tipo você der inalação ou coisa assim, se você tiver o aparelhinho em casa, ou se não faz o que tiver. Se não der resultado, continuar tossindo muito, falta de ar, ai tem que levar. "(E13)

"Quando ele começa a chiar, o meu outro menino, ele chia mais. Ai eu começo a dar inalação em casa. Eu mesmo que faço e dou. Se eu já 
tenho o remédio em casa, se eu sei o que é que ele tem já, eu já dou. Acho que depois de dois dias, um dia, dois dias já está bom para mim levar. Se eu der inalação, qualquer coisa e não melhorar, eu já levo. Principalmente se apresentar febre né. Ai eu já levo. Ele tem febre hoje, amanhã eu já levo. Morro de medo de febre. Ah, se ele tiver só cansaço, sem febre, ai eu tento tratar em casa né. Se não conseguir, eu levo. Acho que dois dias está bom já. Se eu der inalação e não resolver, então eu já levo. Bom, a tosse eu tento tratar em casa, com esses melados aí mesmo. Ou às vezes eu compro remédio de farmácia, mas é dificil eu comprar um xarope, alguma coisa. Mas se eu ver que ele já está começando catarro ficar 'dentro do osso', aí eu já levo também. Acho que uns três dias. Só tosse assim só se tiver muito forte. "(E19)

"Ela fica muito assim mole assim, fica com febre. Dá febre né, e ela fica só querendo dormir, aquela moleza. E aí tossindo né. Sempre tem resfriado no meio né, tosse... Mas a que leva mesmo eu levar (ao serviço de saúde) mesmo assim é a febre. É, porque eu acho que quando tem febre é porque tem né infecção, tem alguma coisa. Aí eu levo, mas isso depois de uns três dias, assim." (E20)

Examinando os depoimentos acima reproduzidos, pode-se verificar que o tratamento dispensado à criança no domicilio é moldado pelas práticas médicas. Assim, embora o recurso ao serviço não tenha sido considerado necessário, o profissional permanece vivo no horizonte materno, definindo suas práticas.

Segundo Boltanski (1989), "longe de praticarem uma medicina paralela, as mães administram aos filhos remédios que o médico prescreveu anteriormente para tratar de doenças similares", melhor dizendo, as mães se espelham na conduta dos médicos, ou naquilo que elas podem apreender das práticas médicas, para prestarem o cuidado à criança em casa.

Atenta-se também para o fato de ter sido insistentemente citada pelas mães a espera de três dias para levar a criança ao serviço de saúde, após o reconhecimento dos sinais de doença. De acordo com o comentário materno 
de uma das mães (E5), a origem dessa prática estaria numa recomendação de um profissional do serviço.

Não se pode afirmar que os profissionais tenham feito tal recomendação às mães. Todavia, seja qual for a orientação profissional quanto aos critérios para procura de atendimento infantil em serviço de saúde, certamente este foi o entendimento de algumas mães.

$\dot{E}$ indubitável que este entendimento seja problemático, pois o retardamento do diagnóstico e, portanto, do início do tratamento da criança doente pode implicar no agravamento do quadro e/ou no surgimento de complicações. Quando se trata de um problema de saúde de evolução rápida, a procura tardia de atenção poderia comprometer as possibilidades de recuperação da criança, até mesmo resultando em sua morte.

É sabido que os serviços têm limitações quanto à sua capacidade de atendimento. É certo também, que a grande maioria das doenças infantis cursa com febre e que, muitas vezes, a avaliação do profissional não encontrará causa que justifique intervenção clínica. Entretanto a ida dos familiares ao serviço mediante reconhecimento de sinais de doença infantil deve ser estimulada e elogiada.

Estudos mostram que uma pneumonia não tratada pode matar em um curto intervalo de tempo, de 3 a 5 dias, e que uma grande proporção de mães de crianças que morreram não tinham se apercebido que os filhos estavam doentes, até que já se encontrassem em estado muito grave (Murray et al 1997).

Nesse sentido, deve-se rever com as familias os critérios de que se utilizam para decidir quando buscar atenção à criança, suprindo-as com informações efetivas, para que possam identificar quando a criança precisa de atenção. O problema está em centrar a decisão de levar a criança para atendimento num critério temporal e arbitrário.

Duas mães (E8 e E16) relataram experiências distintas das anteriores, nas quais o profissional médico se manifestou de forma contrária quanto ao uso do critério de tempo. Entretanto, pode-se perceber nas falas 
maternas que elas também tinham no seu horizonte representacional o tal critério temporal para busca do serviço.

Os depoimentos sugerem pensar ainda que nenhum outro critério veio substituir o primeiro, encontrando-se as mães sem parâmetros objetivos para avaliar a situação de saúde do filho e tomar decisão em relação à procura de atenção.

"Outra coisa, eu não gosto de deixar a criança ficar com febre dois, três dias. Se dar o medicamento e a febre voltar, eu levo. Porque quando a minha filha teve meningite, a médica falou para mim 'se você fosse esperar dois ou três dias, não ia dar tempo mais de socorro'. Porque ela teve febre oito horas no domingo, na madrugada teve vômito e quando foi sete horas da manhã ela começou a pele dela ficar manchada, dai eu levei. Não por causa da febre, mais por causa da mancha da pele. Ai constatou a meningite. Então, desse dia então, eu não espero mais. Então uma febre para mim se ela vai e volta... Vejo a garganta às vezes né. Quando eles tão grande tipo T., eu mando abrir a boca, dai eu vejo se é essa vermelhidão, alguma coisa. Mas como ele era pequenininho né, eu vi que a febre estava voltando já não. Dou dipirona ou novalgina. Isso. Sempre eles (médicos) recomendam ou a dipirona ou a novalgina. Nunca gostei muito de tylenol né. Eu gosto mais já da dipirona. Daí se seis horas ela voltar, ai eu me preocupo."(E8)

"É quando a febre não abaixa né. É nessa parte, porque no primeiro dia ele fica (com febre), mas não fica tanto. Aí no segundo dia ele fica né. Ai à noite aumenta. Aí a gente não dorme, a gente fica preocupado e essa coisa assim que amanhã cedo nós vamos levar né. No terceiro dia que a gente vê que pegou mesmo né. Mas tem dia que eu nem espero no terceiro dia. Porque teve um dia, eu deixei passar o terceiro dia, a médica me deu uma bronca. Ai eu falei 'não deixo mais'. No primeiro e segundo, eu já estou levando né. Ai 'não pode deixar a criança sofrer', que eles não agüentam. Ai eu falei assim 'está bom, está bom, está bom. Eu trago da próxima vez'. Ai então, eu já não deixo passar três dias. 
Dois dias mesmo eu já levo. Ontem eu percebi que ele estava com o ouvido já purgando. Eu falei assim 'Ah, amanhã eu vou levar você no médico'. Ai já fiz mesmo. Já não deixei passar muitos dias. "(E16)

Diante da necessidade de buscar atendimento para a criança, as mães se dirigiram a diferentes serviços de saúde. Os critérios utilizados pelas mães para escolha do serviço foram muito diversificados, fundamentalmente pautados em suas experiências anteriores e nas questões relacionadas a acesso.

A maioria delas utilizou os serviços hospitalares. Justificaram-se dizendo que as unidades básicas disponibilizavam apenas atendimento previamente agendado ("consulta marcada") e que, sendo doença aguda infantil um evento não previsto, o atendimento não seria possivel. Já os pronto-socorros e pronto-atendimentos hospitalares se destinam a este tipo de assistência eventual e, por esta razão, foram escolhidos nessas situações de adoecimento infantil.

"Quando está muito mal eu procuro mais é pronto-socorro. Prontosocorro não, médico né, hospital. (...) Porque no posto não dá para atender né. Só se tiver consulta marcada. Eu vou no hospital mesmo."(E2)

"Porque eu acho lá o melhor hospital do mundo e é também o hospital que tem mais perto da minha casa, é atrás da minha casa. Então, não tinha porque sair de lá, desse hospital, que é perto da minha casa para ir para outro mais longe. Tem que ir para lá mesmo. (levou para hospital) Porque lá é urgência e aqui não. (quando o estado da criança piorou) Era noite, três horas da manhã que ela aperriou."(E9)

“É mais fácil né quando ele está doente porque você chega no hospital eles sempre cuidam mais né. Assim, pelo menos na USP (Hospital Universitário), quando você va,i se a criança está doente, eles vão ter um cuidado né. Mas se é só para tratamento normal assim, para acompanhamento, eles já não aceitam né. Seria só no postinho mesmo de saúde né."(E11) 
Analisando os trechos acima apresentados constatou-se que, entre os hospitais, o mais procurado foi o Hospital Universitário (HU) da Universidade de São Paulo. Sua escolha se deu pela facilidade de estar situado próximo ao local de residência das mães, por ser uma unidade de referência do CSE e por oferecer seus serviços de pronto atendimento nas 24 horas. Isso demonstra que as mães têm clareza a respeito da lógica de funcionamento e utilização dos serviços, fazendo com que orientem sua procura de atenção de forma a obterem sucesso.

Além das razões mencionadas, algumas mães se declararam satisfeitas com esse serviço, destacando a qualidade do atendimento, traduzida pela prontidão e competência dos profissionais, e a relação de confiança estabelecida nas experiências anteriores.

"Olha, o HU eu escolho porque lá tem mais médico, tem mais opção, né. O Pronto Socorro tem bastante médico também né, eu gosto muito de lá. Mas às vezes eu prefiro porque lá tem mais opção. A gente pensa que é uma coisa e às vezes não é. Tipo minha filha, eu cheguei lá eu não sabia que era uma meningite, porque eu nunca tinha visto. Mas aí já veio aquela equipe médica: 'estamos suspeitando da meningite'. Eles foram muito rápido com ela. Eu achei assim um trabalho maravilhoso da parte deles, que eles correram mesmo né. Eu até então, eu não sabia o que estava acontecendo. Engraçado assim, que a moça estava na minha frente falou 'olha, eu vou passar você na frente'. Eu nem pedi nada para ela. Mas ali, eu estava pedindo a Deus para ver se iluminava o médico né, porque eu sabia, ela estava muito mal, com a febre muito mal, ela não agüentava andar. E ali foi tudo muito rápido. Então, isso me leva muitas vezes a procurar a USP. Por causa que lá tem mais opção se precisar de internação né. Às vezes, o Pronto Socorro está cheio, eles têm que mandar para outro hospital." (E8)

"É, eu só vou para lá mesmo né. Eu já conheço. Levo eles (filhos) desde eles pequenininhos, ganhei lá."(E19) 
Embora tenha sido bastante elogiado, o HU também recebeu criticas quanto ao atendimento prestado. Houve queixas quanto ao longo tempo de espera para o atendimento e a competência duvidosa dos profissionais do serviço.

"Só que eu não gosto muito não (do atendimento prestado no $\mathrm{HU}$ ), porque lá, além de demorar, ainda o povo sempre fala que não tem nada."(E7)

"O que mais dificulta é o horário. Tipo assim, demora muito. Você leva muito tempo ali para ser atendida. Cada trocada de plantão você leva horas ali dentro do hospital. Ai, acho que demora mais. Aqui no posto dizem que é mais demorado, eu não acho. Lá é muito mais. E, sem contar também que às vezes eles falam que é uma coisa sendo que não é, no hospital. Da última vez que eu levei ele no hospital, lá no $H U$, ele começou cansado, os olhos murchinho, 40 graus de febre. Eu levei lá no hospital, um estagiário me atendeu, disse que era só um simples resfriado. Mandou dar xarope caseiro e voltar para casa, no primeiro dia. Quando foi no segundo... Ele mandou eu voltar no sábado, aí mandou eu voltar para casa. Se por acaso ele estivesse com febre ainda, era pra mim voltar no sábado. Aí tudo bem. Quando foi na sexta-feira, ele continuou ruim, aquela febre alta, e não comia, só chorava, ele gritava. Aí eu falei assim, eu sai do serviço de manhã mesmo, peguei ele e fui no Pronto-Socorro da Lapa. Quando chegou lá no Pronto-Socorro da Lapa, uma médica de idade, ela nem examinou ele, ela só olhou e falou assim: 'mãe, o seu filho está com uma pneumonia e forte'." (E14)

Entendendo que os médicos não identificaram corretamente o problema de saúde apresentado pelo filho, subestimando-o, as mães os julgaram incompetentes. No segundo relato acima apresentado, o julgamento de incompetência profissional foi reforçado pelo diagnóstico de pneumonia efetuado por médico de outro serviço poucos dias depois, contrariando o diagnóstico de resfriado emitido antes no HU. 
Parece também ser feita uma associação entre idade e experiência profissional, sendo os mais jovens ("estagiários") vistos como menos preparados que os mais velhos. Não há dúvida de que muito se aprende através da experiência e que a idade reflete essa vantagem, mas é também verdade que se adquire muitos conhecimentos através dos estudos. Algumas vezes o profissional com idade mais avançada e maior bagagem de experiências se encontra desatualizado, em função dos rápidos progressos da ciência médica atrelados ao difícil acesso a documentos científicos por parte daqueles que prestam assistência.

Por vezes, os critérios utilizados pelas pessoas para fazer uma avaliação da competência profissional do médico não são específicos e objetivos. Então, de acordo com Boltanski (1989), avaliam a competência profissional em função de critérios difusos, abrangendo inclusive índices relativos aos modos da pessoa como boa vontade e amabilidade.

$\mathrm{Na}$ presente investigação a escolha do profissional e do serviço foi feita ao acaso, prevalecendo os critérios de acesso, o geográfico e o funcional.

No trecho que se segue, observa-se que diante de uma conduta não intervencionista, a mesma mãe pôs em dúvida a competência do profissional. Emerge a idéia de que para cada doença há um medicamento específico para tratá-la e que a intervenção medicamentosa é a melhor abordagem para todos os problemas de saúde.

"Se eu levo num hospital e não é aquilo que eu acho que eu estava achando, eu levo no outro hospital para ter a certeza, entendeu. Que nem, quando ela era novinha, ele estava... não foi ele não, foi ela com estomatite. Eu levei no Hospital Universitário, o médico falou que para aquela doença dela não existia remédio. Aí eu falei assim: 'não?' Mas eu já ouvi comentário dos filhos da minha vizinha que tinha esse mesmo problema. Ai foi passado o remédio: água bicarbonatada e Hexomedine para relaxar né, ficar dormente a boca. Tudo bem. Ai quando ela teve, levei no hospital, no Hospital Universitário falaram que para a doença 
dela não tinha remédio. Eu falei assim 'não, não tem como', hoje em dia todas doença tem um remédio. Não tem que cura, mas tem aquele que alivia. Ah, então está bom. Eu fui, peguei ela, levei lá no Pronto Socorro da Lapa. Aí uma médica que tinha lá, ela passou água bicarbonatada para fazer limpeza bucal, limpar toda boquinha, nos cantinhos da boca. Depois pingar Nistatina, aí ela podia cuspir. Aí, por último, passar Hexomedine, que era para adormecer a boca para ela conseguir comer alguma coisa. Não dar nada quente, sempre coisas gelada, tipo sorvete, mingau, uma papinha, entendeu. E lá eles passaram esses 3 tipos de remédio para ela. Já no hospital, não tinha para o tipo da doença dela. E que no outro dia ela amanheceu com a boca bem limpinha já. Às vezes o Hospital Universitário engana. Não confio. Quando eu vejo que uma coisa é grave, eu não confio naquele que diz que não é nada. Eu já me tiro pelo caso dele, que ele quase morreu." (E14)

O referido entendimento materno se deve a uma cultura intervencionista vigente na atualidade, proposta pelo modelo biomédico de assistência à saúde. De acordo com Vilela (1996), este modelo de assistência curativa por excelência privilegia o uso sistemático do medicamento como arma para o combate aos problemas de saúde.

Assim, quando a avaliação médica não resulta em intervenção, situação raramente encontrada, o cliente tem suas expectativas não atendidas. Como conseqüência disso, ocorre o fenômeno de peregrinação dos usuários pelos serviços, até que sintam seus anseios correspondidos através da obtenção de uma prescrição medicamentosa. No trecho que se segue tem-se um exemplo claro disso.

O transporte coletivo utilizado no deslocamento até o serviço se constituiu dificuldade materna para a busca de atendimento à criança no HU. Há queixas relacionadas à longa espera pela chegada do veículo e à distância que tem que ser percorrida a pé entre o ponto de parada de ônibus mais próximo e a entrada do hospital. Nas situações em que não se pode 
despender tanto tempo no deslocamento, resta às mães pedir auxilio aos vizinhos.

“É, porque eu pego ônibus assim e quando não dá para mim vim de ônibus, eu venho de carro assim dos meus vizinho. Eles me trazem. É que eu não tenho carro, então né eles me ajuda. "(EI)

"Para o hospital, aqui o HU, somente carro para ser mais fácil, mas como a gente não tem carro, vou de ônibus mesmo. Desço ali na Corifeu e subo a pé. Mas no caso de emergência assim mesmo, a gente tem que dar um jeito né. Mas no caso dele não foi emergência, fui de ônibus mesmo. "(E8)

"O dificil do HU é isso. É dificil. Na semana, não é tão demorado, mas tipo final de semana ou feriado é demorado, geralmente é trinta minuto. Na semana, de vinte em vinte minuto ele (transporte coletivo) passa. As vezes, no feriado é até mais de trinta minuto. Porque dai, eles são poucos ônibus que circulam né. E para onde eu moro, não tem muitos ônibus que possam me levar até a Corifeu (avenida próxima do serviço). Somente o Boa Vista. E da Corifeu eu subo de pé, porque não tem ônibus. Por isso que é dificil. "(E8)

Parece inacreditável, mas ainda hoje a população enfrenta problemas de fácil solução como esse, que dificultam sobremaneira seu acesso aos serviços de saúde. Bastaria uma iniciativa do setor público no sentido de rever os trajetos percorridos pelos veículos de transporte coletivo na área. $A$ dificuldade de acesso geográfico, ainda que não seja impeditiva para a utilização do serviço de saúde, é um fator limitante para a população usuária. Felizmente ainda se pode contar com a solidariedade de alguns.

Discutindo sobre o acesso da população à saúde, o Documento da OPAS (1978) enfatiza que oferta ou prestação de serviços é mais do que simplesmente a existência dos mesmos. Unglert et al. (1987) acrescenta dizendo que é preciso assegurar a acessibilidade aos serviços no sentido mais amplo do termo, que compreende as abordagens geográfica, financeira, cultural e funcional. Neste estudo, as mães entrevistadas 
declararam encontrar dificuldades de acesso aos serviços em termos geográficos (tempo e distância a percorrer para obter atendimento) e funcionais (horário de funcionamento do serviço).

A atividade de trabalho da mãe pode representar um obstáculo à busca de atendimento ao filho doente, pois restringe sua disponibilidade e acaba retardando sua ida ao serviço de saúde, como relatam duas mães (E7 e E14).

"É que agora eu estou trabalhando, então eu tenho que esperar a mulher chegar para pegar os filhos dela, para mim poder correr com essa (filha). Agora, quando eu tenho alguém que eu posso deixar no meu lugar para trazer ela no médico, eu trago. Eu já coloco um lá e venho correndo. Porque ninguém gosta de trazer ela, porque é dificil né. Eles fazem muita pergunta, as coisas, e não é todo mundo que está acostumado para responder né. Pode conviver junto mas não sabe o que é que está passando direito." (E7)

"Porque tipo assim, ele começou a ficar cansado, cansadinho, só chorava, não queria comer e os olhos dele bem murchinho. Ai eu já percebi que ele não estava bem. Ai eu peguei ele e já levei no hospital. Só que ai também, eu estava trabalhando, eu não pude levar ele no mesmo dia. Eu levei ele com dois dias depois. E, no hospital também, se você leva a criança com primeiro dia de febre, eles falam que não é o correto. Tem que esperar três dias com febre para saber o que a criança tem. Ai eu já levei já no terceiro dia. Aí fizeram raio-X e mostrou que era pneumonia mesmo."(E14)

A inserção da mulher no mercado de trabalho guarda um duplo aspecto. Por um lado, seus rendimentos advindos da atividade remunerada de trabalho incrementam o orçamento familiar, trazendo maior acesso aos bens necessários à família e, desse modo, melhoram suas condições de vida. Por outro, coloca a mulher em situação de indisponibilidade para os assuntos da casa e dos filhos, ao menos parcialmente, refletindo-se na atenção dispensada a ambos. 
No último trecho de discurso acima citado, o argumento da recomendação médica quanto à espera de três dias antes de levar a criança ao serviço serviu à mãe para justificar sua conduta e minimizar sua culpa em relação aos seus limites para o atendimento das necessidades do filho. Isto ilustra o dilema de muitas mulheres que trabalham fora de casa e, quando o filho adoece, sentem-se culpadas por não poderem dispensar a ele todo o tempo e atenção que gostariam ou que pensam que seria necessário.

Faz-se presente mais uma vez, o ideal de maternidade existente no ideário coletivo e internalizado por todos, que culpabiliza a mãe por todos os problemas existentes com os filhos. Trata-se de uma concepção perversa, que aprisiona as mulheres por um lado e as desampara por outro. Além disso, aborda a questão da saúde/doença infantil desvinculada do contexto social. 


\subsubsection{Cuidados preventivos e de promoção à saúde da criança relacionados à pneumonia}

As concepções de doença e de causalidade da doença oferecem sustentação às práticas de cuidado da criança. Assim, constatou-se que os cuidados de prevenção da pneumonia foram definidos em oposição às causas. Englobaram ações voltadas para o tratamento do resfriado e de proteção contra os agentes causais da pneumonia - frio e pó, ao lado de ações de promoção à saúde infantil de um modo geral, como alimentação adequada, higiene ambiental e imunizações.

Tendo o frio figurado como o principal fator causal das doenças respiratórias na infância, entre elas a pneumonia, cuidados voltados para evitar a exposição da criança a temperaturas baixas foram apontados por muitas mães (nove) como a estratégia mais importante na prevenção à pneumonia. Foram muitas as ações lembradas com este objetivo, quais sejam: proteger-se contra friagem e vento, não ingerir líquidos e alimentos gelados, não andar com os pés descalços, manter-se agasalhado e não brincar com água.

"Que meu filho é só mudar o tempo, que começa o narizinho. Aí a gente toma cuidado para não pegar friagem, muito vento. Daí ele melhora e graças a Deus nunca passou disso. Só a tosse."(E3)

"Se agasalhar né, andar sempre agasalhadinha e sem tomar vento, sempre com cobertor." (E12)

"Eu sempre quando está frio assim, eu agasalho bem meu filho, não deixo ele tomar vento e evito que ele fique descalço no chão. Quando está frio, eu prefiro colocar um tapete ou então deixar ele na cama."(E13)

"Tendo mais cuidado: não deixar jogado, não deixar descalço, brincar com água."(E14) 
"Não deixar a criança ficar pegando friagem, estar agasalhada, não tomar vento." (E15)

"Olha, tem gente que fala assim não tomar água gelada, não tomar muito sorvete, não deixar ficar na friagem, em época de frio principalmente né, aí agasalhar melhor. Essas coisas né que fala para gente evitar né. Assim no calor, a gente sempre acaba deixando a criança à vontade. É deixar à vontade, mas nem demais né. Tem que controlar também. É essas parte assim né, que dizem. Nem tanto é assim, por exemplo, ela quer brincar com água, não pode deixar muito. Quer ficar muito desagasalhada, não pode deixar muito. Tipo assim no verão, na época que nós estamos entrando agora né geralmente a gente fica com aquele calorão tudo né. A criança fica um pouco sem camiseta porque nem a gente mesmo agüenta, mas quando vai chegando assim tipo um final da tarde, você já vai querer por a roupa né. É nessa parte assim. Quer tomar sorvete? Não, só um e pronto, nada mais. Quer tomar alguma coisa gelada? Nem muito quente, também nem muito gelado, no temperamento normal né. É essas parte assim. Pelo menos nas fases deles, a gente controla isso."(E16)

"É não dar gelado, não deixar andar descalço, agasalhar. "(E18)

"Não deixar a criança sem blusa né para não pegar vento assim nos peito, descalça. Talvez seja esses cuidados que eu estou falando né assim. Bom, eu não sei não. Que eu acho que no caso dela é mais assim." (E 20)

A proteção contra o frio com a finalidade de prevenir o agravamento da pneumonia também foi bastante enfatizada. A gravidade do quadro é associada ao perigo de morte da criança e gera temor nas mães. Além das ações para evitar exposição ao frio já mencionadas, estavam: banho rápido, não molhar o cabelo à noite e não tomar sereno.

"Ai, tem que ter muito cuidado com a pneumonia, tem que deixar bem agasalhado (...). E quando for dar banho, tem que agasalhar, dar banho o mais rápido possivel, senão pode aumentar né". (E1) 
"Ai, eu evitaria várias coisas né, desde sair com ela na friagem, essas coisas que prejudica muito. Então, em relação à friagem, em relação ao banho, que nem está com febre, eu dou banho, só que não pode ficar muito tempo né. Essas coisas. Acho que é mais isso, evitar o gelado. A gente já evita por natureza. A gente já evita, mas aí a gente evita mais ainda."(E4)

"É preciso sim de tratamento. Precisa né, se não acaba morrendo né. Aí, agora, não sei. Eu acho que já ouvi falar para não tomar coisa gelada né, quando tem esse problema né, e fazer o tratamento direito né. "(E6)

"É, me falaram que tinha que agasalhar muito bem, principalmente o peito e as costas. Agasalhar bastante, isso ai me falaram. "(E8)

"E gostava de dar muito banho nela assim, deixava ela dentro da banheira bastante tempo. Ali, para ela ficar ali bem aquecida né, depois eu agasalhava bem ela. O que eu sei assim é na hora do banho, não deixar tomar vento depois do banho. Ah, só isso mesmo. Não andar descalço, não molhar o cabelo à noite. "(E17)

"Ah, eu já ouvi dizer que não pode deixar a criança tomar sereno, tomar chuva, não brincar com água, não deixar ficar descalça, não deixar sem blusinha para cobrir os peitos. Já ouvi isso assim. "(E17)

"Não pode tomar gelado né, não pode sair para fora. Por causa do ar né. E gelado prejudica mais. Acho que prejudica mais, que ele fica mais doente ainda. Sei lá. Acho que é ou gelado ou mais contaminado para ela né."(E18)

"Ah, eu agasalhava, tinha cuidado, não deixava descalço de jeito nenhum."(E14)

"Não deixar a criança sem blusa né para não pegar vento assim nos peito, descalça. Foi esses cuidados assim que mais ou menos eu aprendi né. Fora isso, eu não sei." (E20)

A relação entre frio e problemas respiratórios, cujas raizes estão no pensamento hipocrático, encontra-se muito viva no universo 
representacional coletivo. Assim sendo, perpassa tudo que se relaciona à compreensão materna acerca da pneumonia, inclusive as práticas de cuidado.

Tais concepções e práticas vêm sendo transmitidas através das gerações na qualidade de "dogma", conforme demonstra o relato a seguir.

"Eu não sei se é por causa do ensinamento dos meus pais, a minha filha tem três anos e seis meses, eu jamais tiro a roupa da minha filha no vento. Ou dando banho, depois do banho, eu jamais abro a janela. Eu sempre deixo uma corrente de vento pouquíssima para depois expor, exatamente porque eu tenho medo de pneumonia. Gelado, sorvete né dona S., sorvete demais. Ela não toma refrigerante gelado. Ela não toma água gelada. Ela não tira o sapato porque eu ensino. Ela nõ tira o sapato e coloca o pé no chão frio, porque eu não gosto que faça isso. Ensinei ela ser assim. Tanto é que se ela tira o sapato, ela jamais coloca o pé fora do tapete. Sempre ela grita: 'Mamãe, você traz meu chinelo?'. Porque eu ensino para ela que a friagem com os pezinho quente, eu coloco para pegar, sentir que está quente e que se colocar em contato com o chão frio, pode dar problema. Então eu ensino tudo isso para ela. O banho, eu tenho muito cuidado. Se toma banho pé com cabeça, não coloco, mas não coloco ela exposta ao vento de forma alguma, porque eu tenho muito medo."(E5)

O tratamento do resfriado, visto como enfermidade precursora da pneumonia, recebeu destaque enquanto conjunto de medidas preventivas e compreendeu as seguintes ações: oferecer líquidos em grande quantidade, fazer inalação, instilar solução fisiológica no nariz e usar medicamentos adequados. Aqui o frio foi novamente lembrado pelas mães, mas enquanto fator que pode agravar o resfriado, dando origem à pneumonia. Por esta razão, deve-se adotar condutas rigorosas para evitá-lo segundo uma das mães (E15).

"No meu entender, eu, particularmente acho assim: tem que agasalhar bastante a criança, e quando está resfriada, dar bastante líquido. $\dot{E}$, eu 
acho assim, porque geralmente eles (médicos) falam que quando a criança está resfriada, tem que dar bastante líquido. "(E8)

"Eu sei, eu acho assim, que antes de pegar pneumonia, se estiver resfriadinho, dando inalação (a criança se recupera). Eu pingo Rinossoro nele quando eu vejo que está resfriadinho, com o peitinho um pouco cheio, para não vim a pegar pneumonia. "(E10)

A importância atribuída ao pó enquanto agente causador da pneumonia foi mínima, refletindo-se em preocupação da mesma ordem de grandeza no que se refere à proteção contra ele. Assim, apenas uma mãe (E14) apontou cuidado para evitar exposição ao pó.

"Não varrer um tapete perto da criança que prejudica mais ainda."(E14)

Além das medidas preventivas descritas acima, as mães referiram outras voltadas para a promoção à saúde infantil, que acabam por resultar em proteção à criança contra pneumonia. Dentre elas, os cuidados com a alimentação ocuparam posição privilegiada. Vale lembrar que a alimentação inadequada foi trazida como fator prejudicial à saúde da criança e, portanto, facilitador para o adoecimento por pneumonia.

A alimentação surgiu como elemento que confere força ao indivíduo e, portanto, tem o poder de curá-lo de enfermidades e de impulsionar seu desenvolvimento. Dentre os alimentos ditos forte, estavam: feijão, arroz, carne, ovo, costela.

"Uma boa alimentação é...Ó, eu não posso falar de sugestão de alimentação. Posso falar da alimentação da minha filha. Que pela manhã, normal: café, leite, pão se ela quiser, bolacha se ela quiser ou biscoito, que eu sou...Eu faço um biscoito irresistível. Se ela quiser né, e ai fica a critério dela. E o almoço: feijão, arroz, carne, salsicha ela adora, ovo, pastel né dona Maria. Ovinho de codorna ela gosta demais. $\hat{E}$, na minha casa eu não tenho costume de comer massa. Assim, lá em casa não se usa fazer lasanha, eu não gosto, eu não faço, não fui criada comendo esses negócios, não me adapto a isso. Então a minha 
alimentação é feijão, arroz, abóbora com quiabo, chuchu. É, a minha alimentação é assim, carne de panela cozida, eu prefiro ao invés de frita. Na minha casa se come costela, feijão branco com dobradinha. Então na minha casa não se usa, nós não comemos massa, eu não mexo com esse negócio. Minha alimentação é outra. Ajuda de modo geral. Tanto é que você vê que ela é uma criança esperta, falante, ela pronuncia com certeza. Ela pronuncia com certeza, ela não 'titubia', ela não fica cochilando entre dois pensamentos. Eu acho que a alimentação influencia muito nisso." (E5)

Os alimentos foram apresentados organizados em pares opostos: "fortes/fracos", "bons (nutritivos)/ruins (sem valor nutritivo)". Assim, as frutas, verduras, leite materno foram considerados nutritivos e, portanto, recomendáveis às crianças, enquanto que os doces e as massas, alimentos sem valor nutritivo, devem ser evitados. Tal conhecimento se encontra em conformidade com o discurso científico.

"Uma boa alimentação, acho que ajuda né. (Boa alimentação é) Depende da criança né. No caso dele só leite do peito então né, não tem muito assim. Mas eu acho que uma alimentação saudável né, dando fruta assim para criança que pode né, já comendo bem assim né, verdura, essas coisas."(E11)

"Ah, alimentação: frutas, verdura, não besteira, que nem doce essas coisas de vez em quando né. Alguma fruta. "(E12)

De acordo com Loyola (1984), o sistema de classificação popular dos alimentos é organizado em torno de pares de oposição, tais como: "pesado/leve", "forte/fraco", "quente/frio". Os alimentos tidos como "fortes" e "pesados" dão sustentação, são nutritivos e proporcionam sensação de plenitude quando ingeridos. E são valorizados exatamente em função desses atributos.

Além da alimentação, as imunizações e a higiene ambiental foram citadas como medidas de promoção à saúde que, em seu conjunto, atuam protegendo a criança contra as doenças em geral. 
"A minha filha furou o pé com prego esses dias brincando no quintal. Se ela fosse uma criança que a mãe não tivesse os cuidados, com a carteira em dia e todas as vacinas, dai podia acarretar uma série de problemas né. Quer dizer, um cuidado puxa outro cuidado né. (..) Não só a alimentação, como higiene, e uma série de coisas. Higiene é fundamental né, é indiscutivel. Banheiro. Em primeiro lugar, banheiro. Lixo exposto de forma alguma. O lixo da cozinha tem que estar sempre no lugar onde tem que estar. Misericórdia! Não só (protege a saúde) da I. Misericórdia, (protege) de um modo geral, de um modo geral. "(E5)

Proporcionar atenção, afeto e conforto é entendido como cuidado relevante para a saúde infantil. A criança é apreendida como ser frágil e dependente, e por essa razão, requer cuidados mais freqüentes e diversificados.

“(Cuidar bem é) Ter mais atenção, cuidar. Ver se ela não está sentindo nada, ver se ela está boa. Brincar, que eles têm que brincar bastante, conversar com ela. Sabe, fazer ela dar risada, ficar o máximo possível com ela. Acho que é isso né, que eu fico bastante tempo com ela. "(E1)

"Mas eu sei que tem que proteger bastante. (Proteger é) Olhar, cuidar, é dar carinho, fazer tudo, porque eles são ainda muito pequenininho e não sabem fazer nada ainda por eles né. Então a gente tem que fazer por eles e por nós também né." (E1)

Tais cuidados dirigidos à pessoa, e não à doença ou ao corpo, constituem-se uma dimensão assistencial que extrapola a proposta do modelo biomédico.

Assim como nas causas da pneumonia, os cuidados maternos receberam ênfase, pois se interpõem entre a criança e os fatores que causam a pneumonia, representando a possibilidade de proteção infantil contra os mesmos. Novamente, a mãe é trazida como principal provedora dos cuidados infantis, sendo-Ihe atribuída tanto culpa pela ocorrência de doenças como mérito pela manutenção da saúde do filho. 
"Ah, não sei, não. Eu acho que é mais o acompanhamento da mãe mesmo né. Está sempre vendo a criança, o que a criança está fazendo, não deixar com os outros assim que você não tem idéia do que está acontecendo com ela. E você cuidando acho que evita um pouco, se você cuidar bem." (E 12)

"Ah, acho que para proteger acho que tem que ser as mãe. As mãe têm que tomar cuidado, têm que ver bem. "(E17)

No discurso reproduzido abaixo, o papel materno é engrandecido de tal forma que a mãe é investida de um poder, que a torna capaz de evitar ou combater todo e qualquer fator que possa afetar a saúde de seu filho. Emerge uma noção de onipotência materna, como se o status de mãe the conferisse poderes sobrenaturais. À "boa mãe", dedicada e empenhada no cuidado dos filhos, nada é impossivel.

"Acho que assim se a mãe cuida bem da criança, ela não pega pneumonia nem fica doente assim. Não tem nenhum tipo de doença nem nada, se cuidar bem. "(E1)

Essa concepção idealizada da mãe está embasada no pensamento rousseauniano e vem orientando a atribuição de papéis do homem e da mulher no interior da família. À mulher cabe a responsabilidade pela sobrevivência e educação dos filhos, incluindo os cuidados à saúde da criança no domicílio.

Apenas duas mulheres (E2 e E4) relativizaram o alcance da atuação materna na promoção e recuperação da saúde infantil, lembrando os limites humanos no exercício das funções maternas. Uma delas (E2) vai adiante e equipara as forças do profissional médico aos poderes divinos, afirmando serem estas duas as únicas entidades aptas a evitar o adoecimento infantil.

"Aliás, só Deus e médico né (podem proteger a criança contra pneumonia). Quem pode fazer isso né, que a gente como mãe não dá."(E2) 
"Proteger assim não. A gente evita, mas a gente não pode falar que a criança não vai ter (pneumonia). A gente não pode porque ninguém garante."(E4)

Esta mãe (E2), conferindo ao médico e a Deus tais poderes, evidencia uma postura fatalista em relação à doença que a isenta de responsabilidade e desvincula o processo saúde-doença das condições materiais de vida e de trabalho dos indivíduos. Tal postura é encontrada em comunidades cujas organizações sociais são bastante primitivas.

É preciso ressaltar que a primeira fala acima citada é de autoria de uma mãe (E2) cujo filho já adoeceu por pneumonia. Nesse caso, a atribuição de responsabilidade à figura do médico e o reconhecimento de seus limites na qualidade de provedora dos cuidados infantis pode vir ao encontro da necessidade de se justificar, isentando-a de culpa.

Entretanto, culpabilizando ou não a si mesma, ao médico e a Deus, a mãe mais uma vez nega a importância do social enquanto condicionante do processo saúde-doença. 


\subsubsection{Cuidados à criança com pneumonia no domicílio}

Nessa parte do trabalho, são apresentadas as práticas de cuidado domiciliar voltadas para a recuperação da criança com pneumonia.

O grupo de mães cujos filhos tiveram pneumonia e não foram hospitalizados (5), quando indagadas a respeito do tratamento dispensado à criança, foi unânime em referir a administração de medicamentos em casa. De início, pareciam entender tratamento como algo restrito à conduta medicamentosa.

Constatou-se que a antibioticoterapia é vista como o pilar da terapêutica domiciliar da criança com pneumonia. Todas as mães, exceto uma (E2), souberam informar o nome comercial, a dosagem e os horários de administração da droga, além da duração do tratamento.

Até mesmo essa mãe (E2) que referia desconhecer maiores informações sobre a droga oferecida ao filho, sabia que se tratava de um antibiótico. Observou-se que esta mulher se encontrava bastante confusa a respeito dos problemas de saúde apresentados pelos filhos, bem como em relação aos tratamentos realizados. Cabe esclarecer que o episódio de pneumonia infantil mais recente havia ocorrido há menos de 6 meses antes da pesquisa.

O antimicrobiano oral, de nome comercial Amoxil, apareceu como a droga eleita para o tratamento de quase todas as crianças acometidas por pneumonia.

"(a filha tomou) Aquele Amoxil né. Aquele remédio não sai de dentro da minha gaveta." (E20)

"A primeira (pneumonia) que ele (filho) teve foi Amoxil. Ai na segunda a gente tratamos com Amoxil também e foi perfeito".(E14)

Assim como as doenças e os alimentos, os medicamentos foram classificados pelas mães quanto à sua eficácia ou "força". O medicamento 
foi julgado "bom" quando se observou a recuperação do estado de saúde infantil com a remissão dos sinais de doença. Nos casos em que persistiram alguns sinais, a avaliação do medicamento foi desfavorável.

"Tem vez que o médico passa um remédio muito bom, até que as criança sara, melhora, mostra alegria e tudo. Mas tem um que o médico passa, que a criança não se dá não, com o remédio não. Não melhora bem e só sei que fica com o peito meio cheio de catarro assim. Tem médico que passa remédio muito bom." (E2)

Os depoimentos maternos sugerem que a recuperação da saúde infantil está na dependência quase que unicamente do medicamento administrado. Não há dúvida de que a indicação correta ou incorreta dos medicamentos determina em parte o resultado do tratamento. Entretanto, sabe-se que a recuperação da saúde da criança depende de um conjunto de variáveis, entre elas, a condição de saúde prévia, o agente microbiano, o momento do diagnóstico, a forma de administração da droga e a promoção do bem-estar físico e emocional da criança.

Estabelece-se uma correspondência entre doença e medicamento, entendendo-se que o tratamento de uma doença grave exige um remédio mais "forte", de utilização mais dificil e perigosa, como é o caso dos antibióticos injetáveis.

"Teve uma época, quando ela (filha) ficou ruim, ela tomava injetado né, alguma coisa. Eu acho que era Amoxil, não sei. Antibiótico. Ela ia todo dia de manhã tomar né, eu levava. E depois ela tomou em casa uns três vidros mais ou menos. "(E20)

Em se tratando de medicamento de utilização mais complexa, observou-se grande preocupação por parte das mães com o uso adequado dos medicamentos antibióticos. Reiterava-se a necessidade de serem prescritos por profissional médico e administrados de forma correta, conforme se vê nos exemplos abaixo.

"Dar os remédio bem certo como eu disse" (E1) 
"Ah, aí só os médico que dá para passar. Ai a gente tem que comprar e dar certinho." (E1)

"Dou (medicamento para redução da febre). É dipirona, novagina de infantil também né. Só isso, só dos dois que o médico passa né. Um remédio também que o médico passa também, só que eu não estou lembrada do nome."(E2)

"Bom, eu dava o remédio para eles (filhos) na hora certa, a dosagem certa"(E14)

"Dar os medicamentos certinho, na hora certa. Antibiótico né."(E20)

Tal preocupação parece ser conseqüência das recomendações médicas quanto à importância da administração adequada dos medicamentos prescritos sob pena do recrudescimento da doença. Chama a atenção que uma única mãe (E8) apresentou, ainda que de forma genérica, os fundamentos dessa ordem tão insistentemente reproduzida por elas. A informação foi fornecida a ela por uma vizinha que atua em unidade de educação infantil.

"Ela falou 'você tem que dar o remédio na hora certa para matar a bactéria, porque senão ela pode volta. Isso foi informação que eu recebi da minha vizinha." (E8)

Além de antibióticos, foi relatado o uso de medicamentos com outras finalidades, entre elas a redução da febre e a melhoria do cansaço. A administração desses medicamentos compreendeu também a via inalatória.

Todas as mulheres informaram terem cumprido o tratamento, por razões óbvias como "para tratar a doença", "para a criança ficar boa e curar a pneumonia", "porque a criança estava com pneumonia e foi o médico que passou". Em todos os casos, houve a resolução do problema infantil.

No que diz respeito ao outro conjunto de mães, composto por aquelas que nunca tiveram um filho acometido por pneumonia, a administração de medicamentos também surgiu como um fator relevante para a recuperação 
da criança doente. Dentre o rol de cuidados enumerados, foi o citado com maior freqüência pelos sujeitos da pesquisa.

Uma única mãe (E2) reportou a realização de cuidados destinados a proporcionar bem-estar emocional ao seu filho. Cabe assinalar que no discurso materno esses cuidados figuram lado-a-lado com a administração de medicamentos, considerados num mesmo nível de importância no tratamento da criança doente.

"Em primeiro lugar, põe a criança no colo para acalmar e depois se não acalmar, dar remédio para a febre e põe para dormir. "(E2)

Essa prática de cuidado é dirigida à pessoa, ou melhor, à criança e não à sua doença. Nesse sentido, constitui-se uma dimensão de cuidado que ultrapassa a assistência proposta pelo modelo biomédico, evidenciando uma abordagem de saúde/doença mais ampla. A relação entre cuidador e criança doente, vivida pelos sujeitos mãe e filho, conserva em suas raizes os laços afetivos, permitindo a expressão de uma outra dimensão do cuidado.

Conforme abordamos anteriormente, o sinal da febre é freqüentemente associado à vigência de problemas graves, trazendo consigo muita preocupação para as mães. Diante de febre alta, surge o temor da ocorrência de convulsão febril, mobilizando a mãe para a realização de medidas destinadas à redução da temperatura corporal infantil. Dentre os cuidados à criança febril encontram-se: banho morno, com ou sem adição de álcool, administração de drogas antitérmicas, hidratação e aplicação de compressas úmidas.

"E, no caso da febre, dou muito banho né, porque é bom. Ah, dou às vezes Novalgina. Remédio: novalgina, tylenol, essas coisas. Eu dou porque eu tenho medo da convulsão né. Engraçado, ela chega aos 40, ela está caída, só que ela não tem aquele... No máximo que ela já chegou é delirar, ficar delirando né. E ela chega aos 40 graus assim medido.Tem criança que com 39 está tendo convulsão né, mas ela eu dou banho geralmente, novalgina, tylenol, dipirona. É um coquetel para febre né. Para febre cada médico passa uma coisa."(E4) 
"E, em casa, além da dipirona, se está demorando... (para a febre baixar) Eu estou com o termômetro toda hora né. Se está demorando, eu aqueço um pouquinho de água, coloco álcool e dou um banho rápido e funciona, abaixa. Ou então, eu molho a fralda e coloco na testinha. Faço uma compressa." (E5)

"Ai ontem que voltou a ter febre, teve febre a noite toda. Ai como lá em casa não tinha remédio e já estava bem tarde, não tinha como eu sair, que lá onde eu moro não tem muita segurança, é perigoso, porque é favela, aí eu tive que ficar em casa. Fiquei em casa, dei banho nela morno, deixei um pouco na água, dei água para ela beber. Aí até que agora de manhã passou um pouco. "(E17)

Através dos depoimentos fica evidente que as mães dispõem de um vasto conhecimento acerca das práticas relacionada à redução da febre e se sentem aptas a implementá-lo. Possivelmente, a desenvoltura relativa ao tema é decorrente da experiência acumulada, uma vez que a febre é um evento rotineiro na infância e o conhecimento em questão está amplamente difundido na população.

Entretanto no rol dos cuidados descritos, detecta-se uma prática incorreta (banho morno com álcool), donde se pode concluir que não há espaço para resgate das práticas comunitárias nos atendimentos à criança. A falta de resgate resulta em prejuízos à criança, tanto porque as famílias podem vir a abandonar práticas apropriadas e quanto porque ela pode realizar outras incorretas.

A realização de inalação foi muito lembrada pelas mães como medida terapêutica frente à pneumonia. Era empregada com a finalidade de desobstruir as vias aéreas e facilitar a eliminação de secreções.

"Então tem que fazer tipo uma inalação para aliviar mais acho que as aveia do pulmãozinho para o ar sair e entrar mais com facilidade. "(E1)

"Inalação. Acho que seria para descongestionar né a mucosa. O catarro, eliminar. Acho que sai nas fezes né. Acho que seria isso. "(E3) 
"Quando eu vejo que está com o nariz escorrendo, cansaço, eu faço inalação. Eu acho que é bom, não sei né. Eu acho que é."(E4)

"Ai juntou as duas coisas (pneumonia e bronquite) e eles passaram também inalação com soro fisiológico, para tirar o catarro do peito. "(E8)

"E estar fazendo inalação pra sair o catarro né, do peitinho. "(E11)

"O médico mandou tomar bastante inalação" (E15)

Observa-se que uma das mães (E4) sente-se livre para decidir e executar a inalação, pois estaria apenas reproduzindo uma conduta que o profissional prescreveu anteriormente para tratar de problemas similares.

A decisão de adição de medicamentos na solução inalada remete a mãe ao carảter ilegal do ato médico que executa (a prescrição de medicamentos) e impele-a a recorrer ao especialista para legitimar sua conduta.

“Olha, cada médico para mim fala uma coisa. Só que nem, pra mim, quando eu vejo que o peito dela está chiando, o nariz dela está escorrendo né, e ela está com dificuldade de respirar, eu dou (inalação). Agora, em relação aos remédios, Berotec, essas coisas, eu fico meio confusa. Porque um fala que é para dar, outro fala que não. Então, eu nunca sei a realidade. Cada um, cada médico fala uma coisa. Agora, neste instante, estou sem inalador. Mas eu sempre dei em casa, sempre tive. O mês passado que eu devolvi, que estava comigo o inalador. Ela sempre fazia, sempre. Ah, para mim é para expectorar. "(E4)

"Ela apresentou o chiado. Ela já tem essa experiência né. Inclusive eu faço inalação na S. em casa, com Berotec, soro fisiológico. E quando eu vejo que passou de quatro inalações, eu jả procuro novamente o médico até porque eu não gosto de ficar usando Berotec sem o conhecimento médico. Porque Berotec é um medicamento fortissimo e que a gente tem que ter o máximo de cuidado. "(E5) 
“(inalação) Só com soro né. Agora, da última vez no hospital que ele tomou com Berotec né. Agora que ele esteve resfriadinho, eu coloco $5 \mathrm{ml}$ de soro fisiológico no inalador e faço. Em casa, que eu pego o aparelho emprestado da minha cunhada e faço."(E11)

"(assim como administrava os medicamentos corretamente) inalação também eu dava. A inalação eu lavava bem os recipientes. Aí eu colocava $5 \mathrm{ml}$ de soro fisiológico, 8 de Atrovent e 4 de Berotec. 8 gotas de Atrovent e 4 gotas de Berotec e $5 \mathrm{ml}$ de soro fisiológico. E dava inalação 4 vezes por dia. Por 5 dias. "(E14)

A prescrição de medicamentos à criança é percebida como uma atribuição da competência do médico. Assim, em respeito à legitimidade desse conhecimento e prática específicos, as mães sentem-se impelidas a procurar o profissional sempre que executam atos médicos sem autorização. Como diz Boltanski (1989), "ninguém tem o direito de ignorar que existe uma ciência médica, conhecimento de especialistas submetidos à lei do progresso (e) que a instituição escolar é a única com direito de transmitir".

Foi assinalado também que a prática inalatória pode ser feita não somente com o uso de aparelho apropriado, mas também através de vapor de chuveiro ou recipiente contendo água fervente. Ademais, foi relatado que a realização de tapotagem, logo após a inalação, é de grande ajuda na mobilização e remoção das secreções. A eliminação das secreções acaba facilitando a amamentação por parte da criança.

"Inalação. Só com soro em casa. Só com sorinho, $5 \mathrm{ml}$. Fazia tapotagem nas costas dela para ela soltar o catarro, para vomitar, depois da inalação." (E9)

"Você tem que dar inalação e dar uns tapinhas no peito e nas costas para eliminar. Tem inalação daqueles que dão em hospital que você compra assim o aparelhinho, ou então tem de chuveiro também. Também tem aqueles de chá assim, que você coloca, e coloca a água para ferver $e$ põe uma coisa de Vicky também dá para fazer. Aquele assim que você coloca na água e dissolve igual um chá. Tem o chá e também dá para 
você aspirar, porque tem aquele cheiro de coisa, acho que é de limão mais ou menos. Ah, dá uns tapinha. Depois de dar inalação para ajudar dá um tapinha de leve nas costas e no coisa e depois disso é mais fácil para dar de mamar, depois de um tempo. Para soltar o catarro. "(E13)

"A minha mãe ensinava né, assim para ferver né a água, deixar bem quente no vapor. Aí eu colocava ela de bruços assim né e ficava batendo né. No caso até se for olhar é a mesma inalação né, mas isso eu fazia às vezes né também. E deixava muito tempo ela no banho de chuveiro."(E20)

Ao lado da inalação, a instilação de solução por via nasal foi apresentada como estratégia tendo em vista facilitar a eliminação de secreções.

"Ou só pingar rinossoro no narizinho né, e estar fazendo inalação pra sair o catarro né, do peitinho. "(E11)

O estímulo à hidratação, à alimentação e ao aleitamento natural integraram um conjunto de práticas destinadas à recuperação da saúde da criança com pneumonia. Destacou-se que a maior aceitação de leite materno estaria contemplando duas necessidades infantis, tanto a hídrica quanto a alimentar.

"Ah, falaram para dar bastante líquido, tipo chá, suco. Isso eles recomendaram para dar bastante líquido. Eu dei chá para ele, bastante suco. Ele gosta bastante, ele não estava se alimentando direito, então ele... E mamar, que ele mama né. Ele mama no peito ainda. Mama. Ele mamou bastante, porque ele não conseguia comer comida sólida. Mas depois que ele sarou já voltou ao normal." (E8)

"Ah, mandaram, que eu me lembro, tudo assim na hora certa né, ainda dar muito líquido para ela. E na época deu até anemia nela, um monte de coisa. Eles mandava dar muita gema de ovo assim. E eu acho que isso ajudou né, para ficar mais sadia né, alimentos na hora certa." (E20) 
Proporcionar um ambiente ventilado à criança constituiu-se em mais um cuidado necessário a seu restabelecimento.

"Para deixar num lugar bastante arejado né, abrir bastante as janelas, deixar ele bastante assim à vontade, assim, lugar bem arejado, não deixar ele abafado. Porque quando ele teve a pneumonia atacou também a bronquite, tudo junto. "(E8)

Entende-se a observação criteriosa da criança pela mãe como outra prática de saúde relevante, cujo objetivo é avaliar a evolução dos sinais indicativos de doença.

"Ai, tem que ter muita atenção para isso (...) e ver as reações dela, se (a pneumonia) está voltando ou não está. "(El)

Os preparados caseiros, à base de produtos naturais como mel, frutas, gordura animal e plantas, são considerados benéficos à criança doente por apresentarem várias propriedades, que promovem alívio dos sintomas. Sua composição pode variar bastante, chegando a ser utilizada grande diversidade de ingredientes numa única fórmula de remédio caseiro.

Em geral, tanto a fórmula como o preparo se constituem parte dos costumes e práticas populares de uma determinada região. De acordo com os relatos abaixo, pode-se observar que algumas mães tomaram conhecimento de tais práticas por intermédio de seus pais,ou sogros, oriundos do interior de alguns estados brasileiros. O conhecimento em questão compõe as tradições de um grupo ou comunidade e é transmitido em familia através das gerações.

"Dar xarope de hortelã, essas coisas aí. (...) Para tosse. É. Lava o hortelã né, hortelã, poejo põe por cima, mel, essas coisa aí. Lava e coloca o hortelã com água e açúcar, mel e que mais... Não. Pouco açúcar, mais mel né e limão, alho, essas coisa aí. Cebola, sei lá... Tem gente que coloca até... deixa eu ver, manteiga por cima também, umas coisa assim que é bom, porque solta o catarro. (...) Sempre dou para ele. Às vezes, eu dou mel com limão também, que é bom. Isso ai. "(E2) 
"Tem o xarope da minha sogra só que eu não lembro, eu não lembro. Que ela faz um chá de não sei se é uma florzinha pequenininha que dá sempre no mato, mas eu não lembro, eu sou péssima para decorar. Sei que chá de hortelã é bom, que ela faz chá de hortelã. Ela pega um chumacinho com a mão, coloca na água, um pouquinho de açúcar. Ele toma que é uma beleza e é bom né. Quando ele estava com resfriado. Dou na parte da noite para não tomar vento né. Ai dorme e acorda até melhorzinho. Muito bom."(E3)

"Minha mãe fala que solta o catarro viu e eu acredito na minha mãe. Eu esquento a banha de galinha na colherzinha, passo para uma xícara $e$ depois eu pingo e faço uma massagem. Ela já até sabe disso. A S., quando ela vê eu com a colherinha, ela já deita e eu já faço a massagem nas costas, e depois dou palmada (nas costas), bato com a mão assim (em concha). Na frente e atrás, nas costas, e bato nas costinha. "(E5)

"Chá. Ai, é mel, é tanta coisa. É com leite né, melagrião. Aí eu fervo tudo com alho, cebola. Sabe assim, como fica aquele caldo grosso assim. Depois ela dá suco né, e com o caldo lá da laranja, aí mistura tudo. Aí depois ele vai fervendo, ele vai fervendo, e ele vai ficando grosso né. E aquilo lá eu dou pra ela. Tanto que de vez em quando ela toma. De vez em quando assim né. Todo dia. Quando ela está assim né. Só um pouquinho assim. Quando eu vejo que ela está tossindo né, aí eu dou assim como se fosse um mel né, assim de vez em quando. Aquelas colherzinhas pequenas, eu dou umas três vezes ao dia. Eu vejo sempre como ela fica né assim. Agora eu faço direto. Eu tenho mel puro né. A maior parte das vezes, eu dou só mel com um pingo de limão, já com medo para ela não ir já para o hospital né. Quando ela está resfriada."(E20)

Em alguns depoimentos maternos, transparece a descrença quanto à eficiência dos remédios caseiros e simpatias, revelada através da resistência materna em utilizá-los no filho. Essa cultura local tem mais força nas áreas mais distantes dos centros urbanos, onde o saber e a prática médica estão 
pouco presentes na vida da população. Nas grandes metrópoles como São Paulo, graças ao maior acesso aos serviços de saúde que se constituem os difusores por excelência do conhecimento científico, as crenças e práticas populares vêm, pouco a pouco, cedendo espaço para as concepções e condutas médicas.

Boltanski (1989) acrescenta que as mulheres parecem estar ligadas aos remédios caseiros, principalmente, pelo seu valor simbólico, pois evocam o passado, seus antecedentes, e sua origem. A utilização desse remédio não alimenta ilusões sobre seu valor de cura.

“E dou também mel. Todo dia. É porque lá em casa, na casa de mamãe, então lá meu irmão ele colhe mel, ele junta mel e minha mãe manda sempre. Eu tenho sempre mel em casa. Não é mel, não é própolis, não tem nada a ver com isso aí. É o mel tirado do mato, entendeu, que pega do mato, das abelha, coa e deixa bem purinho. Tanto é que ele vira açúcar. Se demorar, fica cristalizado. Se tiver nesse estado, eu fervo água e coloco o litro dentro. Aí ele vai voltando à consistência normal e dai eu dou sempre para ela. Eu tenho como um xarope, um expectorante. O mel tem tantas qualidades né. Não dá nem para descrever. Estar ou não (doente) para mim não interfere. Não só ela, eu também tomo, meu marido toma. Mel lá em casa é igual leite, tem sempre. Sempre, sempre, porque o mel é fundamental. Eu dou para ela também com limão, aquele limão assim pequenininho, mirim. Misturo no mel e dou. Eu já ponho direto na colher. Não, não pode ter água. Pinga o limão, mistura que fica bem grosso e já dá. Faço também chá de mel, ponho mel. Aquele que eles ensinam aqui. Põe mel, põe canela, coloca limão também. E eu dou sempre para ela. Eu tenho vontade de dar, eu vou, faço, esfrio e dou. Porque eu acredito que previne, previne um gripão, um resfriado fortíssimo. Eu acho que... Eu acho não, quem acha não sabe. Eu acredito que funciona." (E5)

Nos exemplos que se seguem, as mães relataram terem os avós da criança sugerido a utilização de remédios caseiros para ajudar na 
recuperação infantil. Entretanto, informavam não terem oferecido tais remédios aos filhos, alegando serem desnecessários. Em um dos casos (E8), declarou-se a preferência pelo uso do antibiótico para o tratamento da criança com pneumonia, evidenciando valorizá-lo pelo seu aspecto curativo.

"Não sei, muitas pessoas da antiga recomendam xaropes. Não sei, minha sogra faz uns xaropes meio com folhas assim, que ela diz que é bom, mas eu graças a Deus não precisei usar. Faz, faz. Ela usa... Eu não lembro os nome, eu não lembro. É um monte de folhinhas que ela pega e vai fazendo. Ai, sai um melado, até que fica gostoso, mas eu nunca precisei usar. (é usado) Para o catarro mesmo, para mucosa, o peito quando está cheio ajuda. Quando a criança tosse sai tudo. Sai, solta bastante. Fica forte. "(E3)

"Meu pai me sugeriu. Ele mora lá em Minas né. Eu liguei para ele, ele falou: 'Filha dá para ela'. Ele fala matruz com leite ou folha de sabugueiro, mas eu não dei não. É uma planta né. É uma planta medicinal né. Matruz com leite, bater no liqüidificador, ou a folha de sabugueiro com leite. Só que eu não dei. Ah, eu fiquei assim, meio assim... Eu sei que eles, que o pessoal assim, mineiro, nordestino assim, eles usam muito né. Mas eu achei assim que é muito ruim para tomar e ele já estava já no tratamento com Amoxilina, eu não dei nada não. Para tomar. Deve ser muito forte né. Eu achei muito forte assim o gosto. Como ele é bebezinho né... Porque nós assim, o pessoal de Minas do interior, não tem facilidade de ter médico que nem aqui tem. Então a gente se trata com remédio caseiro. Só que o matruz, a gente já usava ele para verme, essas coisas. Minha mãe fazia doce, fazia batido com leite. O sabugueiro, eu conhecia ele para catapora, para sarampo, mas para isso aí não. Mas ele me informou e eu fiquei em dívida né. Mas eu não cheguei a dar não. Fiquei com o remédio que o médico passou mesmo." (E8)

" $E$, já ensinaram simpatia para o meu menino na rinite e eu até esqueci o que é que foi que ensinaram. Acho que castanha, para mim queimar a 
castanha. Eu não fiz essa daí não. Eu não gosto de fazer simpatia, não. "(E19)

Cabe lembrar que a crença nas práticas populares não significa uma rejeição à ciência médica, porque não são coisas antagônicas.

A prática popular é mais abrangente na sua abordagem ao indivíduo, considerando-o como pessoa e contemplando todas as suas dimensões (psicológica, social, ecológica). Sua perda de espaço para as práticas médicas é lamentável, à medida que as pessoas ficam reduzidas à sua condição física e submetidas ao ritual intervencionista do atual modelo.

A prática materna é fortemente marcada pela prática médica, onde predominam elementos do modelo assistencial biomédico. Esse modelo é alicerçado numa visão biologicista e mecanicista de saúde (e doença), resultando numa prática de cunho curativo, que privilegia o medicamento como instrumento de intervenção por excelência.

É essencialmente imitativa, pois reproduz gestos e palavras do médico dentro do limite daquilo que the foi possivel captar e memorizar. De acordo com Boltanski (1989), caracteriza-se por não estar baseada num conhecimento propriamente dito, ou melhor, num conjunto de princípios que a fundamente e explique. Assim, para cuidar da criança com pneumonia, as mães se satisfazem em saber que pneumonia se trata com Amoxil, não importando qualquer informação sobre a natureza da doença ou a composição e atuação do medicamento.

Mesmo quando a mãe não leva a criança para atendimento, o médico permanece ordenando a conduta materna ainda que indiretamente, porque ela (mãe) se atém a reproduzir as recomendações médicas feitas para tratar problemas semelhantes em experiências anteriores. Resumindo, Boltanski (1989) afirma que as práticas familiares são apenas "a imitação das práticas médicas legítimas, tomadas em seu valor imediato".

Assim sendo, a prática materna apresenta apenas resquicios das práticas de medicina popular, representados por algumas poucas receitas de preparados caseiros à base de plantas e produtos naturais, transmitidas por 
parentes e amigos. Os remédios caseiros têm seu valor mais pelo aspecto simbólico que pelo curativo, constituindo-se um recurso para as mães evocarem o passado, seus familiares, sua origem. Os verdadeiros remédios, imbuidos de valor de cura, são os prescritos pelo médico.

Assim, nas concepções maternas de pneumonia identifica-se a presença de vários elementos tomados da ciência médica, apresentados de forma fragmentada, desarticulada e desprovida de seu sentido original, não permitindo uma compreensão mais clara e aprofundada acerca da doença, minimamente suficiente para embasar as práticas de cuidado à criança doente.

Revela-se então uma prática materna coerente com as limitadas concepções maternas acerca da pneumonia, uma vez que é essencialmente imitativa da prática médica e, portanto, é desprovida de conhecimentos que a fundamentam. Não havendo um corpo de conhecimentos que dê sustentação à prática, esta se apresenta frágil e ineficaz muitas vezes.

Exemplificando: as mães sabem apenas que a pneumonia é tratada com antibiótico de nome comercial Amoxil e que se não for dada a droga à criança, esta poderá piorar ou até morrer. Porém às mães não é esclarecida a etiologia microbiana da doença nem tampouco o que vem a ser um antibiótico. Então, embora tenham recebido orientação para administrar o medicamento à criança por 7 dias, elas interrompem seu uso tão logo observam remissão dos sintomas infantis (febre), pois lhes faltam as informações que explicam a doença e a prática. Assim, tendo sido a prática descontinuada antes do tratamento se completar, ela resulta ineficaz acarretando danos à criança além de resistência microbiana. Trata-se de um exemplo fictício, mas que ilustra a dinâmica das interações entre concepções e práticas, materna e médica.

Assim sendo, é primordial que a explicação do que constitui o princípio do remédio prescrito ou da recomendação enunciada seja oferecida às pessoas durante o atendimento. Conforme Boltanski (1989), percebe-se que há uma intenção educativa na medicina, mas esta educação é feita de 
forma autoritária, à medida que se recusa a transmitir às pessoas os princípios que fundamentam as prescrições, privilegiando o uso de estratégias de culpabilização da mãe e sanções, conforme se pode observar no exemplo apresentado. 


\section{CONCLUSÕES}

A opção metodológica adotada na presente investigação permitiu o alcance dos objetivos propostos, possibilitando compreender as concepções e práticas maternas relacionadas à criança com pneumonia.

O conhecimento materno sobre pneumonia é essencialmente prático e baseado nas experiências com a doença, vividas pessoalmente ou observadas entre pessoas próximas e nos discursos dos médicos que os trataram.

Entretanto, os discursos das mães cujos filhos foram acometidos por pneumonia não se diferenciaram qualitativamente das demais, sem experiência. Isto se deve ao fato de suas concepções reproduzirem em grande medida o senso comum, não tendo a experiência modificado substancialmente seu conhecimento.

De um modo geral, o grupo de mães de crianças que tiveram pneumonia apresentava baixo nivel de escolaridade (no máximo nível primário) e baixa renda familiar mensal. Quatro das seis mulheres deste grupo residiam em favelas no distrito do Rio Pequeno que, comparativamente ao Butantã, reúne população em condições menos favorecidas. Assim sendo, entende-se que as precárias condiçōes de vida das mães condicionaram tanto os agravos de saúde infantis quanto suas concepções acerca da pneumonia, que se revelaram limitadas, distorcidas e vagas.

A pneumonia é compreendida a partir do enfoque biomédico e, portanto, fortemente calcada no biológico. Tal abordagem reduz a doença a um mau funcionamento orgânico, localizado numa parte do corpo (os pulmões), perdendo-se de vista o ser humano como um todo. Fatores naturais, principalmente $o$ frio, surgem como principais agentes determinantes da doença. Esta concepção tem suas raizes no pensamento hipocrático, predominante no senso comum ainda hoje. 
É vista como uma doença perigosa, que pode levar a criança a óbito. Vislumbra-se possibilidade de cura para a criança enferma, que demanda cuidados para tanto. Os cuidados são entendidos como devendo ser realizados pela mãe, considerada o ser ideal para tal função (ideal rousseauniano de maternidade).

No processo de construção do conhecimento materno, elementos fragmentados, desarticulados e desprovidos de seu sentido original são tomados do discurso médico, não permitindo a construção de um discurso elaborado acerca da pneumonia. Conclui-se que as concepções maternas incorporam elementos da ciência médica, ainda que de forma distorcida e parcial, que convivem com outros provenientes do saber social.

A busca de atendimento em serviço de saúde foi citada como ação relevante diante do reconhecimento de sinais de doença na criança. As mães se mostraram aptas a reconhecerem diversos sinais clinicos de doença. Entretanto, mediante o reconhecimento de sinais de adoecimento infantil, não compreendem a necessidade de procurar atendimento imediato, o que pode comprometer as possibilidades de recuperação infantil.

Além disso, referiram diversos fatores que se constituíram em dificuldade para a busca do serviço, entre eles: longo tempo de espera para atendimento, desconfiança em relação à competência dos profissionais do serviço, ausência de transporte coletivo nas imediações do serviço e falta de disponibilidade materna para levar a criança ao serviço em função de sua atividade de trabalho.

As práticas de maternas de cuidado infantil são essencialmente imitativas, pois reproduzem aquilo que as mães podem captar e memorizar do discurso do médico, sem apresentar conhecimento que a fundamente e explique. Dado seu enfoque biomédico, são predominantemente de cunho individual e curativo, voltadas quase que exclusivamente para os aspectos físicos do problema. Sendo assim, elas se tornam muitas vezes pouco efetivas. 
Práticas que pertencem ao universo dos costumes e tradições populares, como remédios caseiros preparados à base de produtos naturais, coexistem de forma pálida com as práticas medicalizadas. Aos remédios caseiros atribui-se valor mais simbólico que de cura, pois evocam lembranças da família e de seu local de origem. Os medicamentos prescritos pelo médico são vistos como os verdadeiros remédios.

Assim, o presente estudo trouxe contribuições no que se refere às crenças e práticas maternas relacionadas à criança com pneumonia, que vêm subsidiar atividades educativas na área da saúde infantil. De acordo com OPAS (1997) "para ser efetiva, a educação em saúde deve ter por base um entendimento exato do conhecimento, das crenças e das práticas prevalentes na comunidade". Há que se considerar o conhecimento e o comportamento dos sujeitos em relação à saúde visando reforçar condutas corretas e corrigir as outras.

A medicina tradicional tem uma intenção educativa, porém adota uma postura autoritária. Essa concepção de educação responsabiliza e culpabiliza o individuo por seus problemas de saúde e se limita a mudar condutas de risco (Pereira et al. 2000).

Sua superação e, conseqüente, conversão a um papel libertador e problematizador constitui-se um importante instrumento para a mudança. Para mudar, é preciso ampliar, ou melhor, superar a base conceitual do atual enfoque. Segundo Nájera, apud Vilela (1996), é preciso desmedicalizar nossa forma de conceituar saúde.

Nota-se na atualidade um movimento de mudança de paradigma ainda que sutil. Aos poucos o conceito reducionista e cartesiano vai cedendo lugar a uma concepção mais abrangente, que concebe saúde não apenas como ausência de doença, mas como prática cotidiana de vida. De acordo com Vilela (1996), nessa nova concepção, "as ações de saúde não devem ficar restritas à oferta de serviços médico-hospitalares à população, mas deverão contemplar, sobretudo, a atuação intersetorial a nível dos determinantes de saúde". 


\section{REFERÊNCIAS BIBLIOGRÁFICAS}

Amofah GK, Essegbey IT, Opoku SA, Oduro J. Intended response of caretakers of pre-school children to acute respiratory infection in a rural district in Ghana. East African Med J 1995; 72(10): 619-22.

Antuñano FJL. Epidemiologia das infecções respiratórias agudas em crianças: panorama regional. In: Benguigui $Y$, Antuñano FJL, Schmunis G, Yunes J, editores. Infecçōes respiratórias em crianças. Washington (DC): OPAS; 1998. p.3-22. (OPAS. Série HCTIAIEPI-1.P)

Aung T, Tun KM, Thinn K, Thein AA. Knowledge, attitudes and practices of mothers on childhood acute respiratory infections (ARI). Southeast Asian J Trop Med Public Health 1994; 25(3): 590-3.

Badinter E. Um amor conquistado: o mito do amor materno. Rio de Janeiro: Nova Fronteira; 1985.

Bardin L. Análise de conteúdo. Lisboa: Ediçōes 70; 1977.

Benguigui Y. Controle das infecções respiratórias agudas. In: Benguigui $Y$, Land S, Paganini JM, Yunes J, editores. Ações de saúde materno-infantil a nivel local: segundo as metas da cúpula mundial em favor da infância. Washington (DC): OPAS; 1997. p.101-37. (OPAS. Série HCT/AEIPI-4)

Benguigui $Y$. Magnitude e controle das IRA em função das metas da cúpula mundial em favor da infância. In: Benguigui $Y$, Antuñano FJL, Schmunis $G$, Yunes J, editores. Infecções respiratórias em crianças. Washington (DC): OPAS; 1998. p.23-41. (OPAS. Série HCTIAIEPI-1.P)

Berlinguer G. Medicina e política. $3^{a}$ ed. São Paulo: HUCITEC; 1987.

Boltanski L. As classes sociais e o corpo. $3^{\mathrm{a} e d .}$ Rio de Janeiro: Graal; 1989. 
Brioschi LR, Trigo MHB. Familia: representação e cotidiano. Reflexões sobre um trabalho de campo. São Paulo: CERU; 1989. (Col. Textos, $2^{\mathrm{a}}$ série, $n^{\circ} 1$ )

Campbell H, Byass $P$, Greenwood BM. Acute lower respiratory infections in Gambian children: maternal perception of illness. Ann Trop Paediatr 1990; 10(1): 45-51.

Campos MS. Poder, saúde e gosto: um estudo antroplógico acerca dos cuidados possiveis com a alimentação e o corpo. São Paulo: Cortez; 1982.

Capra F. O ponto de mutação. São Paulo: Cultrix; 1987. O modelo biomédico; p. 116-55.

Charaly MDM. Resultados de estudos etnográficos em relação ao controle das IRA na Bolivia. In: Benguigui $Y$ et al., editores. Infecções respiratórias em crianças. Washington DC: OPAS; 1998.

Chevallier E. Importância do trabalho sobre as representações na formação dos agentes sanitários e sociais. Rev Bras Crescimento Desenvolvimento Humano 1993; (1): 160-2.

Chiesa AM, Bertolozzi MR. Estudo epidemiológico da mortalidade por infecçōes do aparelho respiratório em menores de 5 anos da região do Butantã, São Paulo, Brasil. In: Benguigui Y, editor. Investigações operacionais sobre o controle das infecções respiratórias agudas (IRA). Washington (DC): OPAS; 1997. p. 19-29.

Chiesa AM. A eqüidade como princípio norteador da identificação de necessidades relativas ao controle dos agravos respiratórios na infância. São Paulo; 1999. [Tese de Doutorado - Faculdade de Saúde Pública da Universidade de São Paulo]

Chiesa AM, Veríssimo MDLO. A educação em saúde na prática do PSF. In: Instituto para o Desenvolvimento da Saúde. Universidade de São Paulo. Manual de enfermagem. Ministério da Saúde. Brasilia: Ministério da Saúde; 2001. 
Cleland JG, van Ginneken JK. Maternal education and child survival in developing countries: the search for pathways os influence. Soc Sci Med 1988; 27(2): 1357-68.

Collett CA, Pappas DE, Evans BA, Hayden GF. Parental knowledge about common respiratory infections and antibiotic therapy in children. South Med J 1999; 92(10): 971-6.

Costa JF. Ordem médica e norma familiar. $3^{\mathrm{a}}$ ed. Rio de Janeiro: Edições Graal; 1989.

Denno DM, Bentsi-Enchill A, Mock CN, Adelson JW. Maternal knowledge, attitude and practices regarding childhood acute respiratory infections in Kumasi, Ghana. Ann Trop Paediatr 1994; 14(4): 293-301.

Diaz HRH. Resfriado comum. In: Benguigui Y, Antuñano FJL, Schmunis G, Yunes J, editores. Infecções respiratórias em crianças. Washington (DC): OPAS; 1998. p. 169-82.

Ejzenberg B, Fernandes VO, Rodrigues Neto AJ, Baldacci ER, Grisi SJFE, Bellizia Neto $L$ et al. Pesquisa de etiologia bacteriana em 102 crianças internadas com o diagnóstico de pneumonia aguda. Pediatria (São Paulo) 1986; 8(2): 99-106.

Franco MLPB. O "estudo de caso" no falso conflito que se estabelece entre análise quantitativa e análise qualitativa. Cad Educ 1986a; (6): 32-41.

Frederico Neto F. Pediatria ao alcance dos pais: compreender a doença é o melhor remédio. $2^{\mathrm{a}}$ ed. Rio de Janeiro: Imago Ed.; 2000. Febre; p.7193.

Fundação IBGE. Censo demográfico 2000: características da população e dos domicilios - resultados do universo. Rio de Janeiro; 2001.

Fundação IBGE. Pesquisa nacional por amostra de domicílios 1999: síntese de indicadores. Rio de Janeiro; 2000.

Fundação IBGE. Tabulação avançada do censo demográfico 2000: resultados preliminares da amostra. Rio de Janeiro; 2002. 
Fundação SEADE. Pesquisa de condições de vida no Estado de São

Paulo: 1998. Disponivel em <URL: http://www. seade.gov. br/cgi-

bin/pcrv98/pcv_01.ksh>. [2002 Jul 10]

Gil AC. Métodos e técnicas de pesquisa social. $4^{a}$ ed. São Paulo: Atlas; 1994.

Gomes FMS, Valente MH, Margarida Filho H, Paes EC, Tanaka CM, Passos LD et al. Incidência de infecções respiratórias agudas em crianças do Centro de Saúde Escola "Professor Samuel B. Pessoa", São Paulo, Brasil. In: Benguigui $Y$, editor. Investigações operacionais sobre o controle das infecções respiratórias agudas (IRA). Washington (DC): OPAS; 1997. p.917. (OPAS. Série HCTIAIEPI-2)

Gomes FMS, Valente MH. Pneumonias. In: Valente MH, Gomes FMS, organizadores. Assistência à criança sob risco de infecção respiratória aguda: normas do ambulatório. São Paulo; 1999. [Manual do Centro de Saúde - Escola "Prof. Samuel B. Pessoa" ].

Gouveia AJ. Professores de amanhã: um estudo de escolha ocupacional. $2^{\mathrm{a}}$ ed. São Paulo: Pioneira; 1970.

Grace J. The treatment of infants and young children suffering respiratory tract infection and diarrhoeal disease in a rural community in Southeast Indonesia. Soc Sci Med 1998; 46(10): 1291-1302.

Graham, NM. The epidemiology of acute respiratory infections in children and adults: a global perspective. Epidemiol Rev 1990; 12: 149-78.

Hudelson P, Huanca T, Charaly D, Cirpa V. Ethnographic studies of ARI in Bolivia and their use by the National ARI Programme. Soc Sci Med 1995; 41(12): 1677-83.

Iyun BF, Tomson G. Acute respiratory infections - mother's perceptions of etiology and treatment in south-western Nigeria. Soc Sci Med 1996; 42(3): 437-45. 
Khamgaonkar MB, Kulkarni AP, Naik DB, Masare S. Awareness of urban slum mothers regarding home management of diarrhoea and symptoms of pneumonia. Indian J Med Sci 1999; 53(7): 316-8.

Khan AZ, Tickoo R, Arif T, Zaheer M. Mothers' attitudes to children's chest infections in India. J R Soc Health 1995 oct; 115 (5): 314-7.

Lane STM. Linguagem, pensamento e representações sociais. In: Lane STM, Codo W, organizadores. Psicologia social: o homem em movimento. $2^{\mathrm{a}}$ ed. São Paulo: Brasiliense; 1985. p.32-9.

Loyola MA. Médicos e curandeiros: conflito social e saúde. São Paulo: DIFEL; 1984.

Luz MT. Natural, racional, social: razão médica e racionalidade científica moderna. Rio de Janeiro: Campus; 1988. A disciplina das doenças e a razão social: categorias médico-sociais no século XIX; p. 83-116.

Martins J, Bicudo MAV. A pesquisa qualitativa em psicologia. São Paulo: Moraes/EDUC; 1989.

Maynard-Tucker G. Parents' management of ARI in the region of Marrakech. J Trop Pediatr 1998 Feb; 44(1): 59-62.

Mendes AB, Catarin AL, Kusumoto A, Silva AP, Kuraoka AM, Mendes CMS et al. Doenças respiratórias: em busca da prevenção. Semina 1995; 16 (ed. especial): $73-80$.

Minayo MCS, organizador. Pesquisa social: teoria, método e criatividade.

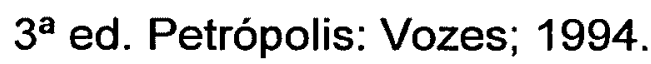

Minayo MCS. O desafio do conhecimento: pesquisa qualitativa em saúde. São Paulo: HUCITEC/Rio de Janeiro: ABRASCO; 1992.

Ministério da Saúde. Fundação Nacional de Saúde. Mortalidade Brasil: 1995. Brasília: CENEPI; 1998.

Ministério da Saúde. Secretaria de Assistência à Saúde. Coordenação Materno-Infantil. Assistência e controle das infecções respiratórias agudas. $4^{\mathrm{a}}$ ed. Brasília (DF); 1994. 
Monteiro Al, Enders BC, Mota EAF. Promoção de saúde da criança no seio familiar: uma estratégia de cuidar das infecções respiratórias agudas [resumo]. In: Livro Programa do $2^{\circ}$ Encontro Internacional de Pesquisa em Enfermagem: trajetória espaço-temporal da pesquisa; p.196. 2002 out 28-31; Águas de Lindóia, Brasil. São Paulo: Escola de Enfermagem da USP; 2002.

Mossé C. As lições de Hipócrates. In: Le Goff J. As doenças têm história. Lisboa: Terramar; 1985. p. 39-55.

Moura D. Saúde não se dá: conquista-se. São Paulo: HUCITEC; 1989.

Muhe L. Mothers' perceptions of signs and simptoms of acute respiratory infections in their children and their assessment of severity in an urban community of Ethiopia. Ann Trop Paediatr 1996; 16(2): 129-35.

Murray J, Adeyi GN, Graeff J, Fields R, Rasmuson M, Salgado R, Sanghvi T. Ênfase comportamental na saúde materno-infantil: focalizando o comportamento das pessoas que cuidam de crianças (pais e encarregados da educação para o desenvolvimento de programas de saúde materno-infantil nas comunidades. Arlington (EUA): Basics; 1997.

Naspitz CK, Carneiro-Sampaio MMS, Sampaio PL. Alergia respiratória: asma brônquica e rinopatia alérgica. In: Marcondes E, coordenador. Pediatria básica. São Paulo: Sarvier; 1987. p. 672-8.

Nunes AS. A medicina social e a questão feminina. Physis Rev Saúde Coletiva 1991; 1(1): 49-76.

Oliveira $A B$. A evolução da medicina até o início do século $X X$. São Paulo: Pioneira/Secretaria de Estado da Cultura; 1981. Medicina da antiga Grécia; p. 59-91.

Organizacion Panamericana de la Salud. Extension de la cobertura de servicios de salud con las estrategias de atencion primaria y participacion de la comunidad. Washington DC; 1978. (Documentos oficiales, 156) 
Organização Panamericana da Saúde, Organização Mundial da Saúde, Fundo das Nações Unidas para a Infância. Apresentação e análise do Curso sobre Atenção Integrada às Doenças Prevalentes na Criança (AIDPC): versão preliminar. 1996 nov. (OPS/HCP/HCT/ARI/CDD/96.31)

Organizacion Panamericana de la Salud, Organizacion Mundial de la Salud. Infecciones respiratorias agudas en los niños. Washington (DC); 1985. (OPAS/OMS - Publicación Científica, 493)

Pebley A, Hurtado E, Goldman N. Beliefs about children's illness. J Biosoc Sci 1999; 31(2): 195-219.

Penna HAO. Febre. In: Marcondes E, Sucupira ACSL, Saito MI, Dias MHP, coordenadores. Pediatria em consultório. São Paulo: Sarvier; 1988. p.223232.

Pereira IMTB, Penteado RZ, Marcelo VC. Promoção da saúde e educação em saúde: uma parceria saudável. Mundo da Saúde 2000; 24(1): 39-44. Prefeitura de São Paulo. Secretaria de Implementação das Subprefeituras. Administração Regional do Butantã. Base de dados: administração regional do Butantã - 2001. São Paulo; 2001.

Prefeitura de São Paulo. Secretaria Municipal da Família e Bem-Estar Social. Supervisão Regional de Serviço Social do Butantã. Subunidade Regional de Informações Técnicas. Estudos da área regional do Butantã: aspectos demográficos e renda. São Paulo; 1984. (Série Informações, $\left.n^{\circ} 4\right)$

Querido MJS. Butantã e suas veredas: guia cultural e turístico. São Paulo: RQ Regina Querido; 1999.

Ribeiro TVM. Bronquite. In: Marcondes E, coordenador. Pediatria básica. São Paulo: Sarvier; 1987. p. 1380-2.

Richardson RJ, Peres JAS, Correia LM. Pesquisa social: métodos e técnicas. São Paulo: Atlas; 1985. 
Rimé B. Lenguage y comunicación. In: Moscovici S. Psicología social. Barcelona: Paidós; 1986. p.535-571.

Rocha JM, organizador. Compêndio de pediatria e puericultura. Rio de Janeiro: Ed. Capitólio; 1951. v.2.

Rodriguez AEP, Comesna JPG, Pordeus AMJ, González JB, Jaime AA. Actitudes y practicas de madres o tutores frente a las infecciones respiratorias agudas. Rev Cubana Pediatr 1990; 62(5): 666-77.

Roque AIV, Canalejo HM. Nivel educacional de las madres y conocimientos, actitudes y prácticas ante las infecciones respiratórias agudas de sus hijos. Rev Panam Salud Publica/Pan Am J Public Health 1999; 6(6): 400-7.

Rozov T. Pneumopatias agudas. In: Marcondes E., coordenador. Pediatria básica. São Paulo: Sarvier; 1987. p.1388-99.

Ruvinsky R, Balanzal MC. Pneumonias bacterianas e virais. In: Benguigui $Y$, Antuñano FJL, Schmunis G, Yunes J, editores. Infecções respiratórias em crianças. Washington (DC): OPAS; 1998. p.217-51.

Ryan GW, Martinez H, Pelto GH. Methodological issues for eliciting local signs/symptoms/illness terms associated with acute respiratory illness. Arch Med Res 1996; 27(3): 359-65.

Sá CP. Representações sociais: o conceito e o estado atual da teoria. In: Spink MJ, organizador. $O$ conhecimento no cotidiano: as representações sociais na perspectiva da psicologia social. São Paulo: Brasiliense; 1993. p.19-45.

Sposati AO, coordenador. Mapa da exclusão/inclusão social da cidade de São Paulo. São Paulo: EDUC; 1996.

Sposati AO, Koga D, coordenadores. Cartografia da exclusão/inclusão social das crianças e adolescentes na cidade de São Paulo. São Paulo: PUC; 1996. 
Tamayo RP. El concepto de enfermidad: su evolúción a través de la historia. México (DF): Fondo de Cultura Económica; 1988. La teoría humoral de la enfermedad; p. 93-154.

Teka T, Dagnew M. Health behaviour of rural mothers to acute respiratóry infections in children in Gondar, Ethiopia. East African Med J 1995; 72(10): 623-5.

Toro JA, Pereda CF, Astroza EULP, Risopatrón F. Conocimientos, creencias y praticas de las madres en infecciones respiratorias agudas y traumatismos infantiles. Ministerio de Salud del Chile/UNICEF; 1992.

Triviños ANS. Introdução à pesquisa em ciências sociais: a pesquisa qualitativa em educação. São Paulo: Atlas; 1987.

Unglert CVS, Rosenburg CP, Junqueira CB. Acesso aos serviços de saúde: uma abordagem de geografia em Saúde Pública. Rev Saúde públ 1987; 21(5): 439-46.

Urday JAGF, Guevara RP, Fuentes CMP, Pérez AP. Antibioticoterapia de las infecciones respiratorias agudas en niños menores de 5 años. $2^{\mathrm{a}}$ ed. Lima: Editorial Universitaria; 2001.

Van Ginneken JK, Lob-Levyt J, Gove S. Potencial interventions for preventing pneumonia among young children in developing countries: promoting maternal education. Trop Med Int Health 1996; 1(3): 283-94. Varella D. Olhe esse vento nas costas, menino! Folha de São Paulo 2002 jun 15; cad llustrada: 12.

Varella F. Os segredos ocultos em cada espirro. Revista Veja 2002 jun 12; 1755: 62-3.

Velho G, organizador. Desvio e divergência: uma crítica da patologia social. $5^{\mathrm{a}}$ ed. Rio de Janeiro: Jorge Zahar Editor; 1985. O estudo do comportamento desviante: a contribuição da antropologia social; p. 11-28. Veríssimo MDLÓR, Sigaud CHS. Assistência de enfermagem à criança com agravos respiratórios. In: Ministério da Saúde, Universidade de São Paulo, 
Instituto para o Desenvolvimento da Saúde. Manual de Enfermagem: Programa Saúde da Família. Brasília; 2001. p. 95-8.

Vilela EM. Desmedicalizando o conceito de saúde. Ribeirão Preto; 1996. [Dissertação de Mestrado - Escola de Enfermagem de Ribeirão Preto da USP].

Yunes J, Díaz A. Situação da saúde materno-infantil e suas tendências na América Latina e no Caribe. In: Benguigui Y, Land S, Paganini JM, Yunes J, editores. Ações de saúde materno-infantil a nível local, segundo as metas da cúpula mundial em favor da infância. Washington (DC): OPAS; 1997. p.1-16. (OPAS. Série HCT/AIEPI-4)

Zioni Gomes F, Adorno RCF. Crescimento e desenvolvimento na prática dos serviços de saúde: revisão histórica do conceito de criança. Rev Saúde públ 1990; 24(3): 204-11. 


\section{ANEXO 1 \\ ROTEIRO DA ENTREVISTA}

$N^{\circ}$ entrevista:

Data:

Duração:

\section{PARTE}

A pergunta abaixo permite diferenciar as mães quanto à experiência de ter tido um filho com pneumonia com idade de 2 meses a 4 anos.

1. Algum filho teve pneumonia com idade de 2 meses a 4 anos:

$\operatorname{sim}$

não

\section{PARTE}

A) Caracterização das mães

1. Nome:

2. Idade (em anos):

3. Endereço completo:

4. Nome e data de nascimento dos filhos:

5. Situação conjugal: separada

6. Religião:

7. Escolaridade materna:

8. Ocupação materna (descrever a atividade de trabalho realizada, se em casa ou fora de casa, se remunerada):

casada/vive junto com pai da criança solteira

evangélica outra: anos de estudo completos 
9. Quem é o chefe da familia:

10. Escolaridade do chefe: anos de estudo completos

11. Ocupação do chefe (descrever a atividade de trabalho realizada, se em casa ou fora de casa, se remunerada):

12. Renda Familiar Mensal (perguntar sobre os rendimentos de todos os moradores da casa - salários, aluguéis, pensões, e somá-los):

Rendimentos:

B) Caracterização da criança e da conduta materna relacionada ao episódio de pneumonia mais recente de seu filho

1. Nome da criança:

2. Idade da criança quando teve pneumonia (anos e meses):

3. Faz controle de saúde periódico da criança: $\operatorname{sim}$ não

Se não, porque:

Se sim, última consulta: Data:

Profissional:

Serviço:

4. Vacinação da criança está em dia:

$\operatorname{sim}$ não

5. Durante este último episódio de pneumonia, a senhora procurou atendimento para seu filho em serviço de saúde: $\operatorname{sim}$ não

6. Recebeu atendimento: $\operatorname{sim}$ não

Se não, porque:

Se sim: Data: Profissional:

Serviço: 
7. Qual foi o tratamento recomendado:

8. O tratamento foi cumprido: $\operatorname{sim}$ não Porque:

9. Durante este episódio de pneumonia da criança, a senhora procurou ajuda em outro local ou junto a outras pessoas: sim não Porque:

Se sim, qual(is):

10. Quais foram as recomendações feitas:

11. As recomendações foram seguidas: $\operatorname{sim}$ não Porque:

12. Seu filho precisou ficar hospitalizado para se recuperar da pneumonia: $\quad \operatorname{sim}$ não

Se $\operatorname{sim}$, porque: 


\section{PARTE}

Esta parte da entrevista deve ser conduzida de forma não-diretiva, visando a oferecer máxima liberdade de expressão aos sujeitos sobre a temática estudada. A fim de aprofundar alguns aspectos e facilitar a manifestação dos entrevistados sobre os mesmos, devem ser formuladas perguntas abertas sobre os tópicos expostos abaixo, caso ainda não tenham sido abordados pelas mães. Cabe ressaltar que nem todos os tópicos devem ser estimulados para $\circ$ grupo de mães cujos filhos nunca tiveram pneumonia, pois se referem à experiência de cuidar e tratar de uma criança com pneumonia.

- Elenco das doenças respiratórias (ou de pulmão) conhecidas

- Definição, sinais e sintomas, e causas de pneumonia

- Fatores que contribuem para ocorrência de pneumonia infantil (fatores pré-disponentes ou desencadeantes)

- Fatores que protegem a criança contra pneumonia (fatores de proteção)

- Tratamento e cuidados domiciliares realizados à criança com pneumonia

- Trajetória de procura de atendimento à criança em serviço de saúde e fatores determinantes (facilidades e dificuldades)

- Fontes de obtenção das informações fornecidas

Nesta última etapa, a pesquisadora deve fazer as três perguntas relacionadas a seguir. A resposta da primeira questão deve ser registrada e a partir dela devem ser formuladas as demais, mencionando os sinais referidos um a um separadamente. 
1. Na sua opinião, quais sinais e sintomas estão presentes quando uma criança apresenta doença respiratória?

2. Na presença de (citar sinal) a senhora procuraria atendimento para seu filho em um serviço de saúde?

3. Depois de quantos dias na presença de (citar sinal) a senhora levaria seu filho ao serviço de saúde? 


\section{ANEXO 2 \\ Termo de Consentimento Livre e Esclarecido}

Prezada Senhora (nome da mãe da criança),

Meu nome é Cecilia Helena de Siqueira Sigaud e sou pesquisadora. Estou desenvolvendo um estudo com o objetivo de compreender o conhecimento das mães sobre pneumonia e o cuidado das crianças doentes em casa.

Para isso, devo entrevistar algumas mães de crianças menores de 5 anos. Cada entrevista levará aproximadamente 30 minutos de duração. Para facilitar o registro das informações, peço sua permissão para gravar a conversa. Depois, as informações serão analisadas por mim e comprometome a não revelar a identidade dos participantes na apresentação do relatório final da pesquisa.

A senhora tem total liberdade de recusar ou retirar seu consentimento a qualquer momento da pesquisa, sem que isso implique em qualquer prejuizo para o atendimento de (nome da criança) neste serviço.

Caso deseje saber mais informações sobre o estudo, a senhora poderá entrar em contato comigo pelo telefone 3066-7602, na Escola de Enfermagem da USP.

Gostaria de participar?

Declaro que consinto em participar do presente Protocolo de Pesquisa depois de ter sido convenientemente esclarecida pelo pesquisador e ter entendido o que me foi explicado, a respeito do objetivo, da forma de participação e da utilização das informações na pesquisa sobre o conhecimento das mães e o cuidado das crianças com pneumonia em casa, além da liberdade de participar ou retirar meu consentimento a qualquer momento sem qualquer prejuizo para o atendimento de meu filho.

São Paulo, de de 2001.

Assinatura do Sujeito da Pesquisa:

Assinatura da Pesquisadora: 